\author{
Luiza Paschoal Stein
}

\title{
Morfodinâmica e eventos de sobrelavagem: praias da baía de Santos, SP
}

\begin{abstract}
Dissertação apresentada ao Instituto Oceanográfico da Universidade de São Paulo, como parte dos requisitos para obtenção do título de Mestre em Ciências, Programa de Oceanografia, área de concentração Oceanografia Geológica.
\end{abstract}

Orientador:

Prof. Dr. Eduardo Siegle

São Paulo

2018 


\title{
UNIVERSIDADE DE SÃO PAULO INSTITUTO OCEANOGRÁFICO
}

Morfodinâmica e eventos de sobrelavagem: praias da baía de Santos, SP

\author{
Luiza Paschoal Stein
}

Dissertação apresentada ao Instituto Oceanográfico da Universidade de São Paulo, como parte dos requisitos para obtenção do título de Mestre em Ciências, Programa de Oceanografia, área de concentração Oceanografia Geológica.

Aprovada em _ I I I

Versão Corrigida

Prof. Dr. Eduardo Siegle

$\operatorname{Prof}(\mathrm{a}) . \operatorname{Dr}(\mathrm{a})$.

$\operatorname{Prof}(a) . \operatorname{Dr}(a)$. 


\section{Sumário}

1 Introdução 1

1.1 Introdução Geral . . . . . . . . . . . . . . . . . . . . . . 1

1.2 Estrutura da Dissertação . . . . . . . . . . . . . . . . 2

2 Embasamento Teórico 3

2.1 Sistema Praial . . . . . . . . . . . . . . . . . . . 3

2.2 Morfodinâmica Praial . . . . . . . . . . . . . . . . . . . . . . 4

2.3 Ondas na Região Costeira . . . . . . . . . . . . . . . . . . . . . . 4

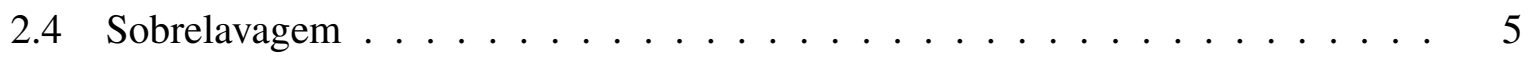

3 Objetivos $\quad 7$

4 Área de Estudo $\quad 8$

4.1 Caracterização da Área de Estudo . . . . . . . . . . . . . . . . . . . 8

4.2 Formação Geológica e Características Geomorfológicas . . . . . . . . . . . . . 10

4.3 Meteorologia . . . . . . . . . . . . . . . . . . . 10

4.4 Características Oceanográficas . . . . . . . . . . . . . . . . 11

5 Morfodinâmica e Modelagem de Ondas 13

5.1 Introdução . . . . . . . . . . . . . . . . . . . . . . . . . 13

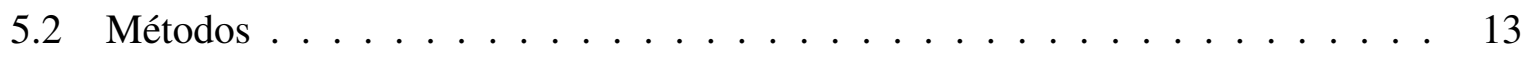

5.2.1 Levantamento de Campo . . . . . . . . . . . . . . . . . 13

5.2 .2 Regime de Ondas . . . . . . . . . . . . . . . . . . . 16

5.2 .3 Modelagem Numérica . . . . . . . . . . . . . . . . 17

5.2 .4 Deriva potencial . . . . . . . . . . . . . . 19

5.2 .5 Força de onda . . . . . . . . . . . . . . . . 20

5.3 Resultados . . . . . . . . . . . . . . . . . . . 20

5.3 .1 Deriva potencial ..................... 20

5.3 .2 Força de onda . . . . . . . . . . . . . . 27

5.3 .3 Morfologia . . . . . . . . . . . . . . . 32

5.4 Discussão . . . . . . . . . . . . . . . . . . . 50

6 Eventos de Sobrelavagem $\quad 55$

6.1 Introdução . . . . . . . . . . . . . . . . . . . . . . 55

6.2 Métodos . . . . . . . . . . . . . . . . . . . 55

6.2 .1 Sobrelevação $\mathrm{o}_{\text {onda } \ldots \ldots \ldots \ldots \ldots \ldots \ldots \ldots} \ldots \ldots$

6.2 .2 Sobrelavagem . . . . . . . . . . . . . . 57

6.3 Resultados . . . . . . . . . . . . . . . . . . . 58

6.4 Discussão . . . . . . . . . . . . . . . . . . . . . . . 70 
7 Considerações Finais e Conclusão $\quad 73$

7.1 Considerações Finais . . . . . . . . . . . . . . . . . . . . 73

7.2 Conclusão . . . . . . . . . . . . . . . . . . . . . 74

Referências $\quad 76$ 


\section{Lista de Figuras}

2.1 Terminologia da divisão dos subambientes praiais ( $\lambda$ representa o comprimento de onda). Adaptado de Tessler e Mahiques (2000). . . . . . . . . . . . . . . 3

4.1 Localização da área de estudo (Imagem: Google Earth). . . . . . . . . . . . . 8

5.1 Ilustração da correção ortométrica aplicada nos dados retirada do site do IBGE (2016) . . . . . . . . . . . . . . . . . . . 15

5.2 Imagem indicando os 5 setores nos quais a praia de Santos foi dividida e os 3 setores da praia da Itararé (As linhas pretas separam os setores). As linhas azuis indicam os perfis extraídos de cada setor e os pontos vermelhos onde foram extraídos os resultados da modelagem numérica. . . . . . . . . . . . . . 16

5.3 Grade usada para a modelagem numérica no Delf3D módulo Wave. Essa grade também foi usada para a interpolação da batimetria usada na modelagem. . . .

5.4 Localização dos pontos onde foram extraídos os resultados do da modelagem numérica, indicados na grade modelada. . . . . . . . . . . . . . . 18

5.5 Deriva potencial anual da praia de Santos para os 12 pontos. . . . . . . . . . 21

5.6 Idem a Figura 5.5, mas indicando a deriva potencial sazonal em Santos. A linha de setas mais próxima a costa representa o verão, seguida do outono, do inverno e da primavera consecutivamente.

5.7 Deriva potencial referente à semana anterior de cada levantamento realizado em Santos para os 12 pontos no ano de 2015. . . . . . . . . . . . . . 23

5.8 Idem a Figura 5.7, mas para os levantamentos de 2016. . . . . . . . . . . . . 24

5.9 Deriva potencial anual da praia de Itararé para os 6 pontos. . . . . . . . . . . 25

5.10 Idem a Figura 5.9, mas indicando a Deriva Potencial Sazonal em Itararé. A linha de setas mais próxima à costa representa o verão, seguida do outono, do inverno e da primavera consecutivamente.

5.11 Deriva potencial referente à semana anterior da cada levantamento realizado em Itararé para os 6 pontos no ano de 2016 . . . . . . . . . . . . . . 27

5.12 Força de onda média anual (W/m) ao longo do arco praial da baía de Santos. . . 28

5.13 Série temporal da Força de Onda calculada através dos resultados de ondas do modelo Delft-3D Wave, no seis pontos de extração em Itararé no ano de 2015. .

5.14 Série temporal da Força de Onda calculada através dos resultados de ondas do modelo Delft-3D Wave, no seis pontos de extração em Itararé no ano de 2016. Nesta imagem os dias com levantamento topográfico estão indicados com uma estrela. . . . . . . . . . . . . . . . . . .

5.15 Série temporal da Força de Onda calculada através dos resultados de ondas do modelo Delft-3D Wave, no doze pontos de extração em Santos no ano de 2015. Nesta imagem os dias com levantamento topográfico estão indicados com uma estrela. . . . . . . . . . . . . . . . . . 
5.16 Série temporal da Força de Onda calculada através dos resultados de ondas do modelo Delft-3D Wave, no doze pontos de extração em Santos no ano de 2016. Nesta imagem os dias com levantamento topográfico estão indicados com uma estrela. . . . . . . . . . . . . . . . . . . . . .

5.17 Modelo digital de terreno indicando a topográfica da praia no dia do levantamento a) Santos - levantamento de 22/04/2015. b) Itararé - levantamento de 06/07/16.

5.18 (Continuação) Modelo digital de terreno, mostrando a variação na topografia, em metros, entre o primeiro e o último campo a) Santos - 2015: Entre os levantamentos de 22/04/15 e 22/05/15 b) Santos - 2016: Entre os levantamentos de 27/05/16 e 02/11/16 c) Itararé - 2016: Entre os levantamentos de 06/07/16 e 02/11/16, em metros.

5.19 (Continuação) Modelo digital de terreno, mostrando a variação na topografia, em metros, entre os campos realizados no ano de 2015 em Santos. a) Entre os levantamentos de 22/04/15 e 22/05/15. b) Entre os levantamentos de 22/05/15 e 08/06/15. c) Entre os levantamentos de 08/06/15 e 26/06/15. d) Entre os levantamentos de 26/06/15 e 22/07/15. e) Entre os levantamentos de 22/07/15 e 07/08/15.

5.20 (Continuação) Modelo digital de terreno, mostrando a variação na topografia, em metros, entre os campos realizados no ano de 2016 em Santos e em Itararé. a) Santos: Entre os levantamentos de 27/05/16 e 06/07/16. b) Santos: Entre os levantamentos de 06/07/16 e 26/08/16. c) Santos: Entre os levantamentos de06/08/16 e 30/09/16. d) Santos: Entre os levantamentos de 30/09/16 e 02/11/16. e) Itararé: Entre os levantamentos de 06/07/16 e 26/08/16. f) Itararé: Entre os levantamentos de06/08/16 e 30/09/16. g) Itararé: Entre os levantamentos de 30/09/16 e 02/11/16 . . . . . . . . . . . . . . . . . . . . . . . . .

5.21 Gráfico do volume total dos caminhamentos realizados em cada levantamento de campo em Santos, indicando o eixo y em $1 \times 10^{6} \mathrm{~m}^{3}$

5.22 Diferença de volume entre os levantamento topográficos em Santos, realizados nos anos de 2015 e 2016.

5.23 Gráfico do volume total dos caminhamentos realizados em cada levantamento de campo em Itararé, indicando o eixo y em $1 \times 10^{5} \mathrm{~m}^{3} \ldots$. . . . . . . . . .

5.24 Diferença de volume entre os levantamento topográficos em Itararé, realizados no ano de 2016.

5.25 Gráfico do volume dos setores normalizado pela área de cada um $\left(\mathrm{m}^{3} / \mathrm{m}^{2}\right)$. As cores representam as datas dos levantamento topográficos de 2015 - Santos. . .

5.26 Gráfico da variação do volume normalizado dos setores em cada levantamento no ano de 2015 - Santos. . . . . . . . . . . . . . . . . . . . . 45

5.27 Idem a Figura 5.25, mas para o ano de 2016 - Santos. . . . . . . . . . . . . . 46 
5.28 Idem a Figura 5.26, mas para o ano de 2016 - Santos. . . . . . . . . . . . .

5.29 Gráfico do volume dos setores normalizado pela área de cada um dos levantamentos em Itararé $\left(\mathrm{m}^{3} / \mathrm{m}^{2}\right)$. As cores representam as datas dos levantamento topográficos em Itararé. . . . . . . . . . . . . . . . . . . . . . . .

5.30 Gráfico da variação do volume normalizado dos setores em cada um dos levantamentos em Itararé. . . . . . . . . . . . . . . . . . . . . 48

5.31 Perfis praias dos levantamentos topográficos para cada setor de Santos. . . . . .

5.32 Perfil praial dos levantamentos topográficos para cada setor de Itararé. No setor 3 temos 2 perfis, indicando as diferenças topográficas na zona de sombra da Ilha Urubuqueçaba.

6.1 Imagem indicando os 5 setores nos quais a praia de Santos foi dividida e os 3 setores da praia da Itararé (As linhas pretas separam os setores). As linhas azuis indicam os perfis extraídos de cada setor. . . . . . . . . . . . . . . .

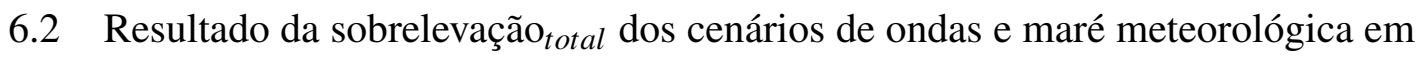
Santos no setor 1 - Altura do calçadão $=2.4 \mathrm{~m}$. A linha vermelha representa a divisão entre valores de sobrelevação ${ }_{t o t a l}$ menores e maiores que a altura do muro. 60

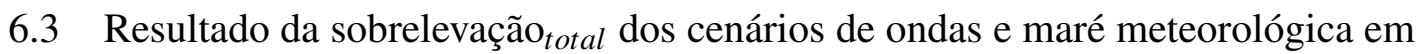
Santos no setor 2 - Altura do calçadão $=2.1 \mathrm{~m}$. A linha vermelha representa a divisão entre valores de sobrelevação ${ }_{t o t a l}$ menores e maiores que a altura do muro. 62

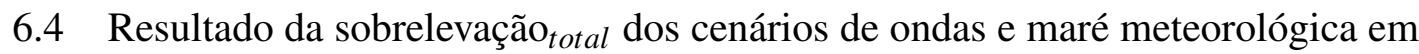
Santos no setor 3 - Altura do calçadão $=2.2 \mathrm{~m}$. A linha vermelha representa a

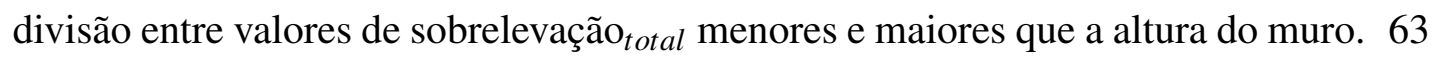

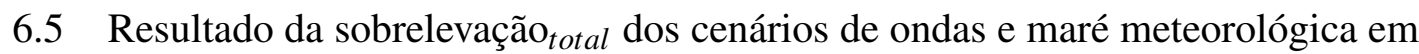
Santos no setor 4 - Altura do calçadão $=2.1 \mathrm{~m}$. A linha vermelha representa a divisão entre valores de sobrelevação ${ }_{\text {total }}$ menores e maiores que a altura do muro. 64

6.6 Resultado da sobrelevação ${ }_{\text {total }}$ dos cenários de ondas e maré meteorológica em Santos no setor 5 - Altura do calçadão $=2.3 \mathrm{~m}$. A linha vermelha representa a

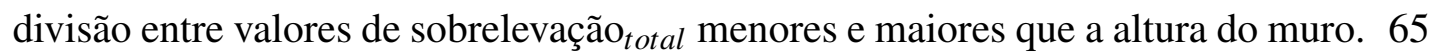

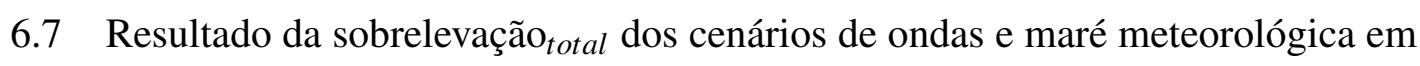
Itararé no setor 1 - Altura do calçadão $=2.2 \mathrm{~m}$. A linha vermelha representa a divisão entre valores de sobrelevação ${ }_{t o t a l}$ menores e maiores que a altura do muro. 67

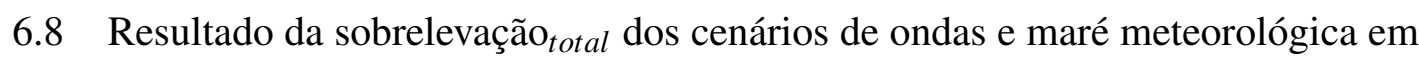
Itararé no setor 2 - Altura do calçadão $=2.2 \mathrm{~m}$. A linha vermelha representa a divisão entre valores de sobrelevação ${ }_{t o t a l}$ menores e maiores que a altura do muro. 68

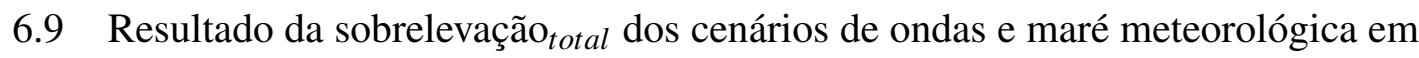
Itararé no setor 3 - Altura do calçadão $=2.2 \mathrm{~m}$. A linha vermelha representa a

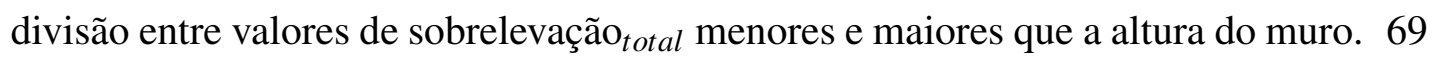




\section{Lista de Tabelas}

1 Pontos de extração dos resultados da modelagem numérica, indicando a latitude e a longitude da qual foram extraídos, assim como a profundidade de cada ponto. 19

2 Cenários de Hs e Tp usados para calcular o sobrelevação ${ }_{o n d a}$. Onde tem o ponto, indica que o Hs está associado aquele Tp. . . . . . . . . . . . . . . 56

3 Probabilidade ocorrência dos cenários de sobrelavagem, onde as colunas são os cenários de maré meteorológica e as linhas de sobrelevação ${ }_{\text {onda }}$. A tabela indica a probabilidade tanto para Maré de Sizígia quanto Quadratura, pois estes têm a mesma chance de ocorrência. Os valores mais próximos do verde tem mais chances de ocorrer do os valores em tons vermelhos. . . . . . . . . . . . 59

4 Setores de Itararé usados na análise da sobrelavagem e suas respectivas declividades. . . . . . . . . . . . . . . . . . . . 71

5 Setores de Santos usados na análise da sobrelavagem e suas respectivas alturas de muro e declividades . . . . . . . . . . . . . . . . . 71 


\section{Agradecimentos}

Primeiramente gostaria de agradecer aos meus pais, Marta e Roberto, por todo o apoio ao longo do mestrado, sempre me apoiando e incentivando. Sem vocês nada disso teria sido possível. Obrigada pelas notícias oceanográficas de revistas e jornais, pelos sábios conselhos, pelas longas conversas ao telefone e por sempre acreditarem em mim. Agradeço ao meu irmão, Gabriel, pelas cobranças de brincadeira, mas que no fundo são de verdade: "E ai, como vai a dissertação?". As minhas grandes amigas, Aline e Isadora, que sempre estiveram ao meu lado em todas as etapas da vida e me incentivaram muito nessa etapa.

Ao meu orientador, Prof. Dr. Eduardo Siegle, pela disposição em me ajudar sempre e sanar todas as dúvidas. Agradeço pela oportunidade e por aceitar me orientar mais uma vez, agora no mestrado.

Danilo, não tenho palavras para agredecer toda sua parceria. Sempre me ajudando com os levantamentos de campo, disciplinas e na própria dissertação. Agradeço principalmente pela sua paciência. Essa nossa parceria só agrega coisas boas.

Não posso deixar de agradecer aos colegas guerreiros que concordaram em me ajudar nos levantamentos de campo. Aos que andaram comigo por cerca de $20 \mathrm{~km}$ sem pausa, obrigada pela força. Espero que as cocadas e os churros tenham compensado o esforço/sofrimento.

Bruna; Pedro; Débora; Stella; Caio; Julia; Mirella; Mirela e Lilian, companheiros de laboratório, obrigada pela companhia, ajuda nos levantamentos topográficos e ajuda com os problemas da dissertação, foi fundamental para a conclusão do trabalho.

Os colegas da graduação que continuaram presentes e torcendo pelo meu sucesso: Bau; Domo; Martim; Burns; Mariana; Danilo; Camila; Ceci; Gabi; Ligia; Faísca; Otel e Paulinha, obrigada pela amizade! \#MUQATX.

Agradeço também as eternas companheiras de republica: Paulinha, Ju e Mai. Mesmo mais longe agora a família continua unida. Eu não poderia ter ido morar com pessoas melhores. Paulinha, obrigada por esses 7 anos morando juntas e enfrentando as dificuldades da faculdade juntas.

Por último e nada menos importante, minha maior família de São Paulo, o Tsunami Rugby. Meninas, vocês são demais, o nosso companheirismo dentro e fora de campo é que faz desse time tão bom! Obrigada por compreenderem (apesar de não aceitarem) minha faltas em jogos e treinos. Mais uma etapa vencida! 


\section{Resumo}

As praias urbanizadas são ambientes complexos devido à interação da ocupação antropogênica e dos processos costeiros. A ocupação costeira vem se caracterizando por alteração e deterioração da paisagem, processo mais intenso em grandes cidades litorâneas, onde casas e edifícios são construídos nas proximidades imediatas da orla. O presente trabalho analisa a morfodinâmica e processo de sobrelavagem das praias de Santos e Itararé, duas praias urbanizadas com a presença de obras na orla. Foram realizados levantamentos topográficos nas praias e modelagem de ondas (Delft 3D - Wave) para toda a baía durante os anos de 2015 e 2016. Cenários de sobrelevação ${ }_{\text {onda }}$ e nível do mar foram estipulando para o cálculo da sobrelevação ${ }_{\text {total }}$ e assim conhecer as condições que levam a sobrelavagem. A baía de Santos encontra-se aberta para sul, expondo a linha de costa para a ação de frentes frias. A variabilidade do clima de ondas, derivada das mudanças das suas condições meteorológicas formadoras, pode alterar a morfologia da praia. Em Santos e São Vicente as ondas de sul e sudeste apresentam maiores alturas de onda e são mais frequentes no outono e inverno quando temos mais frentes frias na região. Os resultados indicam relação entre a incidência de ondas com maior força de onda $(\mathrm{W} / \mathrm{m})$, associadas a frentes frias, em trechos mais inclinados das praias com perda de volume. A variedade de incidência das ondas ao longo da praia estudada mostra um decréscimo na força de onda, sendo maior em Itararé e caindo em direção a Ponta da Praia, com a presença de picos altos na Ponta da Praia. Justificando porque este trecho sofre mais variação de volume e perda de sedimento fato que pode estar associado a dragagem do canal do porto de Santos. Em ambos os trechos com maior declividade e menor faixa de areia apresentaram maior sensibilidade à ação das ondas e também maior chance de sofrer sobrelavagem, de todo o arco praial da baía de Santos a porção leste de Santos se mostrou a mais propícia a sofrer inundação.

Descritores: Morfodinâmica praial, eventos de tempestade, modelagem numérica, sobrelavagem. 


\begin{abstract}
Urbanized beaches are more complex environments due to the interaction of anthropogenic occupation and coastal processes. Coastal occupation has been characterized by alteration and deterioration of the landscape, being more intense in large coastal cities, where houses and buildings are built in the immediate vicinity of the beach border being subject to potentially high risk of erosion. The present work analyzed the morphodynamics and overwashing of the beaches of Santos and Itararé, two urbanized beaches with the presence of anthropogenic constructions in the beach border. Topographic surveys on both beaches and wave modeling (Delft 3D - Wave) were carried out for the entire basin during the years of 2015 and 2016. Wave run-up and sea level scenarios were stipulated for the calculation of the total water level and so determined conditions that lead to overwashing. The bay of Santos is open to the South, exposing the coast line for the action of cold fronts. The variability of the wave climate, derived from the changes of its formative meteorological conditions, can alter the morphology of the beach. In Santos and São Vicente, South and Southeast waves have higher wave height and are more frequent in autumn and winter when we have more cold fronts in the region. The results indicate the direct relationship between the incidence of waves with higher wave force $(\mathrm{W} / \mathrm{m})$, associated with cold fronts, with loss of volume along the beaches. The variety of wave incidence along the studied beach shows a decrease in wave force, being higher in Itararé and falling towards Ponta da Praia, in the area protected by the rocky promontory. However in Ponta da Praia we see high values of wave force, justifying why this stretch suffers more volume variation and loss of sediment, that we belive happends because of Port Channel. In both stretches with greater slope and lower sand range showed greater sensitivity to the action of the waves and also greater chance of overwash, of all the praial arc of the Santos bay, the Eastern portion of Santos was the most propitious to suffer flooding.
\end{abstract}

Key Words: Beach morphology, storm events, numerical modeling, overwash. 


\section{Introdução}

\subsection{Introdução Geral}

A zona costeira é a região de interface entre o oceano e as terras emersas dos continentes. Por esta ser uma região de transição, está suscetível a diversas condicionantes físicas que modelam a dinâmica sedimentar local. Os principais agentes modeladores se devem aos aspectos hidrodinâmicos, como a ação das ondas formadas pelo vento, a ação das correntes formadas pelas ondas e a ação das marés.

As ondas são geradas pela transferência de energia do vento para a superfície do oceano, de acordo com a intensidade, duração e direção do vento. Esta é a principal forma de entrada de energia na zona costeira, sendo responsável pela formação das correntes costeiras e também do transporte de sedimento (Komar 1998). Dessa forma as ondulações controlam a morfodinâmica costeira.

A ação das ondas na zona costeira pode causar o acúmulo de sedimento na costa formando ambientes sedimentares, chamados de praia. A definição de ambientes praias mais utilizada, foi proposta por King (1972): "As praias são ambientes sedimentares costeiros, formados, mais comumente, por areias de constituição variada, estendendo-se desde onde inicia a interferência da velocidade orbital das ondas sobre o fundo marinho, até o limite mais continental da ação das ondas de tempestade ou mudanças fisiográficas bruscas". Sendo assim cada praia possui características variadas, como forma, tamanho e composição, dependendo da fonte de sedimento local e a sua proximidade e dos processos modeladores (ondas e ventos).

Embora ocupem uma pequena porção das terras emersas do planeta, as praias são de grande importância socioeconômica e ambiental, devido a diversas atividades costeiras que são realizadas ao seu redor, como pesca, atividade portuária, lazer e outros. Segundo Komar (1998), o ambiente costeiro abriga cerca de dois terços da população mundial em uma faixa estreita adjacente à costa. No Brasil a linha de costa atinge aproximadamente $8500 \mathrm{~km}$ de extensão com um grande número de cidades, sendo áreas densamente ocupadas e de grande importância econômica. Devido à tendência social de migração para regiões costeiras e a pressão que a expansão urbana vem causando nestas áreas, nas últimas décadas surgiram muitos trabalhos visando à caracterização, dimensionamento e formas de prevenção e mitigação nestes ambientes.

As praias urbanizadas são ambientes mais complexos devido à interação da ocupação antropogênica e dos processos costeiros. A ocupação costeira vem se caracterizando por alteração e deterioração da paisagem, sendo mais intenso em grandes cidades litorâneas, onde casas e edifícios são construídos nas proximidades imediatas da orla a ponto de estarem sujeitos a risco potencialmente elevado de perda por erosão (Muehe 2001).

O crescimento demográfico sem planejamento ocupacional acarreta problemas sociais, econômicos e ambientais (Bonduki 1996). Esse é o caso dos municípios de Santos e São Vicente, tema do presente trabalho, com construções (ruas, calçadas, prédios) próximas a faixa de areia da praia, influenciando o balanço de sedimento e a hidrodinâmica local. Nestes casos, entender 
os processos modificadores da morfodinâmica praial é uma das premissas para o gerenciamento costeiro, sendo que estes são influenciados simultaneamente pelo clima de ondas, características dos sedimentos, morfologia e a hidrodinâmica.

Santos sofreu uma ocupação desordenada da orla (Bonduki 1996), que refletiu nas obras como os canais de escoamento, as avenidas, os jardins e o emissário submarino. Obras estas que geram impactos na costa tornando cada vez mais necessários estudos de monitoramento costeiro voltado para auxiliar o manejo da região e para melhor compreensão da influência do homem nesses ambientes. Estes estudos fornecem conhecimento para desenvolver medidas aplicáveis para o uso sustentável. Neste contexto, o presente estudo pretende avaliar o comportamento da morfodinâmica praial da baia de Santos e o processo de sobrelavagem sobre o muro construído ao longo de toda a extensão da faixa de areia. Apesar de a baixada santista ser uma região densamente povoada, poucos estudos foram realizados até o momento a respeito do comportamento morfodinâmico de suas praias e não existem estudos a respeito do processo de sobrelavagem nas áreas construídas das praias. Assim, os resultados aqui apresentados, em adição à melhor compreensão do funcionamento desse sistema praial, fornecem subsídios para o correto gerenciamento da região.

\subsection{Estrutura da Dissertação}

Essa dissertação apresenta resultados de uma porção de levantamentos de campos, modelagem numérica de onda e cálculo de sobrelavagem na forma de sete capítulos. Composto pela introdução (Capítulo 1), embasamento teórico (Capítulo 2), objetivo (Capítulo 3), área de estudo (Capítulo 4), morfodinâmica e modelagem de ondas (Capítulo 5), sobrelavagem (Capítulo 6), onde nos capítulos 5 e 6 são apresentados os métodos e os resultados de cada tema respectivamente. Finalizando com considerações finais, conclusão e sugestões futuras (Capítulo 7), onde as conclusões principais resultados de cada um dos dois principais capítulos são sumarizadas e são levantadas as limitações do trabalho. 


\section{Embasamento Teórico}

\subsection{Sistema Praial}

Ao longo de todo o globo os continentes possuem costas deposicionais, os chamados sistemas praiais. Onde quer que existam sedimentos e espaço para acomodação vulneráveis à ação de ondas, haverá a existência desses sistemas. Existem muitas definições formais para descrição das praias, como a definição proposta por King (1972). Outra definição é a de Short (1999): "Praias são acumulações de sedimentos depositados por ondas entre a base modal das ondas e o limite do espraiamento. Onde a base modal das ondas corresponde à profundidade máxima na qual as ondas transportam os sedimentos em direção à costa, e o limite do espraiamento corresponde ao limite subaéreo da ação das ondas e consequentemente do seu transporte de sedimentos". Essa definição ressalta a importância da presença das ondas para a formação das praias e no transporte de sedimento após sua formação. Entretanto, além dos processos associados à ação das ondas, os sistemas praiais são influenciados pela ação das marés, dos ventos, das drenagens fluviais, pelas características sedimentares, e o histórico geológico da região. Devido a todos esses fatores influenciando a evolução de um sistema praial, para facilitar os estudos desses ambientes, os sistemas praiais são divididos em subambientes de acordo com os processos atuantes. A terminologia para a divisão de tais subambientes varia nos trabalhos. Portanto, neste trabalho será usada a terminologia referente proposta por Tessler e Mahiques (2000) (Figura 2.1).

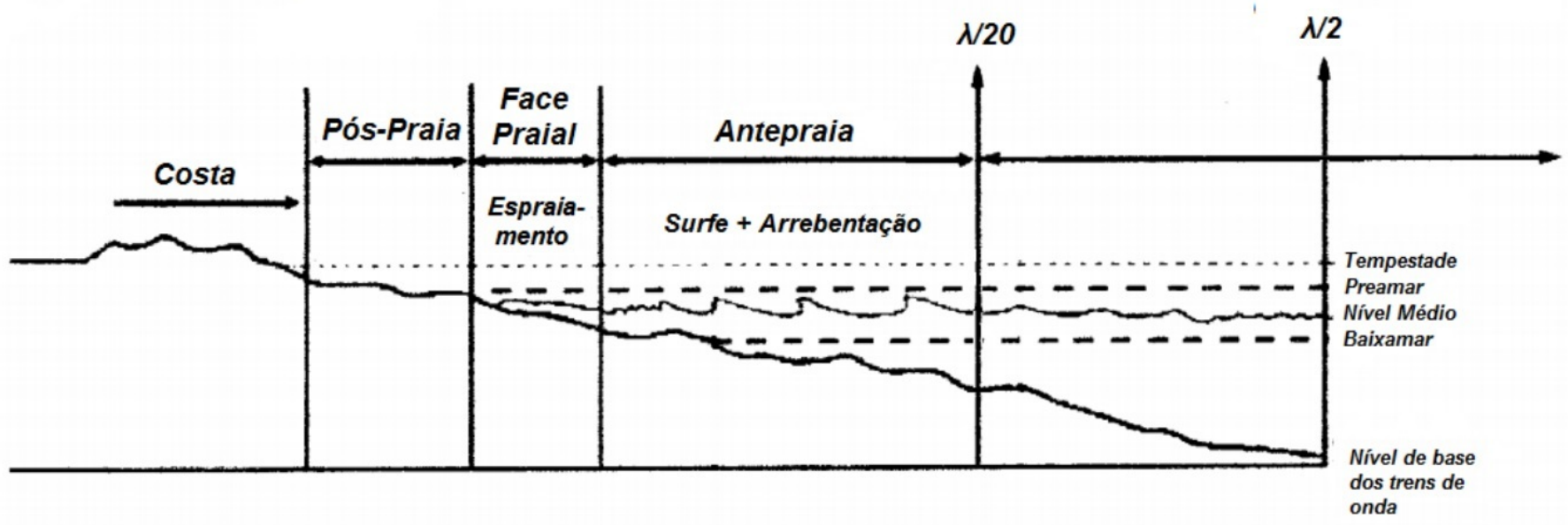

Figura 2.1: Terminologia da divisão dos subambientes praiais ( $\lambda$ representa o comprimento de onda). Adaptado de Tessler e Mahiques (2000).

O ambiente praial é subdivido em relação a sua hidrodinâmica em zona de arrebentação, zona de surf e zona de espraiamento. A zona de arrebentação se trata da porção da praia caracterizada pela ocorrência deste processo de dissipação de energia de onda sobre a praia. A altura da arrebentação da onda é limitada pela profundidade local, e a quebra da onda apenas ocorre quando a profundidade se aproxima da altura de onda (Komar 1998). 
A zona de surfe está relacionada com a dissipação de energia das ondas incidentes pela quebra de onda. Esta zona geralmente está associada à zona de arrebentação, pois é muito difícil diferenciá-las. Durante a quebra, boa parte da energia dissipada é transferida para a geração de correntes longitudinais e transversais à praia (Komar 1998).

O espraiamento acontece na região de limite entre a zona emersa e o oceano, onde ocorrem intensos processos de transporte de sedimento. Esta zona pode ser limitada pelo alcance máximo e mínimo da onda (Komar 1998).

A subdivisão dos sistemas praiais não é só hidrodinâmica, estes também podem ser divididos em subambientes de acordo com a morfologia: antepraia; face praial e pós-praia(Tessler e Mahiques 2000). A antepraia se trata da porção da praia dominada por processos de empinamento de onda e arrebentação, já a face praial é porção na qual ocorrem os processos da zona de espraiamento e o pós-praia refere-se à zona do limite superior da zona de espraiamento até qualquer mudança fisiográfica brusca.

\subsection{Morfodinâmica Praial}

Os sistemas praiais são ambientes costeiros altamente dinâmicos e suscetíveis a alterações. Sua morfologia representa o ajuste mútuo entre os processos hidrodinâmicos e topografia da região, envolvendo o transporte de sedimento (Davis e FitzGerald 2004). Em outras palavras, a morfologia praia é resultado do transporte de sedimento em conjunto com a intensidade dos processos hidrodinâmicos gerando variações temporais e espaciais, de diferentes escalas, ao longo da praia.

Morfodinâmica praial é uma abordagem na qual as observações morfológicas e dinâmicas são integradas para gerar uma descrição mais completa e coerente do ambiente praial. A hidrodinâmica existente ao longo da praia é o resultado da interação de ondas incidentes, refletidas ou parcialmente refletidas da face praial, fluxos permanentes e aperiódicos, que resultam da arrebentação e dos fluxos gerados por ondas e marés (Wright e Short 1984).

Os movimentos causados pela hidrodinâmica, fazem com a água exerça atrito sobre os sedimentos móveis da praia, gerando gradientes espaciais e temporais em seu transporte que ocasionam mudanças na morfologia. Segundo Calliari et al. (2003), conforme a hidrodinâmica produz determinadas morfologias, estas induzem mudanças no padrão hidrodinâmico atuante. A morfologia e a hidrodinâmica evoluem conjuntamente no sistema praial

\subsection{Ondas na Região Costeira}

Os processos que atuam nos sistemas praiais começam a agir na base do antepraia, na camada mais profunda, esta camada pode se estender a profundidades maiores dependendo do clima de ondas. Portanto a camada tem como limite externo a ação das ondas no fundo e interno a praia. De acordo com Calliari et al. (2003) uma das principais causas das modificações 
na praia é troca bidirecional de sedimentos ao longo desta camada através da zona de arrebentação. As ondas são em grande maioria, responsáveis pelas feições observadas nas praias.

O regime da zona de arrebentação depende do clima de ondas de águas profundas da região estudada e das modificações que as mesmas sofrem antes de atingir o ponto de quebra. Essas ondas são chamadas de ondas de gravidade geradas pelo vento, cuja força restauradora do movimento é a gravidade. As ondulações são geradas pela transferência de energia do vento para a superfície do oceano, de acordo com a intensidade, duração e direção do vento. As características do vento formador das ondas definem determinados aspectos da onda como período e altura de onda.

As variações temporais do estado da praia dependem fundamentalmente do regime de ondas de águas profundas, ao passo que, as mudanças espaciais dependem principalmente das variações na modificação das ondas à medida que as mesmas se propagam para águas rasas. Estas modificações são controladas pela geologia e configuração da costa. Quando as ondas atingem a costa e sofrem o processo de quebra na praia, dispersam energia e gerando uma porção de correntes costeiras determinando a movimentação dos sedimentos (Davis e FitzGerald 2004). A quantidade de energia de onda que chega à zona costeira é definida pelo clima de ondas da região, tornado essencial para os estudos costeiros o conhecimento sobre o regime de ondas do local.

\subsection{Sobrelavagem}

A sobrelavagem ocorre quando a superfície livre do oceano atinge uma elevação máxima que ultrapassa a altura de crista da duna praial ou outro obstáculo (Donnelly, Kraus, e Larson 2004), ocorrendo a passagem de água por cima da duna ou obstáculo. Isso acontece em caso de eventos extremos, que causam altos valores de nível da água total devido à combinação de maré astronômica, meteorológica e altura de onda. Neste trabalho a sobrelevação devido a esta combinação de processos será referida como sobrelevação ${ }_{t o t a l}$ e, a sobrelevação gerada pela onda (run-up), como sobrelevação ${ }_{\text {onda }}$.

Em praias urbanizadas, como as da baixada santista, é comum a retirada da proteção natural, como dunas, para a construção de obras e consequentemente a presença de muros para proteger a terra de inundações causadas pela sobrelavagem. A sobrelevação ${ }_{\text {total }}$ dessas estruturas devido a eventos de tempestades pode causar danos a zona costeira, a toda infraestrutura atingida e até mesmo por em risco a população local. É de interesse para a gestão costeira entender o funcionamento desses eventos perante a cada praia urbanizada, para entender o riscos e poder prever

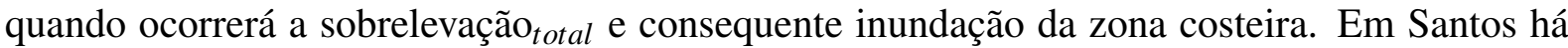
vários registros de sobrelavagem extrema que causaram avanço do mar e inundação costeira.

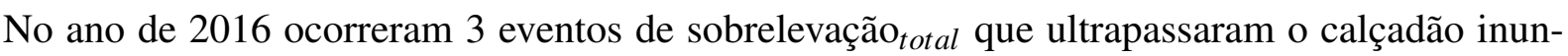
dando ruas, ciclovias e garagens de prédios ${ }^{1}$. No mês de agosto houve a combinação de maré

\footnotetext{
${ }^{1}$ Notícia G1-globo: https://goo.gl/LTwP0X; https://goo.gl/i4xFyG; https://goo.gl/fyHM5j
} 
de sizígia com altos valores de maré astronômica, altura de onda e período de pico de onda, foi a sobrelavagem mais intensa dos últimos dois anos.

Os processos de sobrelavagem correspondem a valores extremos de sobrelevação ${ }_{\text {onda }}$, e/ou extremos valores de maré meteorológica. Quando há uma combinação desses dois fatores e ainda coincidente com maré de sizígia, se têm as condições perfeitas para a ocorrência da sobrelavagem extrema, que foi o caso de agosto de 2016. Entretanto é muito mais comum a ocorrência desses fatores em separados, devido à baixa probabilidade de valores elevados serem apresentados em conjunto na natureza.

A compreensão desses eventos é importante para determinar as ações de proteção costeiras que deveram ser aplicadas. Apesar de terem vários estudos de avaliação das zonas de riscos e determinação de linhas de segurança (Healy e Dean 2000; Sallenger Jr 2000; Ruggiero et al. 2001; Ferreira et al. 2006; Raposeiro et al. 2013), o foco da sobrelavagem em praias urbanizadas ainda é pouco visto. Muitos autores desenvolveram modelos para encontrar o nível total de água que leva a sobrelevação ${ }_{\text {total }}$ de mar e inundação para o caso de dunas (Ruggiero et al. 2001; Garrity et al. 2006; Serafin e Ruggiero 2014; Stockdon et al. 2014). Mase et al. (2013) propôs uma formulação para sobrelevação ${ }_{o n d a}$ e sobrelavagem em muros costeiros construídos em terra ou em águas muito rasas, que será usado nesse trabalho, essa formulação foi aplicada com sucesso no trabalho de Silveira et al. (2016). 


\section{Objetivos}

O objetivo do presente trabalho está centrado na avaliação da evolução morfodinâmica do sistema praial da baia de Santos, a partir do acompanhamento da variabilidade morfológica, reconhecimento de tendências do transporte de sedimento e do clima de ondas locais. Esse conhecimento da morfodinâmica do sistema fornece subsídios para a avaliação da ocorrência dos processos de sobrelavagem que acontecem na região.

Os objetivos específicos são:

- Avaliar a evolução topográfica das praias ao longo da série temporal;

- Estimar a variação do volume de sedimento das praias ao longo do período estudado;

- Analisar o clima de ondas na região e sua relação com os aspectos morfológicos;

- Reconhecimento de tendências do transporte de sedimento ao longo das praias;

- Avaliar os pontos da costa mais sujeitos a sofrerem sobrelavagem em eventos de tempestade;

- Reconhecimento dos cenários mais prováveis que causam sobrelavagem da costa. 


\section{4 Área de Estudo}

\subsection{Caracterização da Área de Estudo}

Ao sul da Ilha de São Vicente encontra-se a Baía de Santos, que engloba todas as praias da cidade de Santos e São Vicente (Figura 4.1). A baía de Santos tem seu limite delimitado a oeste pela Ponta de Itaipu, São Vicente e a leste pela Ponta da Macumba, Guarujá (Gregorio 2009). Sua abertura para o oceano tem, aproximadamente $7 \mathrm{~km}$ de extensão e seu comprimento da região da abertura até a linha de costa é de aproximadamente $11 \mathrm{~km}$ (Gregorio 2009). Esta recebe águas estuarinas provenientes de dois canais: Canal de São Vicente, a noroeste, e Canal do Porto, a nordeste.
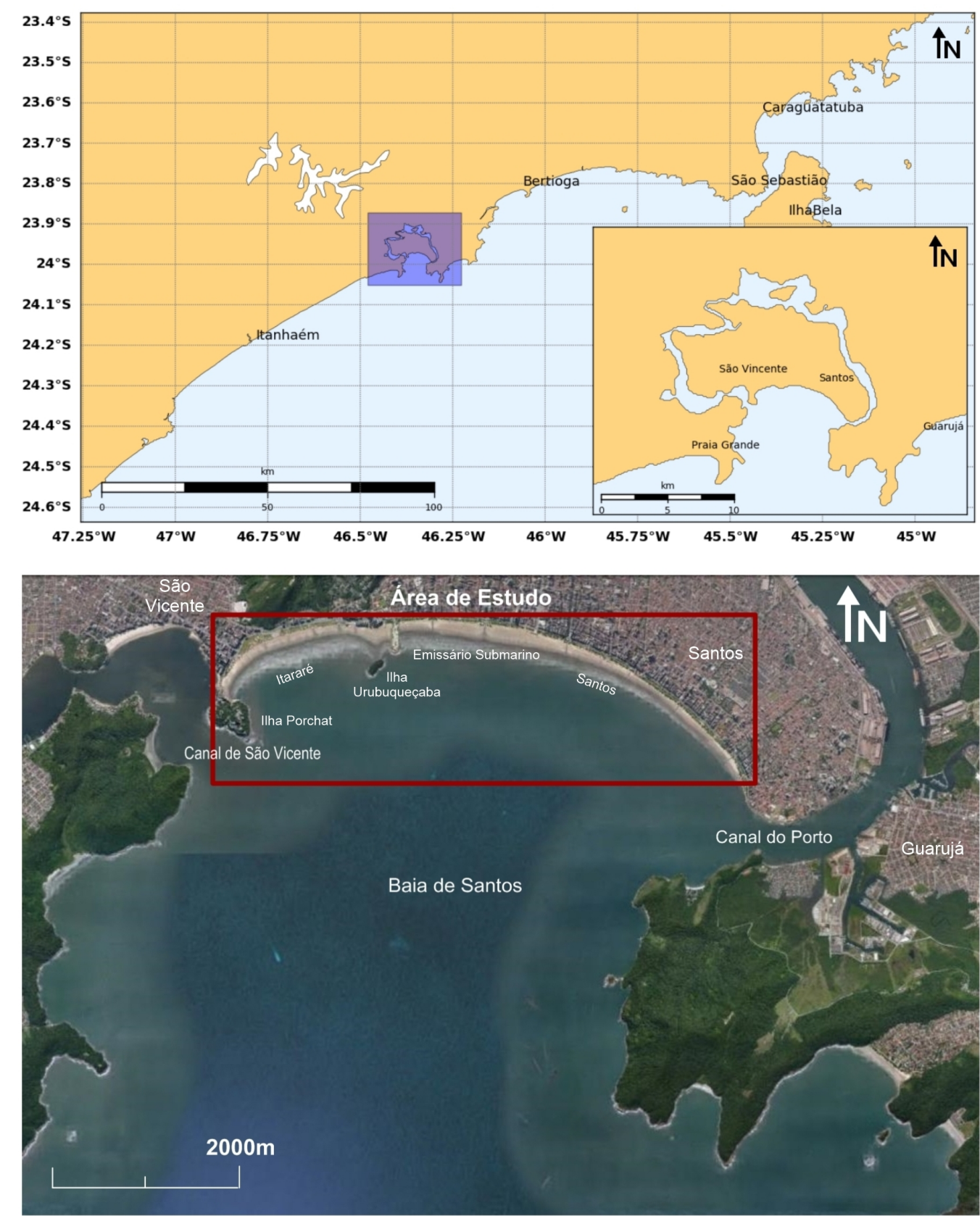

Figura 4.1: Localização da área de estudo (Imagem: Google Earth). 
A baía apresenta orientação voltada para sul e fica exposta à ação de ondas originadas pelos sistemas frontais do quadrante sul. A ilha de Urubuqueçaba, localizada próximo à divisa de Santos e São Vicente, serve de barreira natural ocasionando a difração de ondas resultando na formação de um tombolo devido à área de sombra. Próximo à zona de sombra causada pela ilha, está instalado o emissário de Santos. Como ele está instalado em um região naturalmente mais protegida da ação das ondas, esta obra não afeta muito a dinâmica da praia.

A faixa praial de Santos apresenta direção aproximada de E-W, mais estreito na porção leste próximo ao Canal do Porto e mais largo no centro. Sua extensão foi subdividida regionalmente em 8 praias com nomes diferentes: Itararé (no município de São Vicente); José Menino; Pompéia; Gonzaga; Boqueirão; Embaré; Aparecida e Ponta da Praia. No caso da ilha de São Vicente, as praias oceânicas apresentam comportamento morfodinâmico bastante similar entre si, tendendo a ser dissipativas a intermediárias (Farinnaccio, Goya, e Tessler 2009).

Tanto na baía de Santos quanto na baía de São Vicente, não existe aporte de sedimento, o que indica que a fonte de alimentação destas praias está localizada no interior dessas baías (Rocha 2003). Os estudos de Rocha (2003) indicaram que o transporte de sedimento ocorre paralelamente à Ilha de São Vicente de leste para oeste, a partir do Canal do Porto e também de oeste para leste proveniente do Canal de São Vicente. A confluência dos dois transportes gera uma grande zona de deposição na porção centro-oeste da baía.

No município de Santos a divisão das praias corresponde com a localização de 6 canais de drenagem pluvial instalados ao longo do arco praial, em um intervalo de aproximadamente $1 \mathrm{~km}$. Estes canais foram construídos perpendicularmente a linha de costa com o objetivo de ligar o estuário com o mar para circulação da maré e drenagem da área urbana.

Em adição aos canais de drenagem, está presente no interior da baía o emissário submarino de Santos, José Menino. Este está localizado próximo ao canal 1 e foi construído na década de 70. O emissário possui aproximadamente $300 \mathrm{~m}$ de extensão na parte exposta e vem afetando o aporte de sedimento para as praias a oeste, pertencentes ao município de São Vicente e para a Ponta da Praia em Santos. Segundo (Farinnaccio, Goya, e Tessler 2009) após a instalação do emissário submarino a ponta da Praia passou a apresentar um recuo da linha de costa, sugerindose que a causa desde recuo seja devido à ausência de aporte de sedimentos que se acredita estar sendo retidos no emissário.

A orla de Santos é toda coberta por um calçadão causando a impermeabilização do solo a partir do pós-praia (Elliff et al. 2013). Portanto esta área fica sujeita a invasão de água do mar sobre as ruas e calçadas, sendo assim uma região de risco. Além dos impactos gerados pelos canais e pelo emissário, no passado os sedimentos da dragagem do canal do porto eram indevidamente descartados na Baía de Santos, ocasionando impactos ambientais na região.

O município de Santos conta com 419.400 habitantes, atingindo uma densidade demográfica de 1.494,26 hab./ $\mathrm{km}^{2}$. Enquanto o município de São Vicente que possui uma área territorial menor que Santos conta com 332.445 habitantes, portanto a densidade demográfica é maior que a do município de santo, sendo de 2.247,88 hab. $/ \mathrm{km}^{2}$ (IBGE 2010). A região da ilha de 
São Vicente possui também uma população flutuante significativa em alta temporada de verão, por ser uma região muito procurada pelos paulistas para uso recreativo do litoral. Santos é economicamente voltado para o turismo e as atividades portuárias, comércio e pesca; devido a presença do maior porto da América Latina no canal de Santos.

\subsection{Formação Geológica e Características Geomorfológicas}

O litoral paulista está contido na unidade "Província Costeira", a qual é subdividida em Serrania Costeira e Baixada Litorânea, onde que cada um possui características geomorfológicas próprias.

A formação do litoral paulista ocorreu devido ao conjunto de dois fenômenos de distintas escalas temporais. Primeiramente houve o soerguimento da Serra do Mar em conjunto da subsidência da Baía de Santos, relativos às reativações tectônicas ocorridas no final do Cretáceo (Almeida, Hasui, e Neves 1976). Em segundo houve as variações do nível do mar durante o período do Quaternário.

No litoral Paulista foi registrada a existência de dois eventos transgressivos-regressivos: Cananéia e Santos (Suguio e Martin 1978). A ilha de São Vicente foi formada durante o último evento transgressivo, apresentando um modelado de cordões litorâneos e afloramentos do Embasamento cristalino em forma de morros. A região é limitada por duas unidades morfotectônicas, a Baía de Santos e a Serra do Mar (Ab’Saber 1969; Ponçano 1985).

A Baía de Santos, segundo o estudo feito por (Rocha 2003), possui a porção oeste levemente mais rasa que a porção leste, apresentando uma feição em forma de canal, que propicia o transporte de sedimentos baia adentro. Este estudo também observou o predomínio da fração de areia em toda a baia e presença sedimentos siltosos em maior quantidade na porção centro-oeste, sudeste e na desembocadura do Canal do Porto.

\subsection{Meteorologia}

Os dados climáticos são essenciais para a compreensão dos processos erosivos e deposicionais costeiros, por responderem diretamente pelos fenômenos de deslocamentos do nível do mar, de circulação das águas costeiras e pelas ondas geradas pelas condições meteorológicas. Assim, os sistemas frontais do litoral paulista são a base para compreender a origem das modificações de pequena escala de tempo da morfologia costeira.

As perturbações frontais são controladas pela alternância de duas massas de ar, uma de origem tropical marítima e outra polar marítima. Segundo Martins (2006), esse processo é controlado pela interação dos Anticiclones Migratórios do sul ou Anticiclones Polares Móveis, antecedidos pelas frentes frias, e o Anticiclone Tropical Atlântico, ou ainda, o Anticiclone semipermanente do Atlântico, que é responsável pela geração do vento que vem do oceano em direção ao continente durante todo o ano (Martins 2006). 
As frentes frias se dão devido ao contato entre duas massas de ar com características diferentes de temperatura e os ciclones regiões de baixa pressão com circulação horária (no Hemisfério sul) que se deslocam de uma região para outra e dissipam-se (Reboita et al. 2012).

Os Anticiclones Polares Móveis acarretam em frentes frias que são acompanhadas por chuvas torrenciais e nebulosidade. Ocorrem também mudanças na direção do vento, o qual passa a soprar do quadrante sul, e é responsável por sistemas de ondas de sul e sudeste. Em média a propagação de uma frente fria sobre a plataforma continental sudeste leva 2 dias (Stech e Lorenzzetti 1992). No período do inverno as frentes frias aumentam em frequência, intensidade e velocidade de deslocamento (Lemos e Calbete 1996).

Segundo o estudo de Farinnaccio, Goya, e Tessler (2009) à distribuição sazonal das precipitações no litoral paulista, no período de primavera e verão há maior ocorrência de chuvas. Também observado que em ambos, inverno e verão, as variações pluviais foram mais constantes e que o caráter excepcional de alguns anos foi causado pela grande elevação ou redução das chuvas no outono e na primavera.

O nível do mar pode se elevar significativamente causando inundações na costa, quando o litoral é atingido por fortes tempestades durante os períodos de máxima maré astronômica (Campos, Camargo, e Harari 2010). Neste estudo de Campos, Camargo, e Harari (2010) foi observado que as medidas positivas de maré meteorológica estão associadas a pistas de vento com velocidades acima de $8 \mathrm{~m} / \mathrm{s}$ próximo à costa, concluindo-se que os fenômenos extremos dependem da evolução temporal e da persistência da pista de vento.

\subsection{Características Oceanográficas}

As principais forçantes que influenciam na circulação da Baia de Santos são os gradientes baroclínicos de pressão causados pelas descargas fluviais dos principais canais existentes, Canal do Porto e Canal de São Vicente; as marés e os ventos sinóticos, além da geomorfologia de fundo, que também apresenta papel fundamental na circulação da baia (Harari e de Camargo 1998).

O litoral sul paulista é caracterizado pelo regime de micro maré semi-diurna, ou seja, com amplitude menor que $2 \mathrm{~m}$ e picos que ocorrem duas vezes por dia (Gagliardi 2013). Em situação de baixa mar na baia de Santos, observam-se evidências de movimentos anti-horários, associados principalmente à geomorfologia de fundo e efeito dinâmico do fluxo do Canal do Porto. Enquanto, em maré alta, há correntes em direção ao mar aberto na porção mediana da baia (Fúlfaro e Ponçano 1976).

Na ocorrência de tempestades em conjunto com o período de máxima maré astronômica (sizígia) o nível do mar pode se elevar extraordinariamente causando inundações na costa (Campos, Camargo, e Harari 2010). A diferença entre a maré observada e a maré astronômica prevista para o local, é definida como maré meteorológica e quantifica a influência desse tipo de fenômeno sobre a orla continental. No estudo de Campos, Camargo, e Harari (2010) foi obtida 
também a porcentagem de eventos de sobre-elevação do nível do mar para cada estação do ano na região de Santos entre os anos de 1951 e 1990. Considerando todo o período analisado, chegou-se à média anual para Santos, de 12 eventos de maré meteorológica acima de +0.38 metros, e 7 eventos de maré meteorológica abaixo de -0.38 metros. Segundo o estudo a ocorrência média foi de $14.5 \%$ na primavera, $13.4 \%$ no verão, $40.2 \%$ no outono e $30.8 \%$ no inverno.

No sudeste brasileiro, podemos dividir o clima de ondas de acordo com as estações do ano. Segundo estudo de Pianca, Mazzini, e Siegle (2010), que caracterizou o clima de ondas na costa do Brasil, o sudeste junto com a região sul apresenta as maiores alturas de ondas. Este estudo mostra também que durante o verão, o outono e o inverno as ondas são preferencialmente de sul. As ondas atingem as maiores alturas quando vindas de sudeste e no inverno quando vêm de sul. Na primavera a direção predominante é leste, e assim como no verão apresenta as menores alturas de onda (1 - $2 \mathrm{~m})$. As maiores alturas ocorrem no período de outono e inverno (2 - $3 \mathrm{~m})$, quando os períodos de onda também são maiores (10 - 12 s). A região das praias da ilha de São Vicente é suscetível a ondas de sul e sudeste que apresentam maiores altura de onda e são mais frequentes em épocas de outono e inverno.

O estudo de Rocha (2003), indica que o transporte de sedimento ocorre paralelo à Ilha de São Vicente, na direção leste-Oeste, a partir do Canal do Porto em direção à Ilha Porchat e na direção oeste-Leste proveniente do Canal de São Vicente, ocorrendo a confluência dos dois transportes ao sul da Ilha Porchat, condicionando uma zona de deposição na região CentroOeste da Baía de Santos. Nessa área há maior deposição de sedimentos finos e matéria orgânica que é controlado pela hidrodinâmica da área e influência do Emissário Submarino José Menino. Além disso, foi observada uma área de deposição de sedimentos ao sul da Ilha de Santos Amaro e transporte Norte-Sul na porção leste da baía.

O trabalho de Fukumoto (2003) indicou outros dois setores com maior deposição de sedimentos finos e matéria orgânica. A desembocadura do Canal do Porto, onde a sedimentação está possivelmente relacionada à quebra de energia do fluxo no encontro das águas do canal com a baia e a Ponta da Munduba, onde a sedimentação está relacionada com fatores hidrodinâmicos e possível influência do descarte de dragagens de décadas anteriores (Fukumoto 2003). 


\section{Morfodinâmica e Modelagem de Ondas}

\subsection{Introdução}

Os principais processos que controlam as praias são as correntes, as marés e as ondas. No caso de ondas, a energia que atinge a zona costeira é definida pelo clima de onda da região. O balanço energético entre as ondas de bom tempo e de tempestade que chegam na costa é o processo responsável pelo controle da deposição ou remoção de sedimentos na praia, causando mudanças no perfil topográfico (Komar 1998).

As ondas que se propagam no mar aberto passam por processos de transformação quando alcançam a costa e dissipam energia no processo de quebra, gerando correntes costeiras que definem o transporte de sedimentos e controlam a morfodinâmica da praia. Os eventos de alta energia associados a tempestades e ondas de tempestade são importantes fatores na evolução costeira (Stone e Orford 2004) e apresentam resultados variáveis em função dos diferentes processos de transformação das ondas à medida que se propagam em direção a costa (Regnauld et al. 2004).

As praias urbanizadas são ambientes complexos devido à interação de ocupação antropogênica e processos costeiros. De acordo com Souza (2009), a interferência antropogênica com o meio ambiente pode modificar os fatores naturais, que por sua vez estão relacionados a fatores oceanográficos e hidrológicos, como correntes, ondas e marés. Portanto, a intervenção humana pode ser a causa direta dos processos sedimentares que influenciam o equilíbrio de sedimentos de uma praia.

Assim, o objetivo desse capítulo é entender melhor o comportamento morfodinâmica das praias urbanizadas de Santos e Itararé. Serão apresentados a seguir os métodos utilizados na coleta de dados topográficos em campo, no processamento e análise desses dados e na modelagem numérica de ondas na baía de Santos. E na sequencia são apresentados os resultados obtidos no estudo morfodinâmico e uma discussão dos resultados morfológicos comparados aos resultados do modelo numérico de programação de ondas.

\subsection{Métodos}

Para o presente estudo, foi combinada a coleta e análise de dados topográficos em campo nos anos de 2015 e 2016, modelagem numérica da propagação de ondas na região utilizando o programa Delft3D para o mesmo período de levantamento topográfico.

\subsubsection{Levantamento de Campo}

A área do levantamento topográfico compreende as sete praias do município de Santos e a praia de Itararé no município de São Vicente. O levantamento abrange desde o pós-praia (começo da praia no calçadão) até o início da antepraia. Foram realizadas seis coletas durante o 
ano de 2015 no período de abril; maio; junho; julho e agosto, a cada 20 dias, aproximadamente, nas praias de Santos. Em 2016 foram realizados 5 levantamentos, nos meses de maio; julho; agosto; setembro e novembro. Foram também realizadas 4 levantamentos na praia de Itararé, São Vicente, em julho, agosto, setembro, novembro.

Para a coleta dos dados de perfil praial, foram realizados levantamentos topográficos a partir da utilização do Sistema de Posicionamento Global Diferencial (DGPS). Os dados DGPS podem ser estáticos ou cinemáticos. O modo cinemático é utilizado para obter dados de forma contínua. O método consiste na utilização de dois ou mais GPS, sendo um dos receptores fixo, colocado em um ponto com coordenadas conhecidas, enquanto que a unidade móvel coleta dados de pontos desconhecidos. Ambos os receptores recebem sinais dos mesmos satélites, partindo do pressuposto de que o erro dos receptores é semelhante em uma área limitada é possível calcular a distância entre os receptores e os satélites. Assim, as diferenças são transmitidas e utilizadas nas correções do receptor móvel. Para a realização deste trabalho foi utilizado os aparelhos do modelo Trimble 5700 como receptor fixo e móvel, além do Trimble R4 como receptor móvel.

Durante os trabalhos de campo, o receptor fixo foi instalado em um ponto previamente georreferenciado no Emissário Submarino José Menino. Este receptor é programado para coletar pontos a cada segundo no modo de levantamento estático. O receptor obtém as informações necessárias para realizar a correção no processamento dos dados levantados pelo receptor móvel, o qual foi programado para coletar dados a cada segundo no modo de levantamento PP cinemático.

Os dados obtidos são processados no software Trimble Business Center ${ }^{\circledR}$, que fornece os dados em planilhas contendo posição (latitude e longitude) e altimetria de cada ponto de coleta. A partir do programa MAPGEO2010 do IBGE são obtidas as elevações do modelo geóide adotado no Brasil (SIRGAS2000). Para corrigir os dados do DGPS para o modelo geoidal e utilizada a Equação 1, na qual, a altitude elipsoidal (h) é convertida em altitude ortométrica (H) e $\mathrm{N}$ é a altura (ondulação) geoidal fornecida pelo programa, de acordo com a convenção que considera o geoide acima do elipsoide se a altura do geoidal for positiva e abaixo em caso contrário (IBGE 2016), como ilustrado na Figura 5.1. 


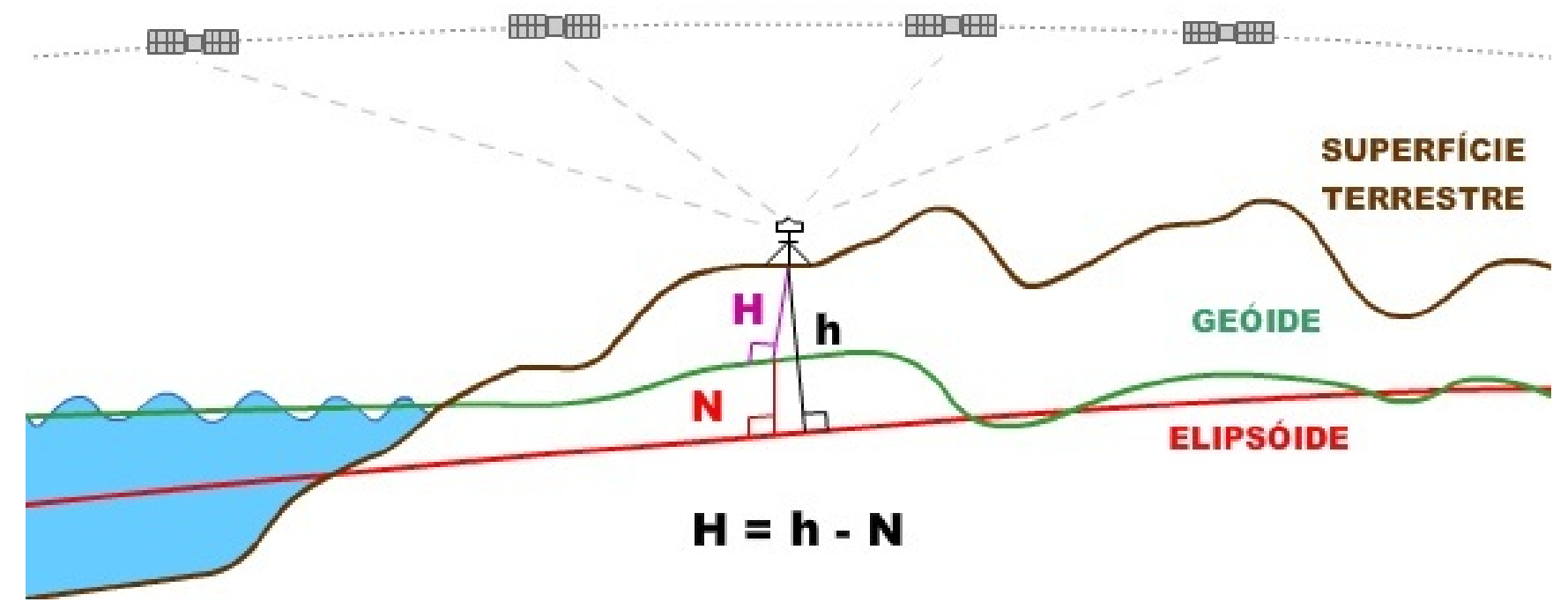

Figura 5.1: Ilustração da correção ortométrica aplicada nos dados retirada do site do IBGE (2016).

$$
H=h-N
$$

Os dados corrigidos são tratados e analisados no software Surfer $11^{\circledR}$ (Golden Software). Neste programa os dados são interpolados através do método de Krigagem (Kriging), para a confecção dos modelos digitais de terreno, com o objetivo de avaliar as modificações morfológicas da praia e a variação do volume de sedimento. Para a avaliação da erosão/deposição na região de interesse foram gerados mapas de diferença altimétrica entre os levantamentos. $\mathrm{O}$ volume foi calculado a partir da integração entre uma superfície $\mathrm{f}(\mathrm{x} ; \mathrm{y})$, parametrizada a partir da malha interpolada e uma superfície plana $\mathrm{Z}$, tendo um mesmo valor como base para todas as malhas. Usando o levantamento com menor alcance horizontal como referência, uma máscara padrão é estabelecida para todas as malhas, a fim de comparar os volumes entre os levantamentos.

Para uma melhor visualização das variações da na praia, Santos foi dividida em 5 setores e Itararé em 3, tendo como base as características morfodinâmicas dos trechos das praias (Figura 6.1). 


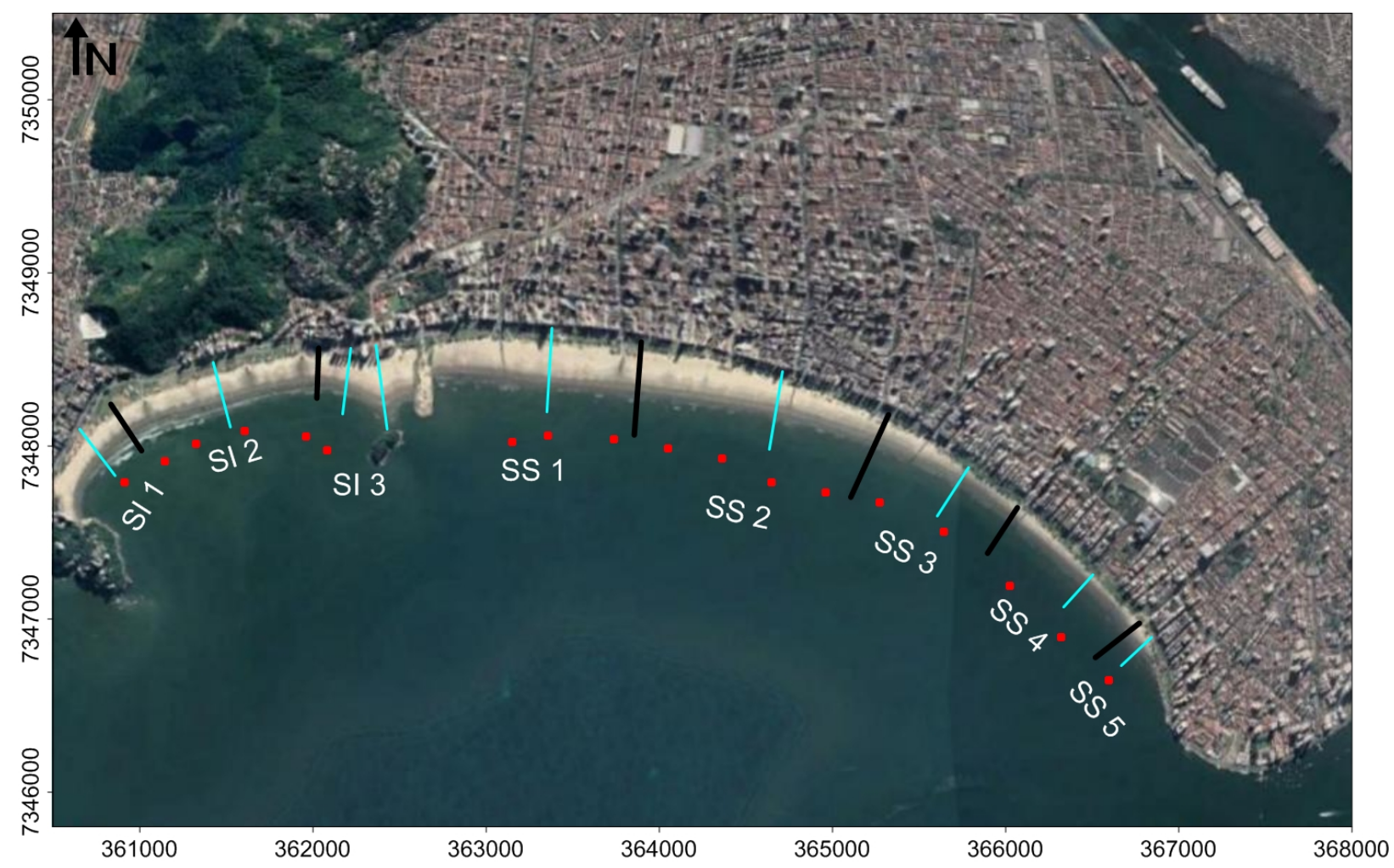

Figura 5.2: Imagem indicando os 5 setores nos quais a praia de Santos foi dividida e os 3 setores da praia da Itararé (As linhas pretas separam os setores). As linhas azuis indicam os perfis extraídos de cada setor e os pontos vermelhos onde foram extraídos os resultados da modelagem numérica.

\subsubsection{Regime de Ondas}

O clima de ondas, foi obtido a partir do banco de dados disponível através do modelo global de geração de ondas do WaveWatch III (WW3), desenvolvido pelo National Center for Enviromental Prediction (NCEP) da National Oceanic and Atmospheric Administration (NOAA). O modelo WW3 utiliza a equação do balanço da densidade de ação espectral para o espectro direcional da onda, incluindo o crescimento, a refração e o decaimento decaimento e, os dados são disponibilizados em uma série temporal de cada mês do ano com intervalo de $3 \mathrm{~h}$ entre os dados. Embora apresentando limitações quando comparadas com os dados medidos in situ, os quadros finais dos modelos globais de geração de ondas foram validados e demonstraram reproduzir bem o clima geral das ondas (Wang e Swail 2001; Tolman et al. 2002; Caires et al. 2004).

Os dados de ondas utilizados neste trabalho foram os parâmetros de período de pico (Tp), altura significativa (Hs) e direção de pico (Dp) extraídas do WW3 da grade global. A série temporal dos dados de ondas de 2015 e 2016, período dos levantamentos morfológicas, foi usada nos experimentos numéricos com o Delft-3D. 


\subsubsection{Modelagem Numérica}

A propagação e transformação das ondas para águas rasas e análise da ação das ondas na região da Baía de Santos, foi realizada através da aplicação do modelo numérico Delft3D (desenvolvido pela Deltares). O modelo numérico considera os processos de refração, reflexão, empinamento da onda e dissipação de sua energia. O conjunto Delft3D é composto por vários módulos, agrupados em torno de uma interface comum, capazes de interagir entre si. Neste estudo foi utilizado o módulo WAVE, esse módulo pode ser usado para simular a propagação aleatória de ondas curtas geradas pelo vento em águas costeiras.

O modelo Delft3D-WAVE utiliza o modelo SWAN (Simulation Waves Nearshore). Este modelo propaga ondas considerando profundidade, correntes, geração de ondas por vento, fricção de fundo e quebra de onda induzida pela profundidade (Deltares 2011), baseando-se na equação espectral discreta do balanço de energia da onda.

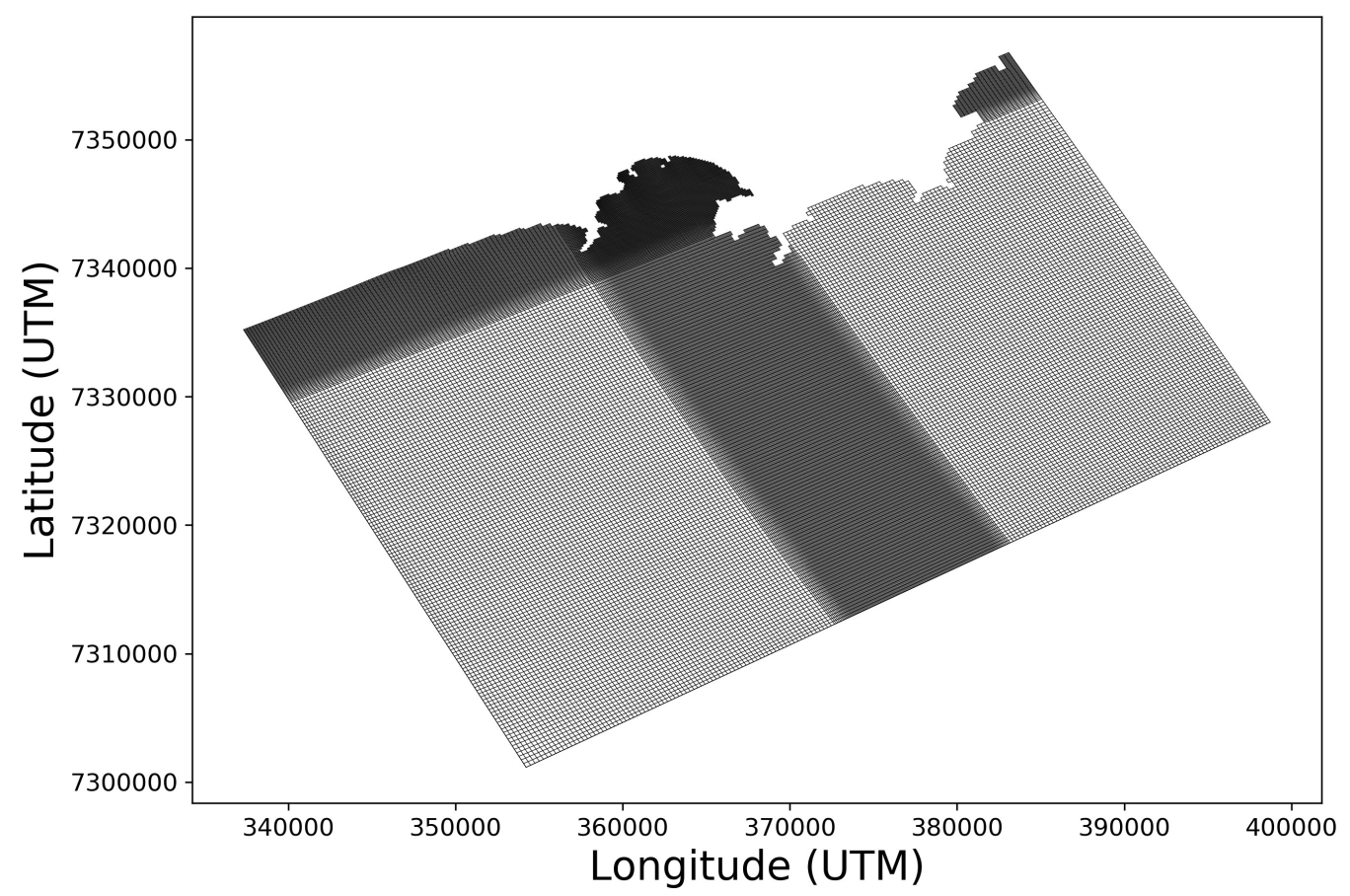

Figura 5.3: Grade usada para a modelagem numérica no Delf3D módulo Wave. Essa grade também foi usada para a interpolação da batimetria usada na modelagem.

Para forçar o Delft3D-WAVE foram usados os parâmetros de altura significativa (Hs), período de pico (Tp) e direção ( $\mathrm{Dp}$ ) do modelo global WaveWatch III correspondentes ao mesmo período de campo para compreender a relação entre a incidência de ondas e a variabilidade topográfica da praia estudada.

A partir dos dados topográficos coletados para as praias de Santos e Itararé, dados batimétricos e de orientação da linha de costa (disponíveis no banco de dados do Laboratório de Dinâmica Costeira (LDC) do Instituto Oceanográfico da USP), foram geradas a grade do modelo e a batimetria de fundo usados nos experimentos numéricos. O domínio do modelo compreende a área de estudo localizada na região central da grade do modelo e se estende na plataforma 
continental. A grade e a batimetria possuem a mesma resolução de 60 m x 60 m na área interna da baía de Santos, e 255 m x 230 m na região oceânica externa (Figura 5.3).

$\mathrm{Na}$ análise dos resultados do modelo foram extraídos valores de $\mathrm{Hs}$, Tp e Dp dos pontos de grade próximos a costa. Ao todo foram definidos 18 pontos, 6 na praia de Itararé e 12 na praia de Santos, em profundidades variando entre $2.75 \mathrm{~m}$ e $3.25 \mathrm{~m}$, antes da quebra da onda. A Tabela 1 mostra a latitude e a longitude de cada ponto ilustrado na Figura 5.4 e profundidade correspondente.

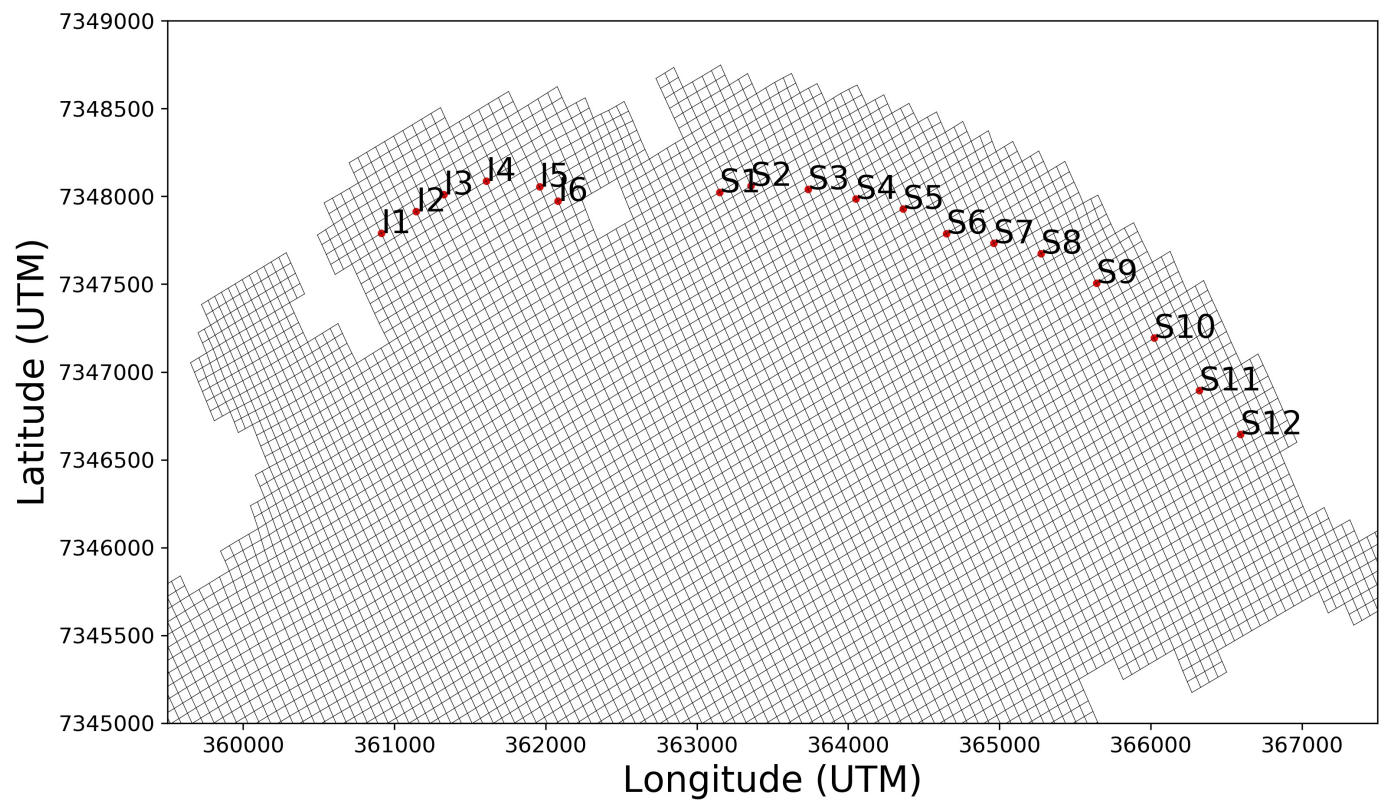

Figura 5.4: Localização dos pontos onde foram extraídos os resultados do da modelagem numérica, indicados na grade modelada. 
Tabela 1: Pontos de extração dos resultados da modelagem numérica, indicando a latitude e a longitude da qual foram extraídos, assim como a profundidade de cada ponto.

\begin{tabular}{|c|c|c|c|}
\hline Ponto & Latitude & Longitude & Profundidade $(\mathrm{m})$ \\
\hline I1 & 7347790 & 360912.5 & 3.21 \\
\hline I2 & 7347913.5 & 361144.3 & 2.92 \\
\hline I3 & 7348009.5 & 361325.2 & 3.23 \\
\hline I4 & 7348086 & 361607.2 & 3.05 \\
\hline I5 & 7348054.5 & 361959.2 & 3.15 \\
\hline I6 & 7347974.5 & 362081.3 & 2.75 \\
\hline S1 & 7348023.5 & 363150.9 & 3.17 \\
\hline S2 & 7348059 & 363357 & 3.13 \\
\hline S3 & 7348039.5 & 363736.2 & 2.85 \\
\hline S4 & 7347985 & 364049.9 & 3.2 \\
\hline S5 & 7347930 & 364361.7 & 2.97 \\
\hline S6 & 7347788 & 364649 & 3.18 \\
\hline S7 & 7347732.5 & 364962.9 & 3.05 \\
\hline S8 & 7347674.5 & 365275.5 & 3.22 \\
\hline S9 & 7347505.5 & 365642 & 2.85 \\
\hline S10 & 7347193 & 366022.6 & 3.15 \\
\hline S11 & 7346894.5 & 366322.4 & 3.15 \\
\hline S12 & 7346644 & 366593.5 & 3.05 \\
\hline
\end{tabular}

\subsubsection{Deriva potencial}

A estimativa potencial da deriva litorânea foi calculada seguindo o método de LonguetHiggins (1970) e Komar (1998), que considera que a energia de onda é diretamente proporcional ao quadrado da sua altura (Davies 1980), e que a intensidade da deriva é proporcional ao ângulo no qual a frente de onda se aproxima à costa (Zenkovich 1967; Komar 1998); dado por:

$$
X=H^{2} \sin \alpha \cos \alpha
$$

Onde $\alpha$ é o ângulo de incidência da onda e H é altura de onda próximo à costa (obtidos pelo resultado da modelagem numérica). A deriva litorânea potencial adimensional (x) foi obtida por unidade de área. Através desse calculo foi possível indentificar regiões de gradiente de transporte positivo, indicando erosão, e negativo, indicando deposição. Este é um método que tem sido aplicado em diversos trabalhos e fornece uma estimativa do potencial de transporte pela 
deriva litorânea (Bittencourt et al. 2002; Bittencourt et al. 2005; Siegle e Asp 2007; Cassiano e Siegle 2010; Sousa 2013), sendo assim considerado apropriado para o objetivo deste trabalho.

\subsubsection{Força de onda}

A partir do resultado de Hs e Tp do modelo foi possível observar calcular a força de onda em cada ponto. A força de onda é um parâmetro que leva em consideração o efeito sinérgico do período de onda e a da altura de onda e pode ser relacionado ao volume praial e a variação de estágios (Short 1978). A variação temporal da força de onda pode alterar o estágio em que a praia se encontra. Pela teoria linear da onda apresentada em Holthuijsen (2007), o fluxo de energia da onda pode ser obtido pelo produto entre a sua energia por unidade de área e a velocidade de grupo da onda. É possível estimar o valor da força de onda pela Equação 3, onde $\rho$ é a densidade da água $\left(1027 \mathrm{~kg} / \mathrm{m}^{3}\right)$, g é a aceleração da gravidade $\left(9.8 \mathrm{~m} / \mathrm{s}^{2}\right), \mathrm{H}$ é a altura de onda local em metros e T o período da onda em segundos:

$$
P=\left(\rho g^{2} H^{2} T\right) / 32 \pi
$$

\subsection{Resultados}

Os resultados são apresentados em dois tópicos. Primeiramente, serão expostos os resultados referentes à Deriva Potencial e a Força de onda, calculados a partir dos resultados de onda do modelo ondas aplicado para a baía de Santos. Em seguida serão apresentados os resultados da morfodinâmica praial, destacando a variação de volume e os perfis praiais.

\subsubsection{Deriva potencial}

A deriva potencial anual, sazonal e correspondente ao período de uma semana antes de cada levantamento topográfico foi calculada para os pontos de extração dos resultados do modelo de ondas, tanto para Santos quanto para Itararé.

A deriva potencial anual em Santos está representada na Figura 5.5, indicando a deriva potencial resultante ao longo de toda a área de estudo, evidenciando um transporte direcionado para noroeste em Santos.

Os pontos $\mathrm{S} 1$ e S2, localizados próximo ao emissário submarino de Santos, apresentaram os maiores valores de transporte, 155 e 181 respectivamente. O ponto S3, o terceiro mais próximo ao emissário também indicou um valor alto de transporte em relação ao restante da praia, 91 . A deriva potencial variou de 25 a 73 no restante dos pontos, com exceção do ponto S12, que apresentou potencial de transporte baixo, de apenas 5 . 


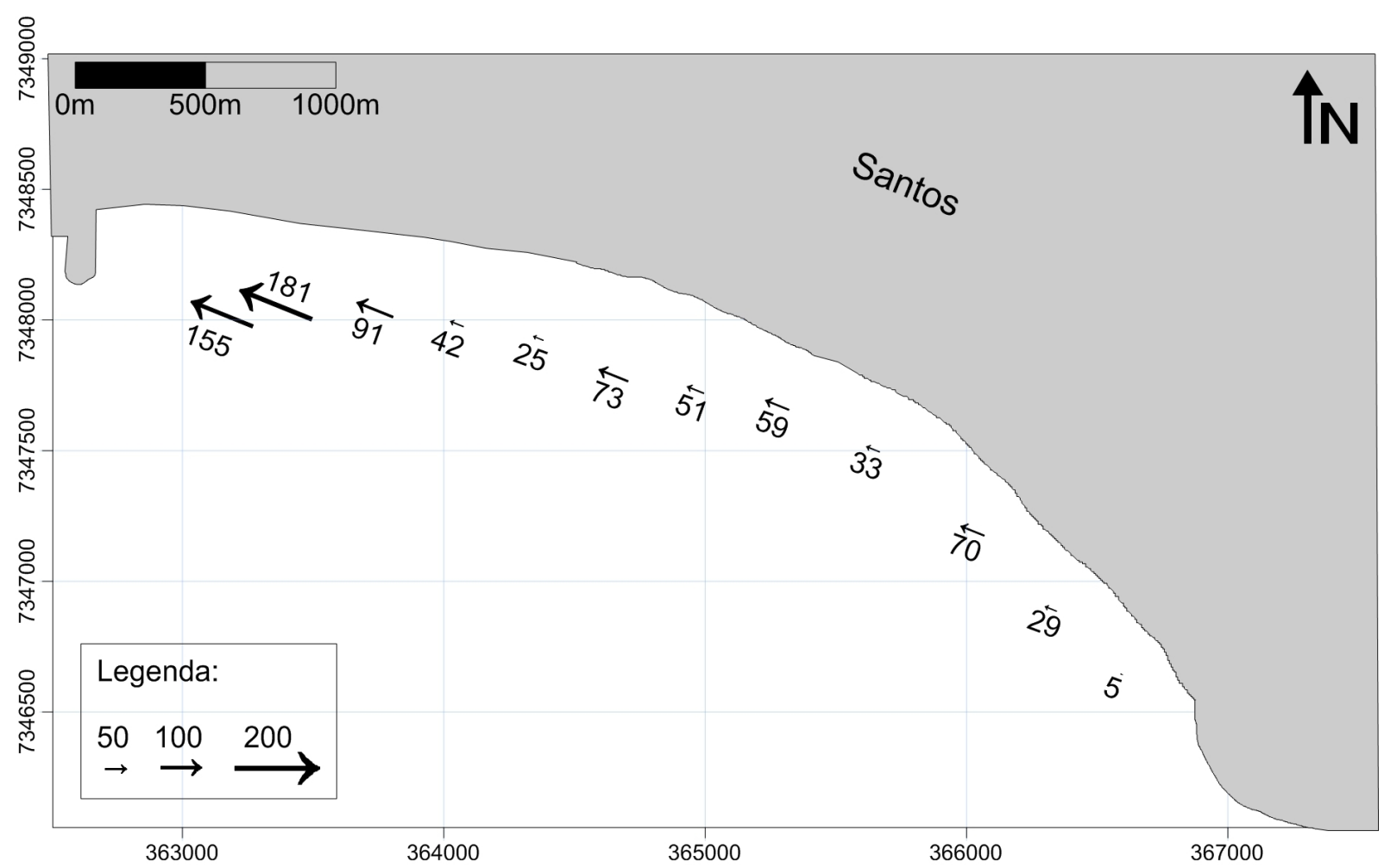

Figura 5.5: Deriva potencial anual da praia de Santos para os 12 pontos.

Pontos de divergência residual, relacionados apenas magnitude e não a direção, foram encontrados ao longo praia. Entre os pontos S2-S3, S3-S4 e S4-S5 na região oeste da praia de Santos, entre os pontos, S6-S7 e S8-S9, na região mais central e S10-S11 e S11-S12, na região mais a leste. Os maiores valores de divergência foram encontrados na região oeste, com diferença de -89 entre os pontos S2-S3 e -49 entre S3-S4. Ao leste na Ponta da Praia os valores de divergência também foram altos, -41 entre S10-S11 e -24 entre S11-S12. Em contrapartida, os trechos entre S1-S2, S5-S6, S8-S7, e S9-S10 apresentaram convergência residual, com valores de $25,48,8$ e 37 , respectivamente.

Na Figura 5.6 observa-se à deriva potencial sazonal, assim como na deriva anual os transportes apresentados nas estações são todos para noroeste, sentido do emissário. As regiões com maior transporte são as mesmas vista no ano como um todo, este padrão se mantém em todas as quatro estações do ano, indicando que as zonas de convergência e divergência residual são as mesmas que as observadas ao longo do ano apenas com intensidades menores. Portanto a praia de Santos mostra um comportamento independente de estações do ano, uma vez que variação entre as estações é muito pequena e varia apensa em intensidade. O potencial de transporte é mais intenso no outono e verão respectivamente, e menos intenso no inverno do que na primara. As ondas mais fortes na primavera e no inverno são mais de sul, consequentemente chegam mais paralela a costa gerando menos deriva, enquanto as ondas de outono e verão chegam com maior ângulo na costa gerando mais deriva. 


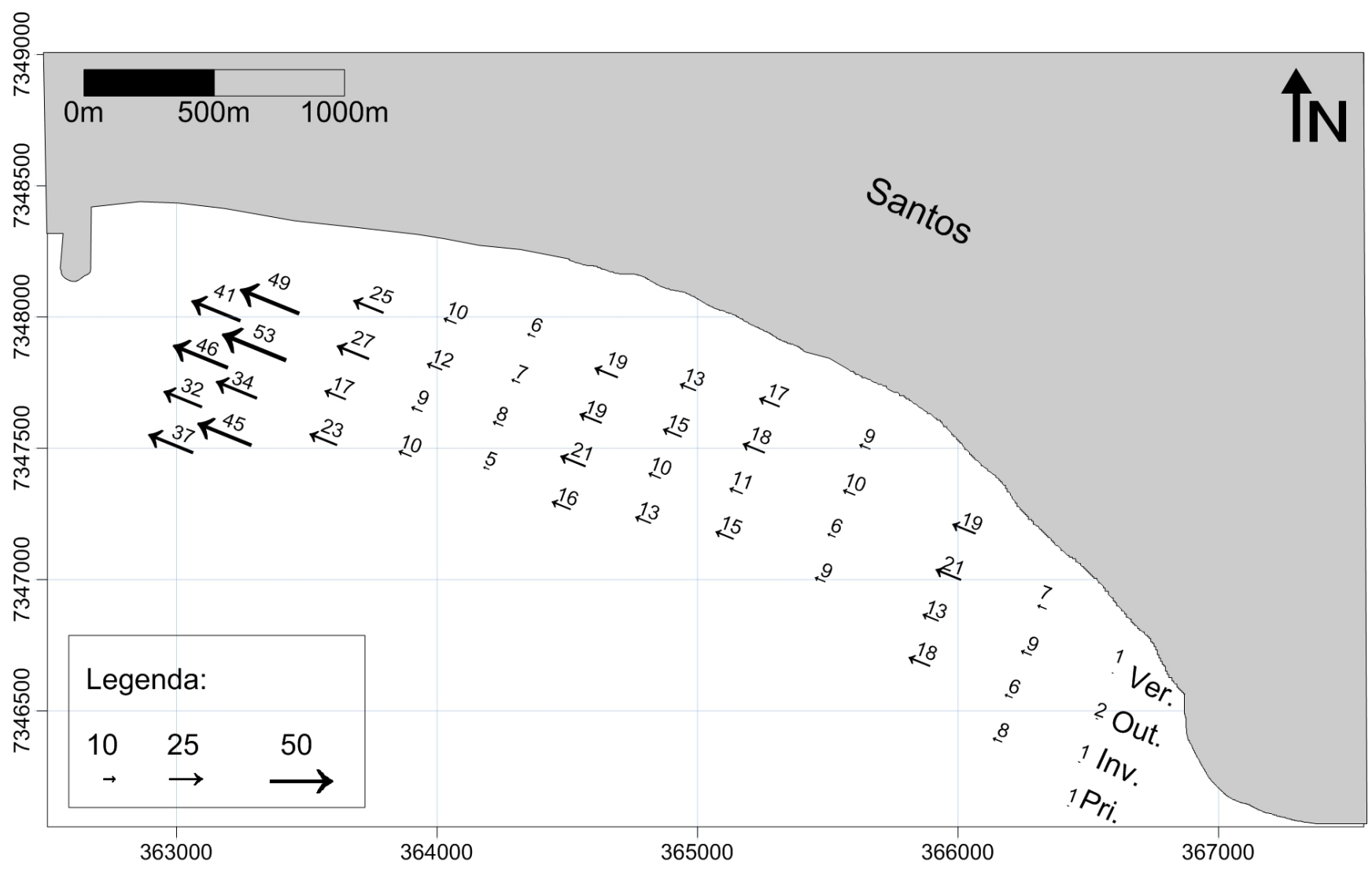

Figura 5.6: Idem a Figura 5.5, mas indicando a deriva potencial sazonal em Santos. A linha de setas mais próxima a costa representa o verão, seguida do outono, do inverno e da primavera consecutivamente.

Para uma melhor análise dos processos que influenciaram a morfologia da praia antes de cada levantamento, foi calculado também à deriva potencial para a semana anterior aos levantamentos topográficos, que estão representados nas Figuras 5.7 e 5.8.

Em 2015 foram realizados 6 levantamentos de campo, e foi observado o mesmo padrão de magnitude e direção observado na deriva anual e sazonal, o transporte em todos os pontos de todos os levantamentos se manteve para noroeste. Para alguns levantamentos morfológicos nota-se que a semana anterior apresentou magnitudes maiores, foi o caso dos levantamentos de 26/06, 07/08 e 22/04, em ordem de maior intensidade. Estes três levantamentos mostram no ponto S2 o maior transporte do levantamento, sendo 4.5, 3.9 e 3.3 respectivamente. Os outros três levantamentos indicam um transporte menor, com valores abaixo de 2 . No ponto $S 1$, foram estimados valores de 1.9, 1.21 para os levantamentos de 08/06, 22/05 e 22/07 respectivamente. Não foi possível observar nenhuma relação entre as variações de magnitude entre levantamentos e as estações do ano, uma vez que os três primeiros levantamentos foram realizados no outono e os três últimos no inverno. 


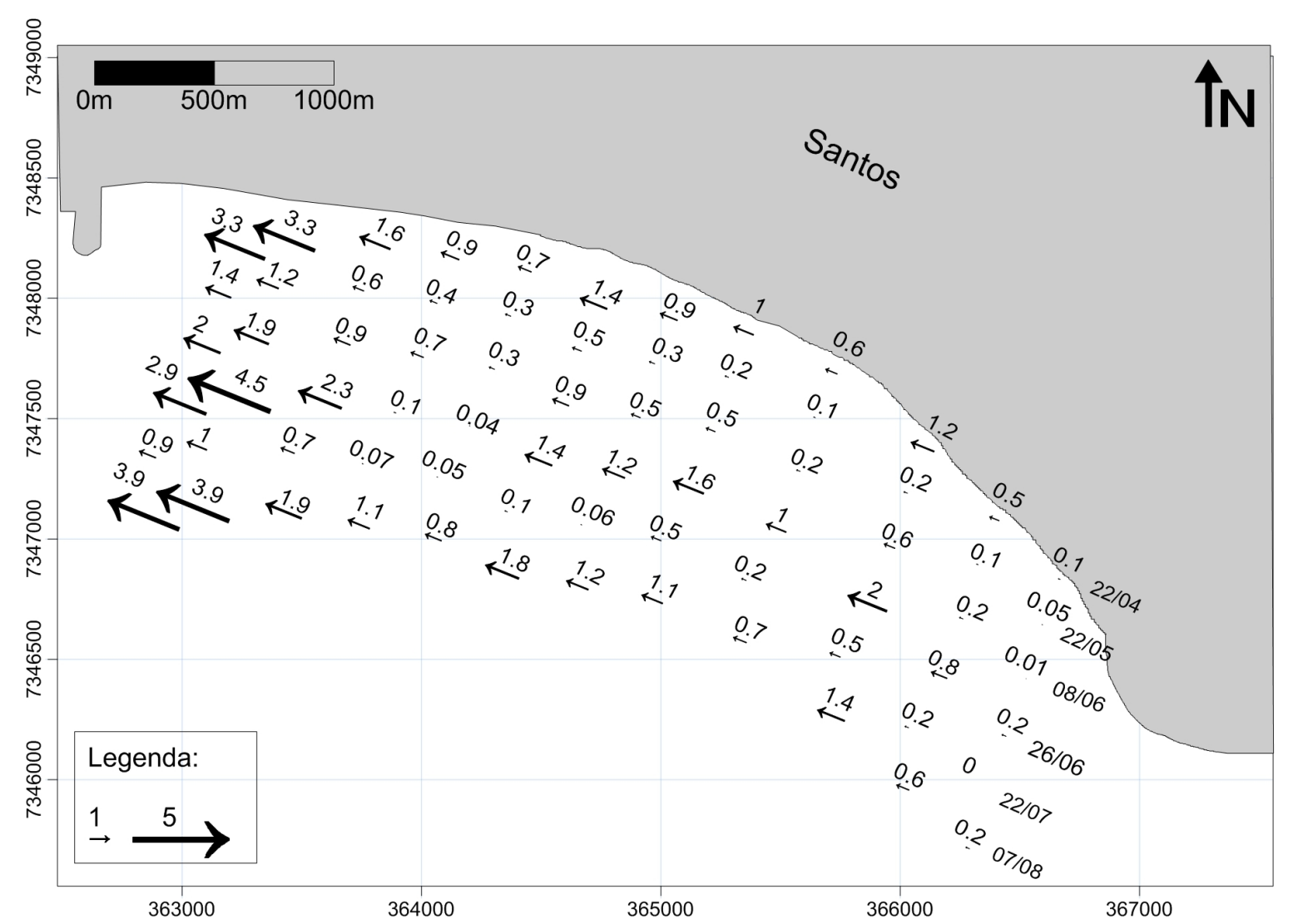

Figura 5.7: Deriva potencial referente à semana anterior de cada levantamento realizado em Santos para os 12 pontos no ano de 2015 .

Em 2016 foram realizados 5 levantamentos topográficos, e em seus intervalos foram observados os mesmos padrões de magnitude e direção da deriva anual e sazonal, com transporte sempre para noroeste. As magnitudes do potencial de transporte foram maiores em 2016 do que em 2015. A semana que antecedeu o levantamento de 30/09, apresentou o maior valor de transporte potencial, foi obtido 8.5 e 6.7 nos pontos S2 e S1, respectivamente, seguido do levantamento de 26/08 que apresentou 6.3 e 5.5 , nos pontos S2 e S1. O período anterior ao levantamento de campo de 06/07 foi o que apresentou menor transporte de todo o período estudado, com valor de 0.9 no ponto S2. A semana que antecedeu o primeiro e o último levantamento apresentou um valor intermediário do potencial de transporte, com 3.6 e 2.7 no ponto S1, respectivamente. 


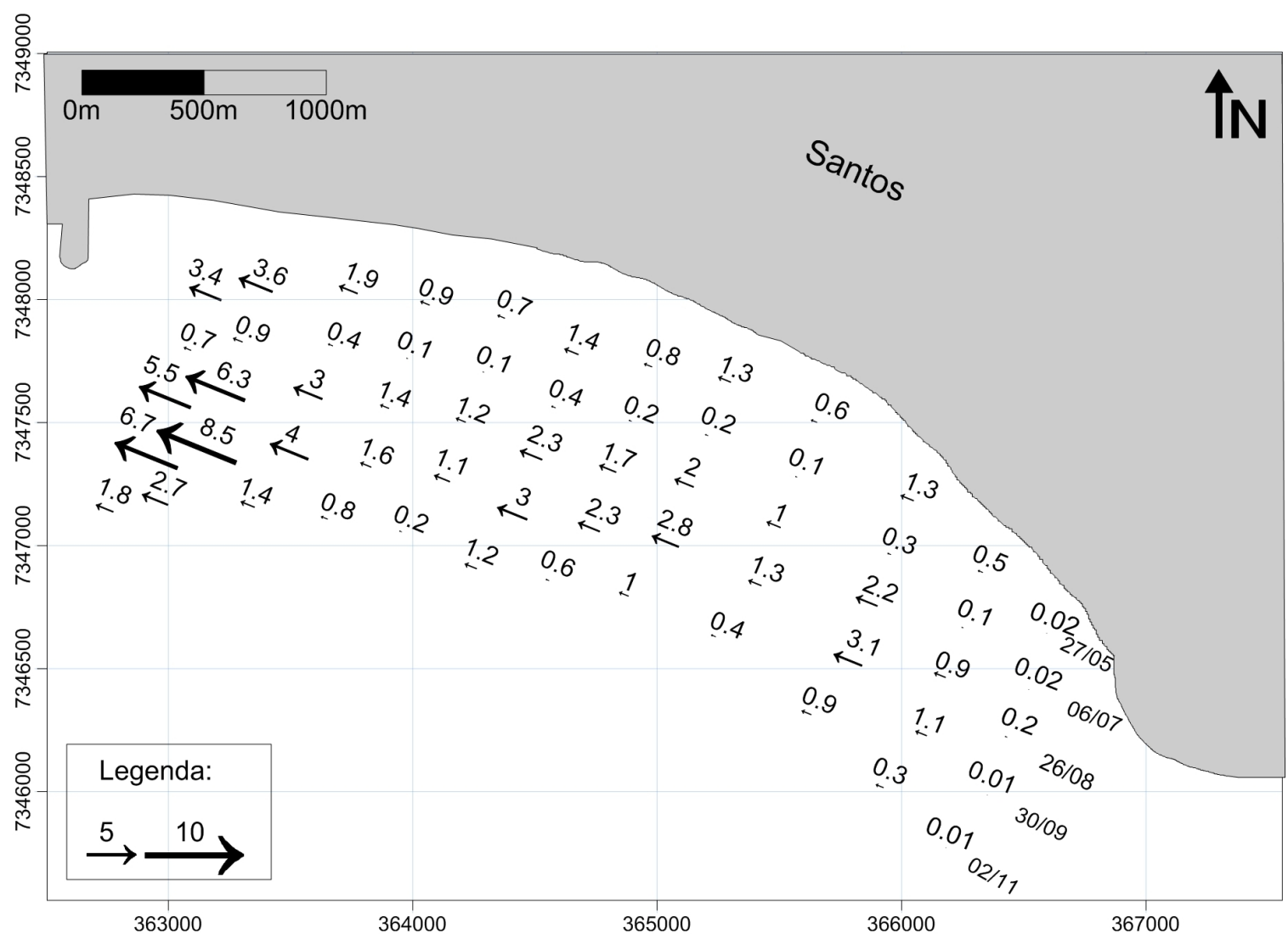

Figura 5.8: Idem a Figura 5.7, mas para os levantamentos de 2016.

Em Itararé a deriva potencial anual apresenta um comportamento diferenciado de Santos e está representada na Figura 5.9, onde nota-se que a deriva potencial resultante no trecho oeste da praia indica um transporte para Nordeste e no trecho leste indica um transporte para noroeste, com uma convergência na parte central da praia. Essa parte central da praia apresenta valores muito baixos de deriva potencial. Nesta praia, observa-se que a deriva potencial apresenta valores maiores que aqueles estimados para Santos. 


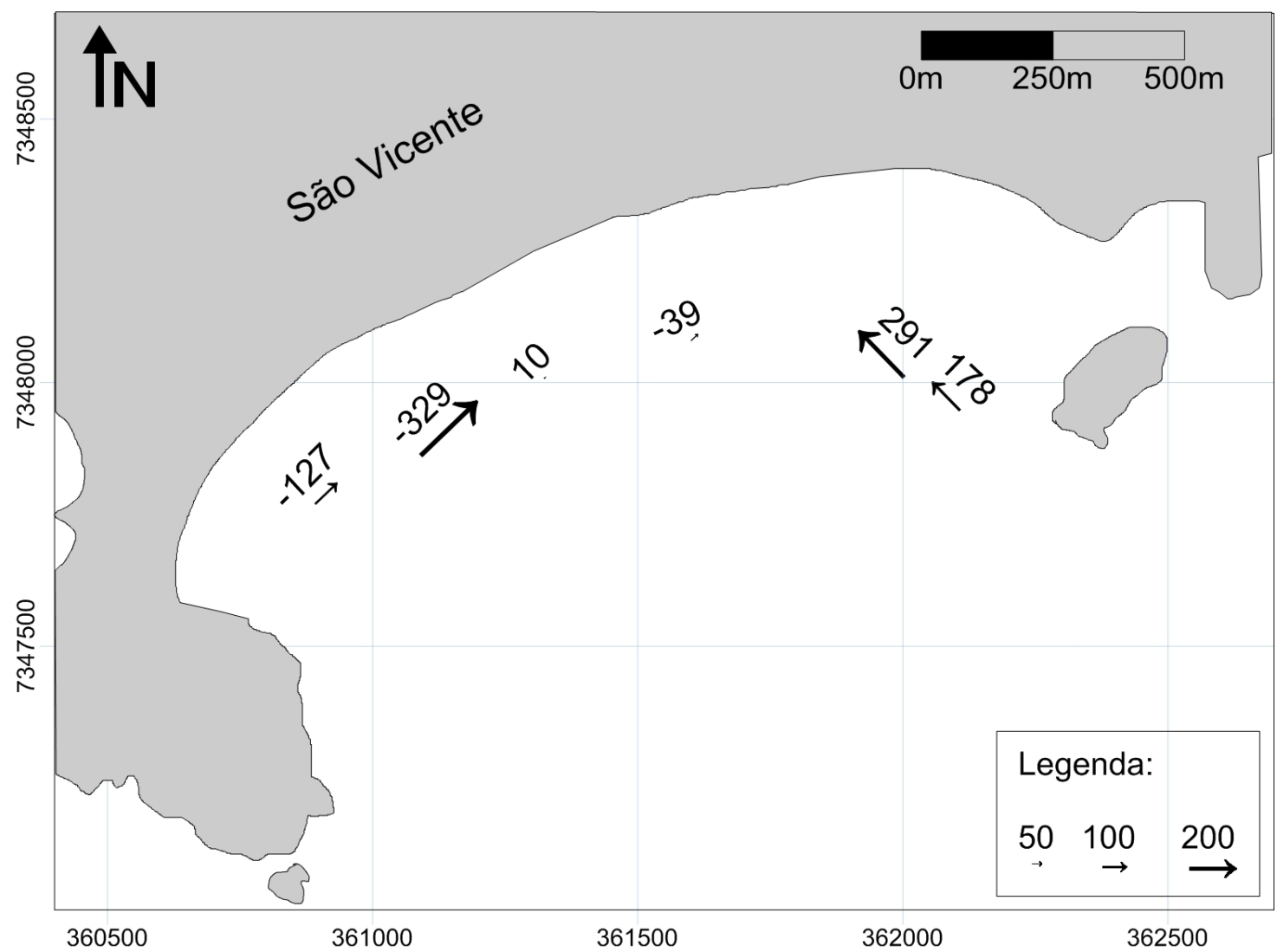

Figura 5.9: Deriva potencial anual da praia de Itararé para os 6 pontos.

Os pontos localizados nos extremos oeste (I1 e I2) e leste (I5 e I6) da praia apresentam os maiores valores de transporte, -127 e -329, 291 e 178 respectivamente. Os pontos centrais, I2 e I3, indicam uma inversão na direção, mas apresentam valores pequenos quando comparados ao restante da praia, 10 e -39 respectivamente.

Itararé apresenta dois pontos de divergência residual, relacionados apenas a magnitude e não a direção, entre os pontos I1-I2 e I5-I6 nos dois extremos da praia, os valores de divergência encontrados foram de -202 e -113 respectivamente. Entre os pontos I2-I3 e I4-I5 observa-se uma convergência direcional, indicando a convergência do transporte nesses pontos e a divergência do transporte entre os pontos I3-I4.

A deriva potencial sazonal está representada na Figura 5.10, indicando a deriva potencial resultante convergindo no centro da praia em todos as estações dos anos, assim como foi observado no ano como um todo. As direções e as magnitudes do transporte em cada estação seguiram o padrão visto na deriva potencial anual, a única mudança é na magnitude apresentada em cada ponto, que é, como esperado, menor que a resultante anual. Da mesma forma que em Santos, Itararé também não apresenta variação de direção das derivas potenciais sazonalmente, observa-se apenas que as magnitudes são diferentes entre as estações. O outono também apresenta as maiores intensidades de transporte, seguido pelo verão e a primavera, o inverno é a estação com menor intensidade no transporte potencial. 


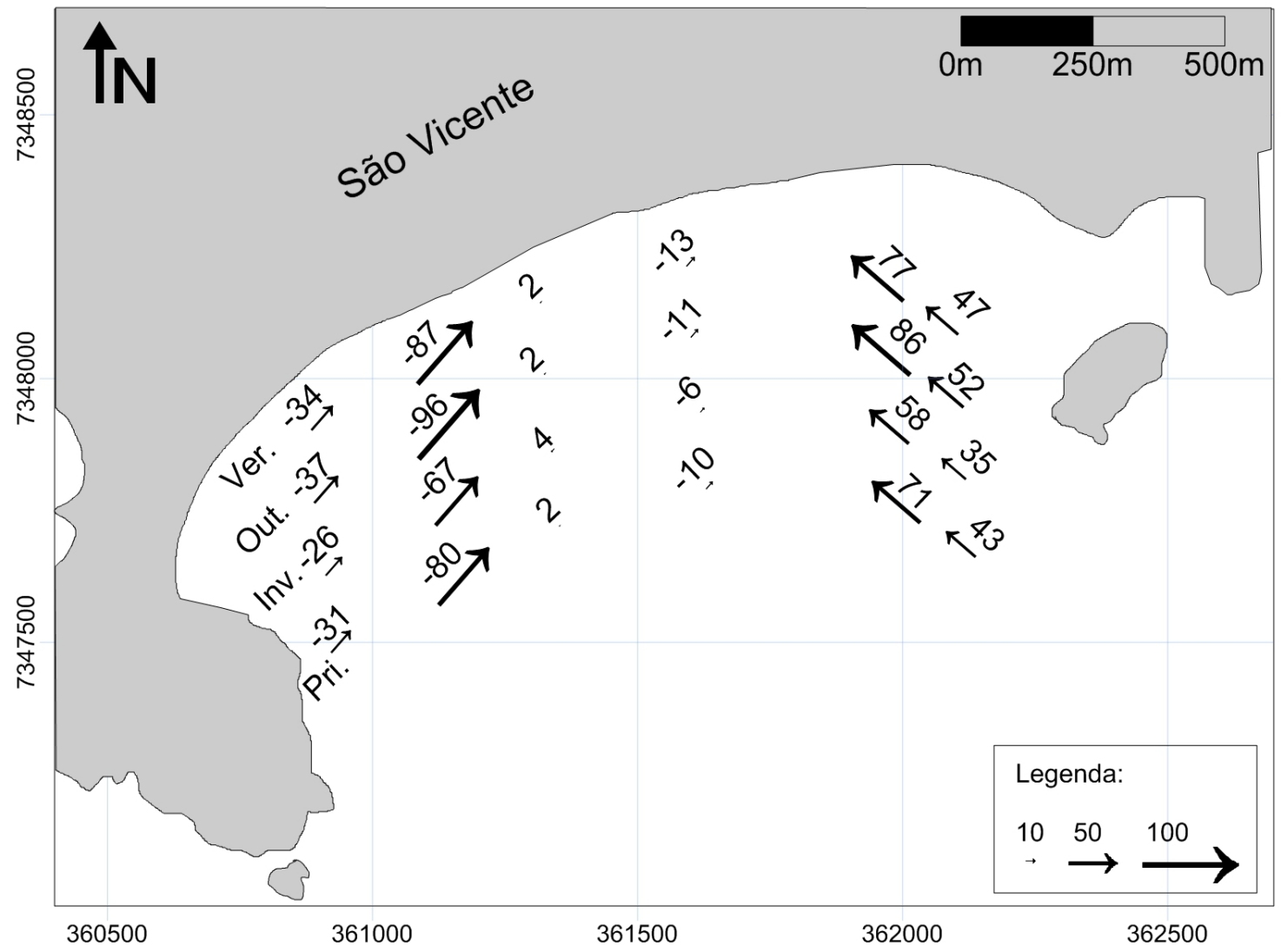

Figura 5.10: Idem a Figura 5.9 , mas indicando a Deriva Potencial Sazonal em Itararé. A linha de setas mais próxima à costa representa o verão, seguida do outono, do inverno e da primavera consecutivamente.

Foi calculada também a deriva potencial para a semana anterior aos levantamentos topográficos (Figura 5.11). Observa-se o mesmo padrão de magnitude e direção visto da deriva anual e sazonal, apenas o ponto I3, na semana anterior ao levantamento de 30/09/16 apresentou mudança na direção. Contudo o valor do transporte nesse ponto foi muito pequeno $(-0.1)$. Interessante observar que nas semanas anteriores aos levantamentos de 26/08/16 e 30/09/16 as magnitudes do transporte foram mais intensas que as apresentadas para a semana que antecede os levantamentos de 06/07/16 e 02/11/16. O período anterior ao levantamento de 06/07/16 foi o que apresentou menor magnitude, -2 no ponto I2, seguido pelo levantamento de 02/11/16 com -4 no ponto I3. Para o ponto I3, nos levantamentos de 26/08/16 e 30/08/16, a magnitude foi de -11 e -12 , respectivamente. 


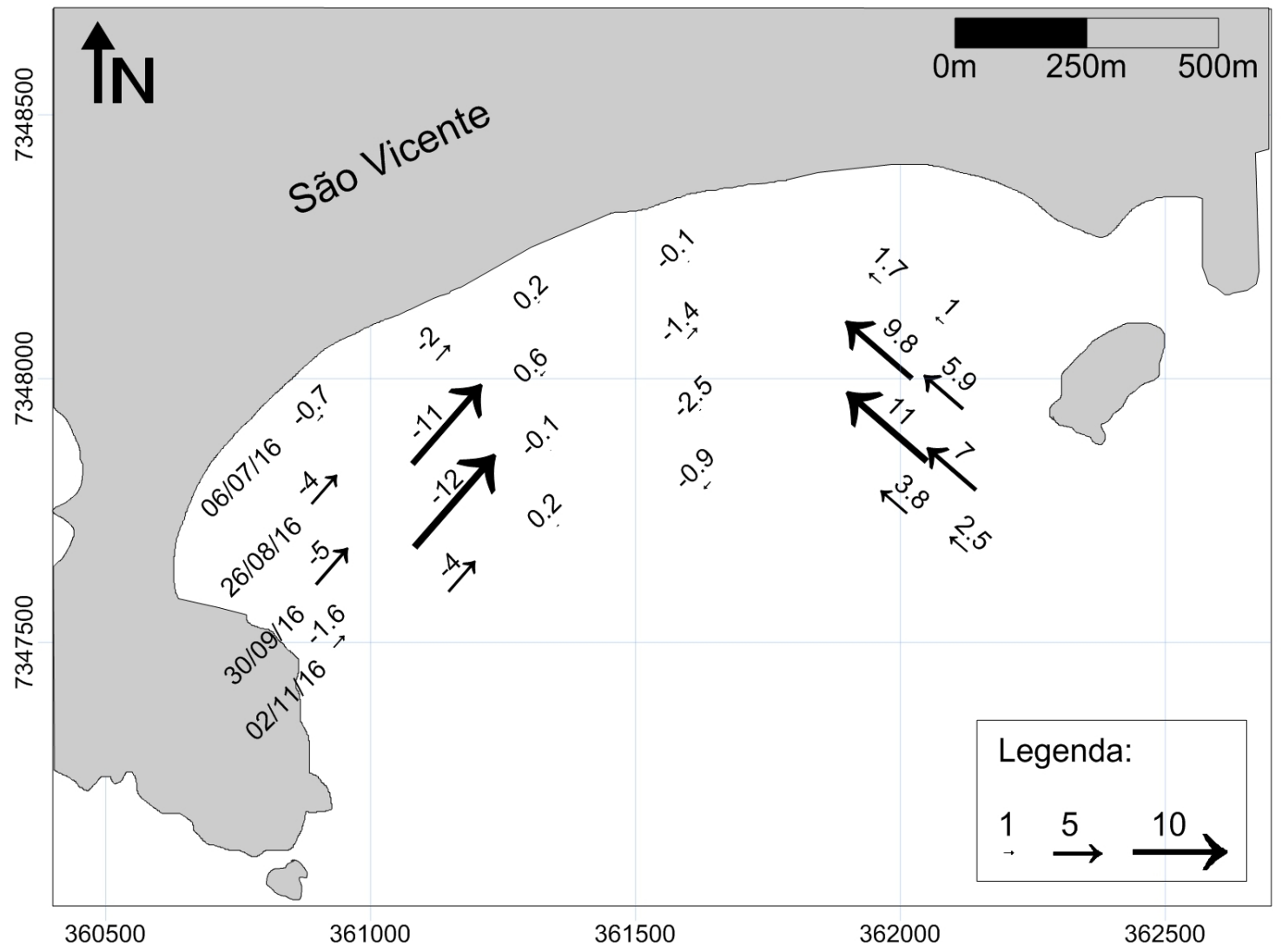

Figura 5.11: Deriva potencial referente à semana anterior da cada levantamento realizado em Itararé para os 6 pontos no ano de 2016.

\subsubsection{Força de onda}

A força de onda foi calculada ao longo de todo o período de 2015 e 2016 . A partir desse resultado foi possível estimar a média anual da força de onda nos pontos usado para extrair dados do modelo em ambas as praias, Santos e Itararé Figura 5.12.

Analisando os resultados relativos à média anual da força de onda, é possível observar que existe variação espacial dessa forçante ao longo das praias da baía de Santos, apresentando maiores valores na praia de Itararé e na porção oeste da praia de Santos. A região central de Itararé apresenta as maiores forças de onda, com valores em torno de $4500 \mathrm{~W} / \mathrm{m}$. Em Santos, os valores atingem cerca de $3200 \mathrm{~W} / \mathrm{m}$ na porção oeste.

Espacialmente, é possível reconhecer os pontos onde há um relativo aumento da força de onda: a região mais central de Itararé (pontos de I2 a I5), onde foram obtidas as intensidades máximas, com valores acima de $3500 \mathrm{~W} / \mathrm{m}$; e a região oeste de Santos (ponto entre S1 a S3), que também apresentou valores relativamente elevados acima de $3000 \mathrm{~W} / \mathrm{m}$. Em contrapartida, a região leste de Santos (pontos entre S4 e S12) são as porções com valores mais amenos, sendo o máximo encontrado nessa região em torno de $2000 \mathrm{~W} / \mathrm{m}$. É interessante ressaltar que o ponto S12, localizado na Ponta da Praia, mostra uma concentração de energia, com picos de força de onda mais intensos que os pontos S8 a S11. Em Itararé os valores de força de ondas mais baixos estão localizados nas extremidades da praia, tanto para oeste quando para leste, onde os valores 
ficam em torno de $2500 \mathrm{~W} / \mathrm{m}$.

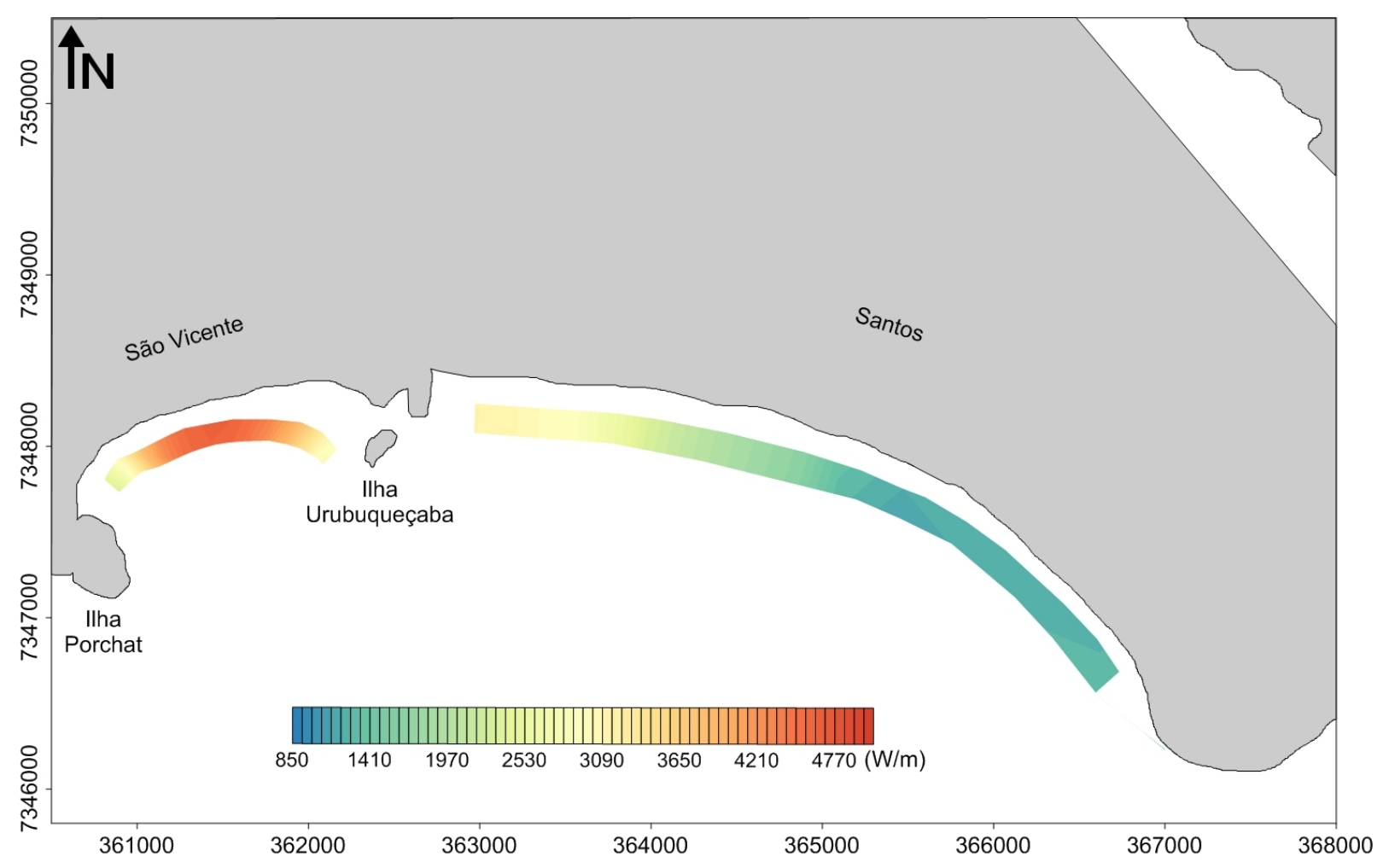

Figura 5.12: Força de onda média anual (W/m) ao longo do arco praial da baía de Santos.

Para uma análise mais completa do efeito das ondas na dinâmica praial de Santos e Itararé, é apresentada a série temporal do cálculo da força de onda nos meses dos levantamentos morfológicos (Figuras 5.13 a 5.16) Comparativamente, o período estudado em 2016 apresentou maior ocorrência de eventos energéticos que o período estudado em 2015. Foram alcançados valores pontuais superiores a $30000 \mathrm{~W} / \mathrm{m}$ em ambas as praias em 2016, enquanto em 2015 as intensidades máximas se limitaram a cerca de 20000 a $25000 \mathrm{~W} / \mathrm{m}$.

Em 2016 ocorreu a entrada de uma forte frente fria no fim do mês de agosto, que gerou inundação do calçadão e das ruas próximas as praias. Nas figuras deste ano os picos de energia referentes a essa data se destacam, sendo bem mais intensos que outros picos apresentados. No ponto S12 de Santos, o valor chegou perto de $25000 \mathrm{~W} / \mathrm{m}$, que corresponde aos máximos valores encontrados em todo o arco praial no ano de 2015. 

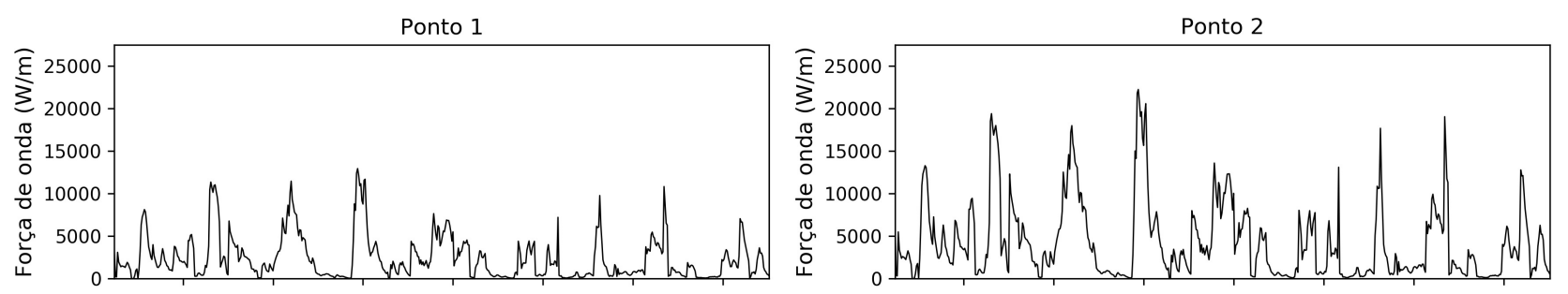

Ponto 3
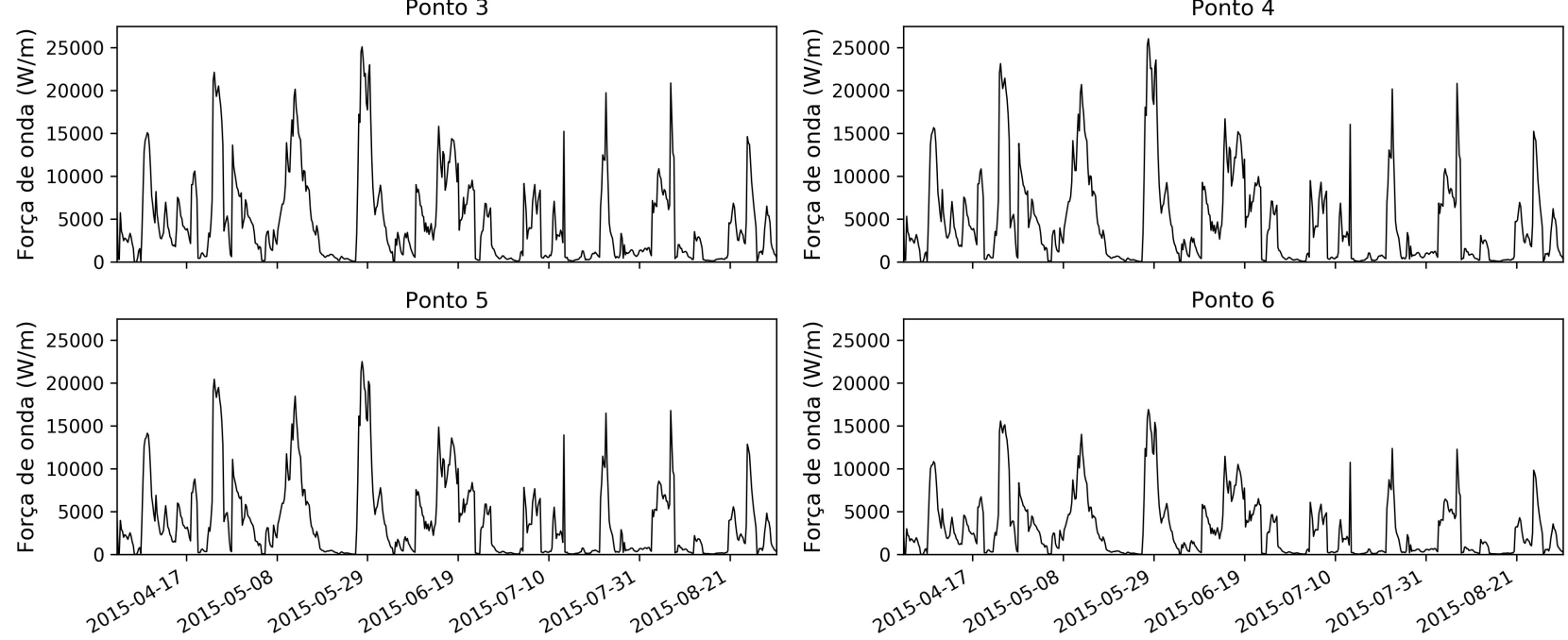

Figura 5.13: Série temporal da Força de Onda calculada através dos resultados de ondas do modelo Delft-3D Wave, no seis pontos de extração em Itararé no ano de 2015.

Na praia de Itararé foram realizados levantamentos topográficos apenas em 2016, que estão representados na Figura 5.14 como estrelas. A observação dos dias que antecedem cada levantamento, permite avaliar a intensidade da ação das ondas em cada ponto. O período que antecede o primeiro levantamento (06/07/16) apresenta menor força de onda, indicando um período calmo. Já o período antes do segundo levantamento (26/08/16) apresentou uma força de onda mais intensa com dois picos maiores. O período entre o segundo e o terceiro (30/09/16) levantamentos foi marcado por dois grandes picos, refletindo duas frentes frias mais intensas que atingiram a região. A semana que antecedeu o levantamento do 30/09, também mostrou eventos mais intensos, indicando que a praia não teve tempo para se recuperar da entrada das duas frentes frias anteriores. O último levantamento (02/11/16) foi antecedido por um período de calmaria, com picos baixos de força de onda. 

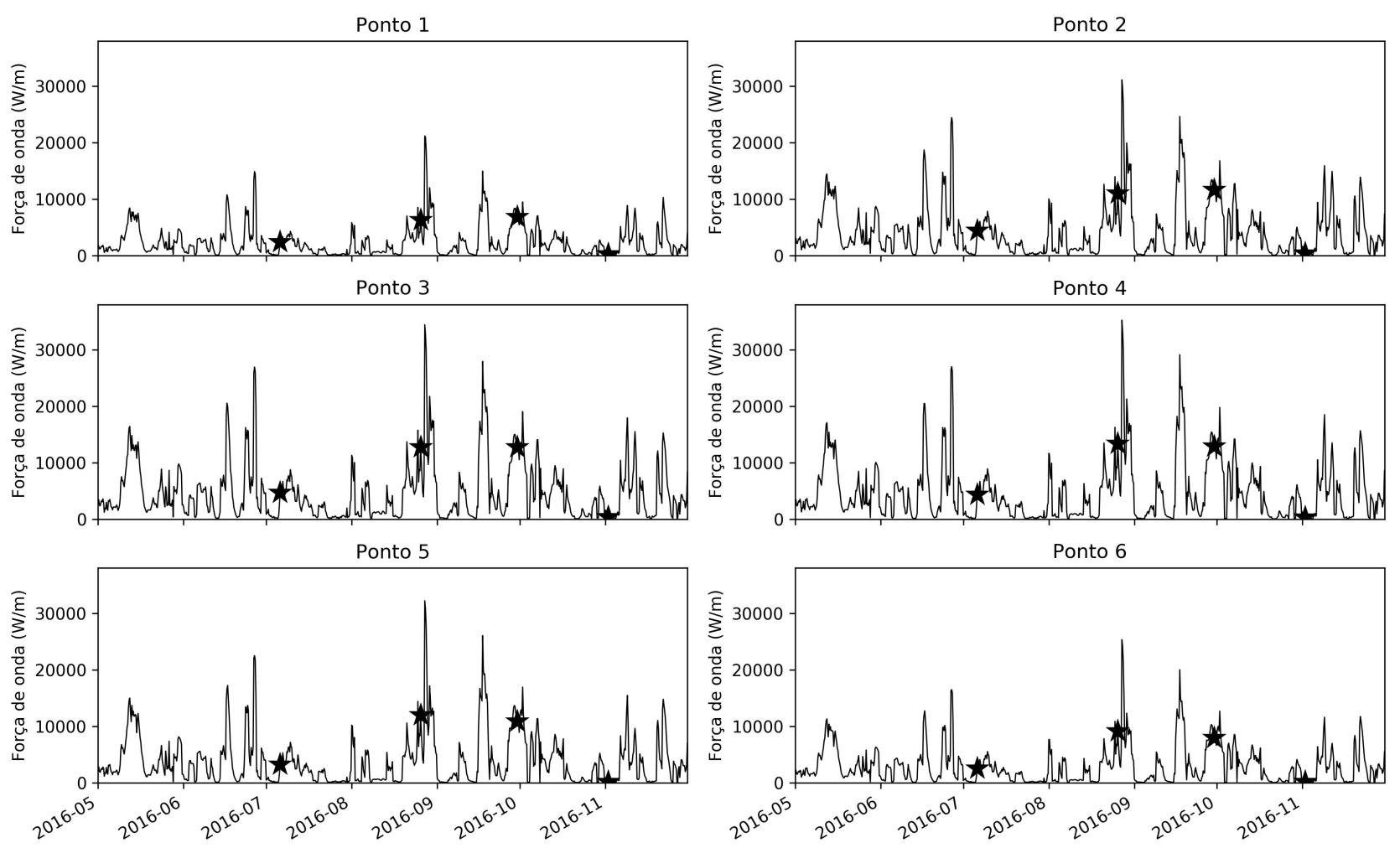

Figura 5.14: Série temporal da Força de Onda calculada através dos resultados de ondas do modelo Delft-3D Wave, no seis pontos de extração em Itararé no ano de 2016. Nesta imagem os dias com levantamento topográfico estão indicados com uma estrela.

Em Santos foram realizados levantamentos de campo em 2015 e 2016, as datas estão representadas com estrelas nas Figuras 5.15 e 5.16. Como já vimos anteriormente o ano de 2015 teve menos eventos de frentes frias que 2016. Entretanto, pode-se observar alguns picos de força de onda que pode ter causado mudanças na praia de Santos. Entre o primeiro (22/04/15) e o segundo (22/05/15) levantamentos observa-se dois picos de força de onda, contudo, os dias que antecederam o segundo trabalho de campo mostram uma queda na energia de onda para valores muito baixos, indicando um período menos energético. Os dias que antecederam o levantamento do 08/06/15 mostram uma pequena ação da onda com a presença de força de onda baixa, mas existente. No período entre o terceiro e o quarto (26/06/15) trabalho de campo a força de onda é mais intensa, com valores acima de $10000 \mathrm{~W} / \mathrm{m}$. Contudo, o penúltimo levantamento (22/07/15) foi logo após um período longo de calmaria, em que as ondas tiveram pouca força. Os dias que antecederam o levantamento de 07/08/15 já apresentaram ondas mais intensas. 

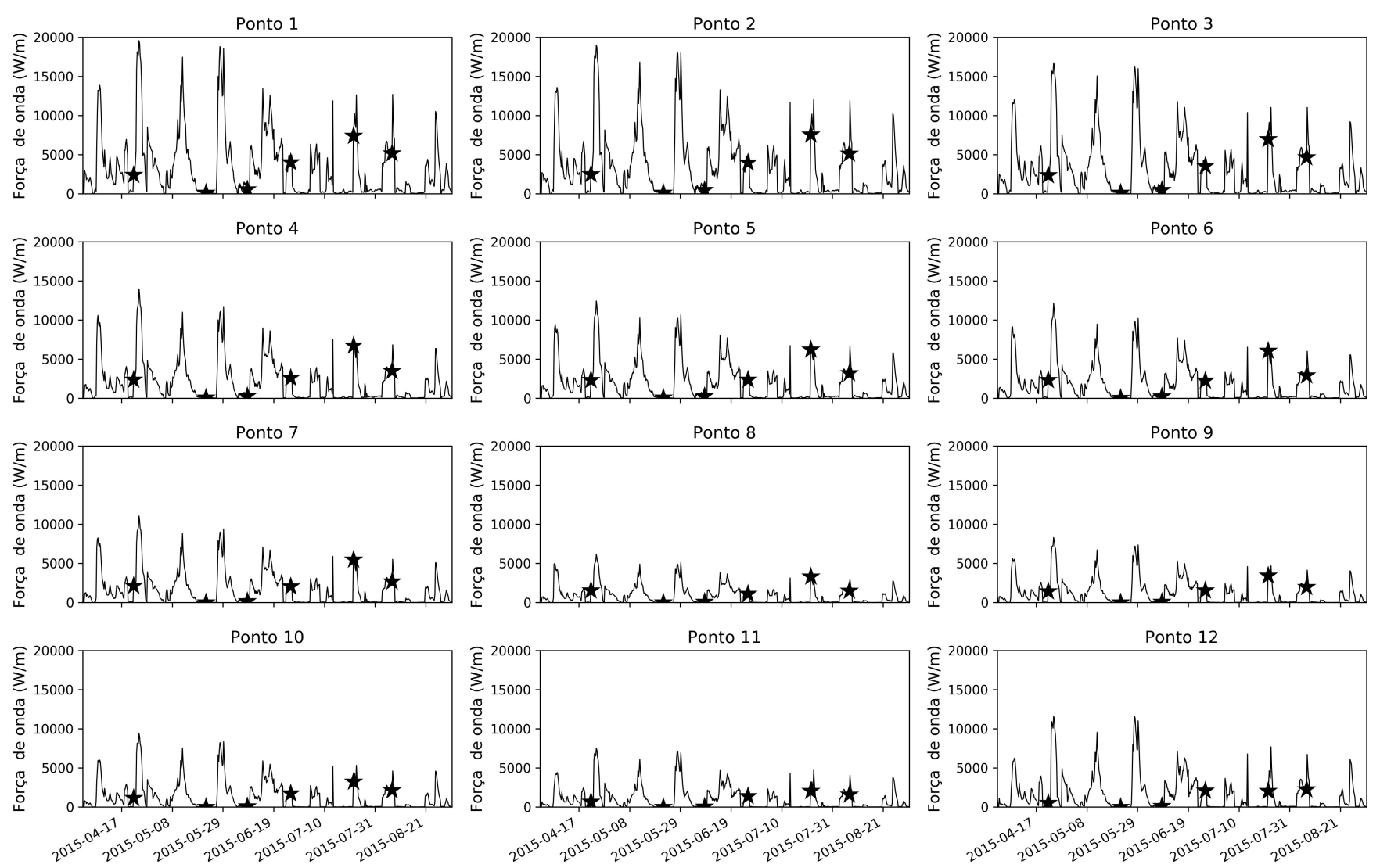

Figura 5.15: Série temporal da Força de Onda calculada através dos resultados de ondas do modelo Delft-3D Wave, no doze pontos de extração em Santos no ano de 2015. Nesta imagem os dias com levantamento topográfico estão indicados com uma estrela.

No ano de 2016 a ação das ondas foi mais significativa, devido a maior entra de frentes frias na costa sudeste, atingindo intensamente a região costeira de Santos. A força de onda do período que antecedeu o primeiro levantamento (27/05/16) não se mostrou muito intensa, mas apresentou valores relevantes, enquanto no segundo (06/07/16) observam-se valores de força de onda ainda mais baixos. O levantamento de 26/08/16 apresentou força de onda mais intensa com picos maiores, a partir dessa data observou-se que a força de onda dos eventos energéticos passou a ter maior intensidade. O período entre o terceiro e o quarto (30/09/16) levantamento foi marcado por dois grandes picos, representando duas fortes frentes que atingiram a costa nesse período. Nos dias mais próximos do levantamento do 30/09 não havia mais a ação dessas duas frente, contudo, a energia da onda era alta. O último levantamento (02/11/16) foi antecedido por período com picos menores de força de onda, contudo, os dias logo antes do levantamento topográfico apresentaram dois picos menores, mas relevantes. 

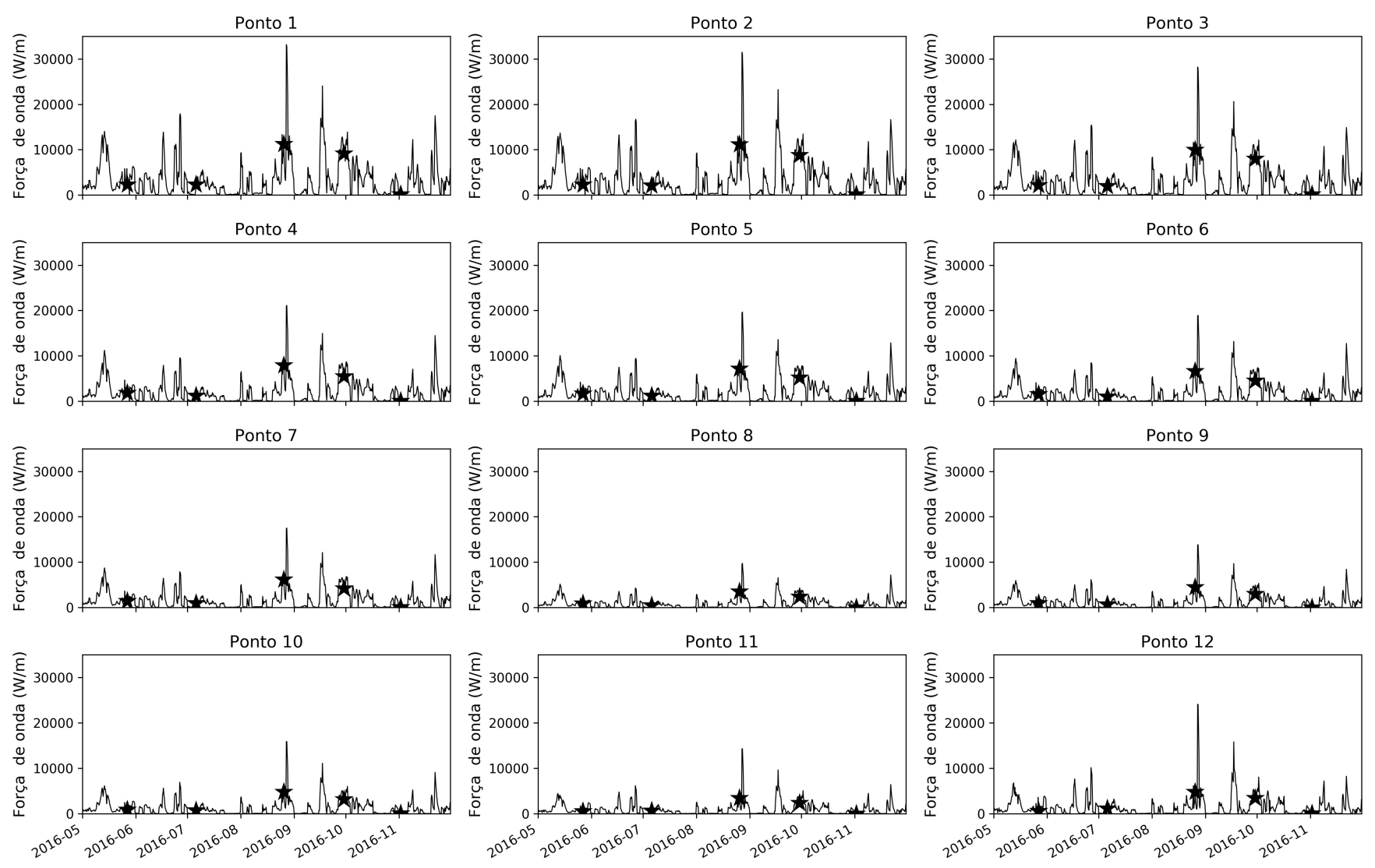

Figura 5.16: Série temporal da Força de Onda calculada através dos resultados de ondas do modelo Delft-3D Wave, no doze pontos de extração em Santos no ano de 2016. Nesta imagem os dias com levantamento topográfico estão indicados com uma estrela.

\subsubsection{Morfologia}

A partir dos mapas digitais de terreno, obtidos através dos levantamentos de campo, foi possível realizar a estimativa volumétrica para cada caminhamento referente aos 11 levantamentos morfológicos realizados em Santos e os 4 levantamentos realizados em Itararé.

Nos modelos digitais de terreno (MDT), como os da Figura 5.17, é possível observar os trechos da praia que podem estar mais sujeitos a erosão. O trecho central e o extremo oeste da praia de Santos são mais largos, aproximadamente 190 m e 170 m respectivamente, que o trecho leste (aproximadamente $110 \mathrm{~m}$ ), esses trechos são também os que possuem alturas topográficas maiores, atingindo cerca de $2.6 \mathrm{~m}$, que os trechos mais estreitos, que por ter uma menor largura e alturas mais baixas (cerca de $1.8 \mathrm{~m}$ ) podem ser mais afetadas por erosão. Modelo digital de terreno de Itararé nos mostra que a parte leste, próxima ao emissário, é mais protuberante que o restante da praia, devido ao efeito de sombra causado pela ilha Urubuqueçaba. Devido a ação desse processo, essa porção da praia apresenta alturas topográficas maiores, causadas pela alta deposição de sedimento no local. O restante da praia apresenta largura e alturas topográficas mais homogêneas. 


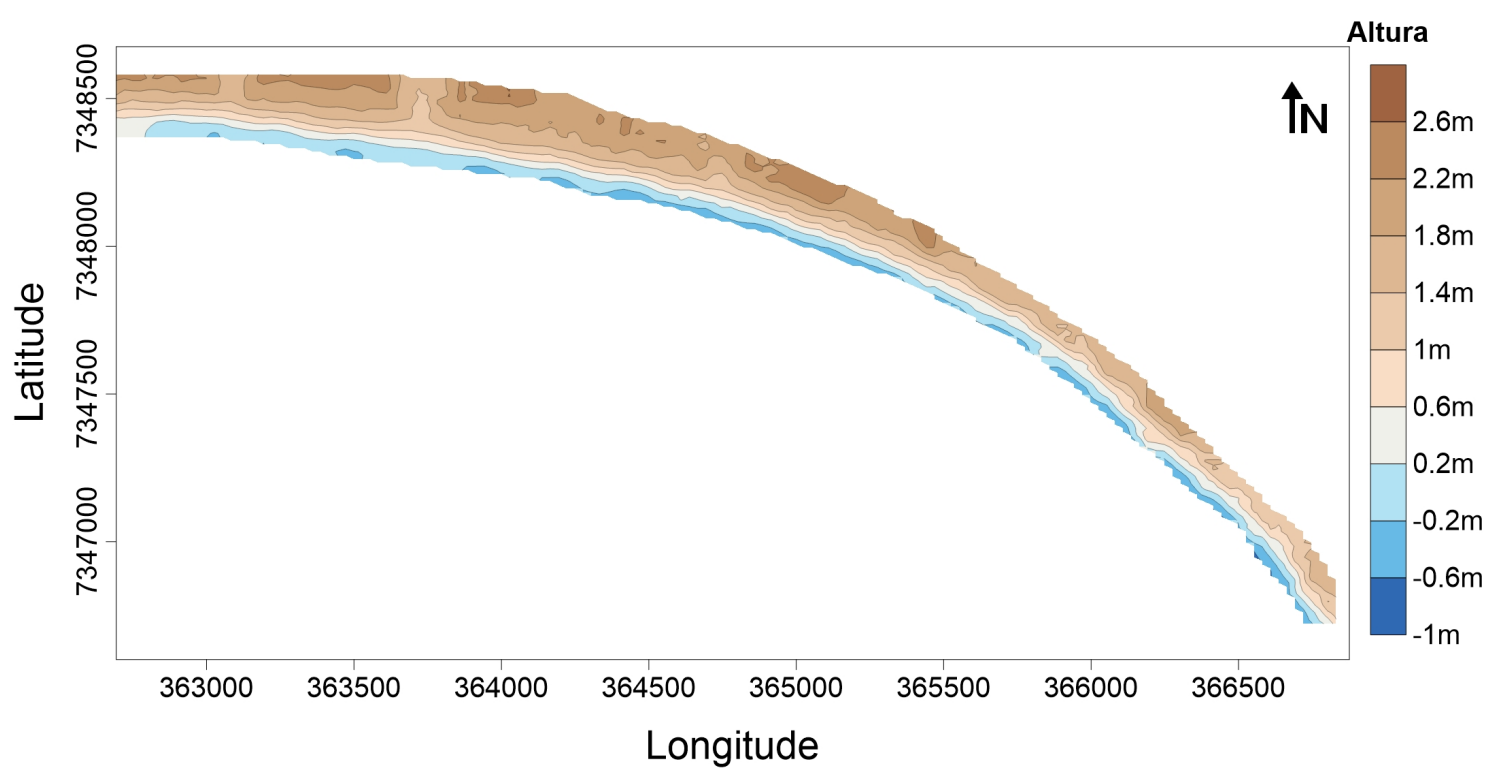

(a)

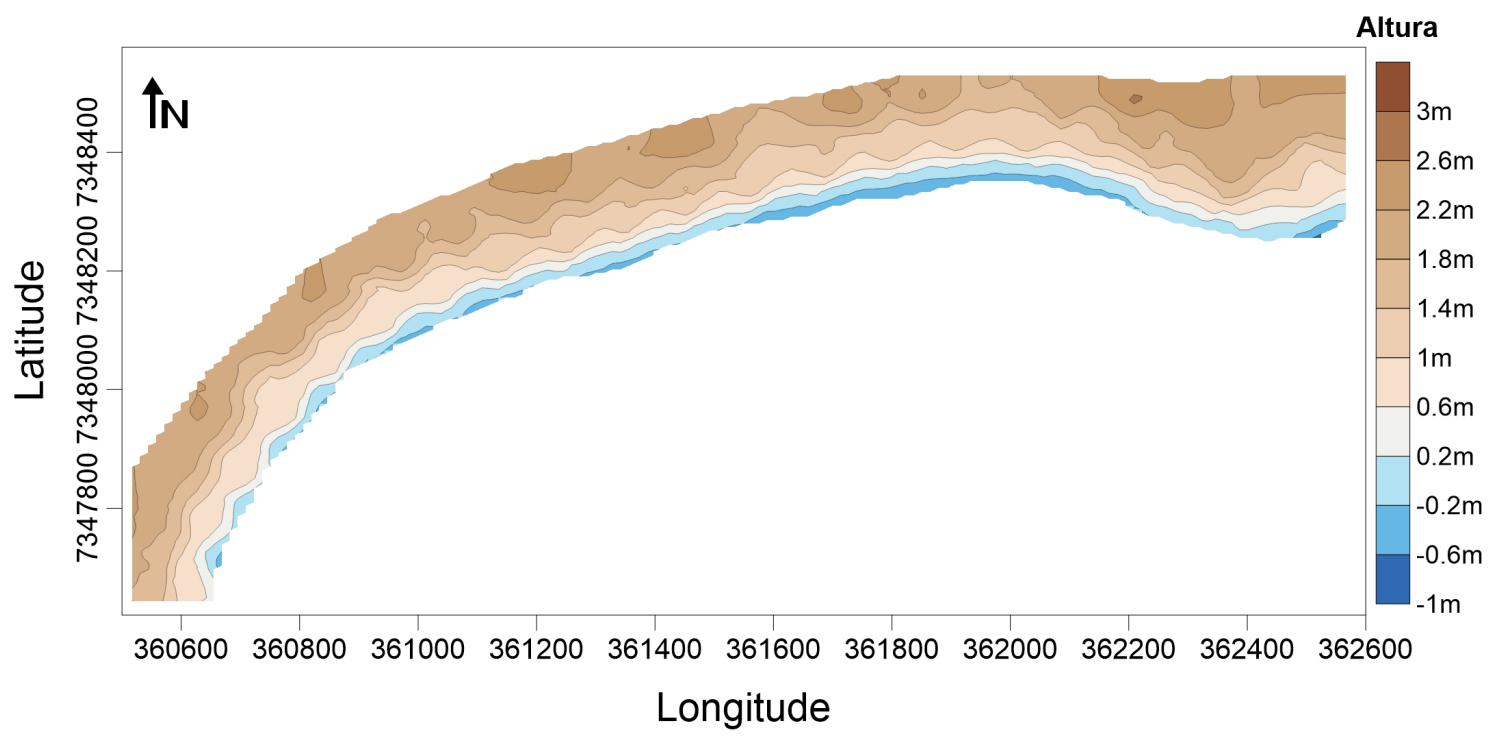

(b)

Figura 5.17: Modelo digital de terreno indicando a topográfica da praia no dia do levantamento a) Santos - levantamento de 22/04/2015. b) Itararé - levantamento de 06/07/16.

A Figura 5.18, representa a diferença entre o primeiro e o último levantamento dos anos de 2015 e 2016 em ambas as praias da baía de Santos. Comparando ambos MDTs de Santos se observa que a perda de altura é bem mais visível no MDT de 2016, apesar de também notarmos valores negativos no MDT de 2015. Em 2016, na porção oeste de Santos houve uma maior perda de volume no pós-praia, enquanto o centro da praia e o trecho leste sofreram perdas mais localizadas na face praial. Assim identifica-se respostas diferentes desses trechos aos processos causados pelos eventos de tempestade, na praia de Santos. Podemos observar no MDT de Itararé, assim como nos de Santos, que a praia sofreu perda de sedimento ao longo do período estudado. A redução de altura está concentrada principalmente na face praial em 
Itararé. Entretanto, no pós-praia notamos altura positivas, indicando acréscimo de sedimento ao longo de todo o pós-praia de Itararé.

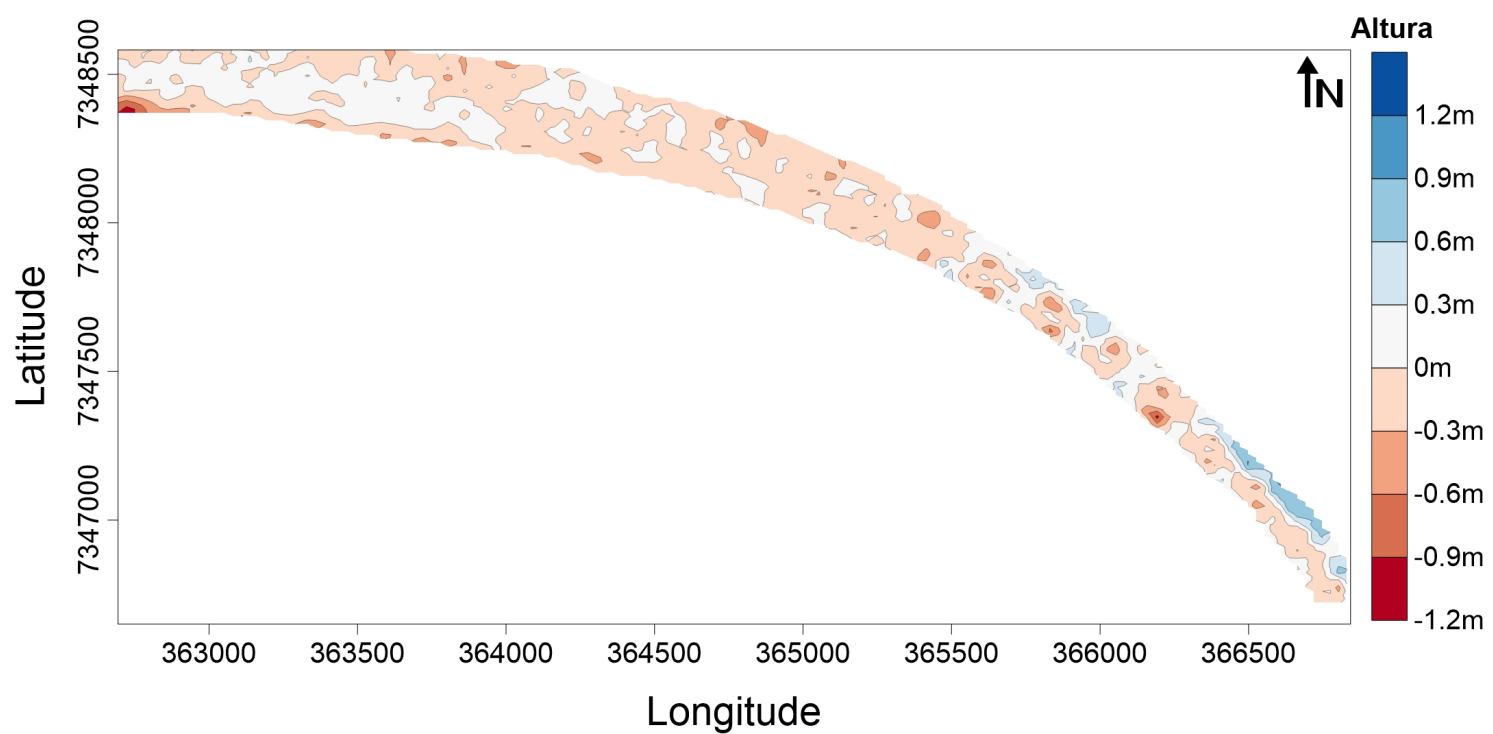

(a)

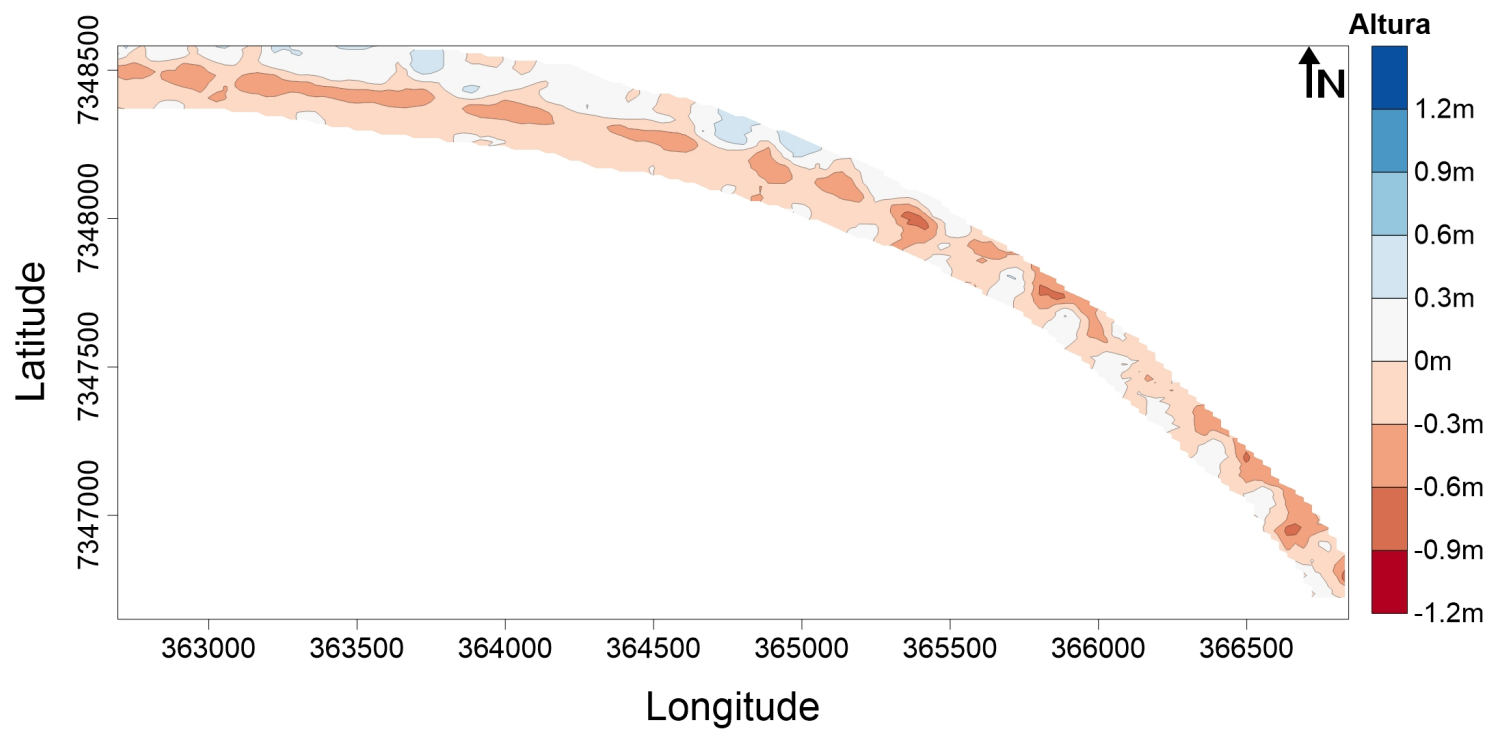

(b)

Figura 5.18 (Continua) 


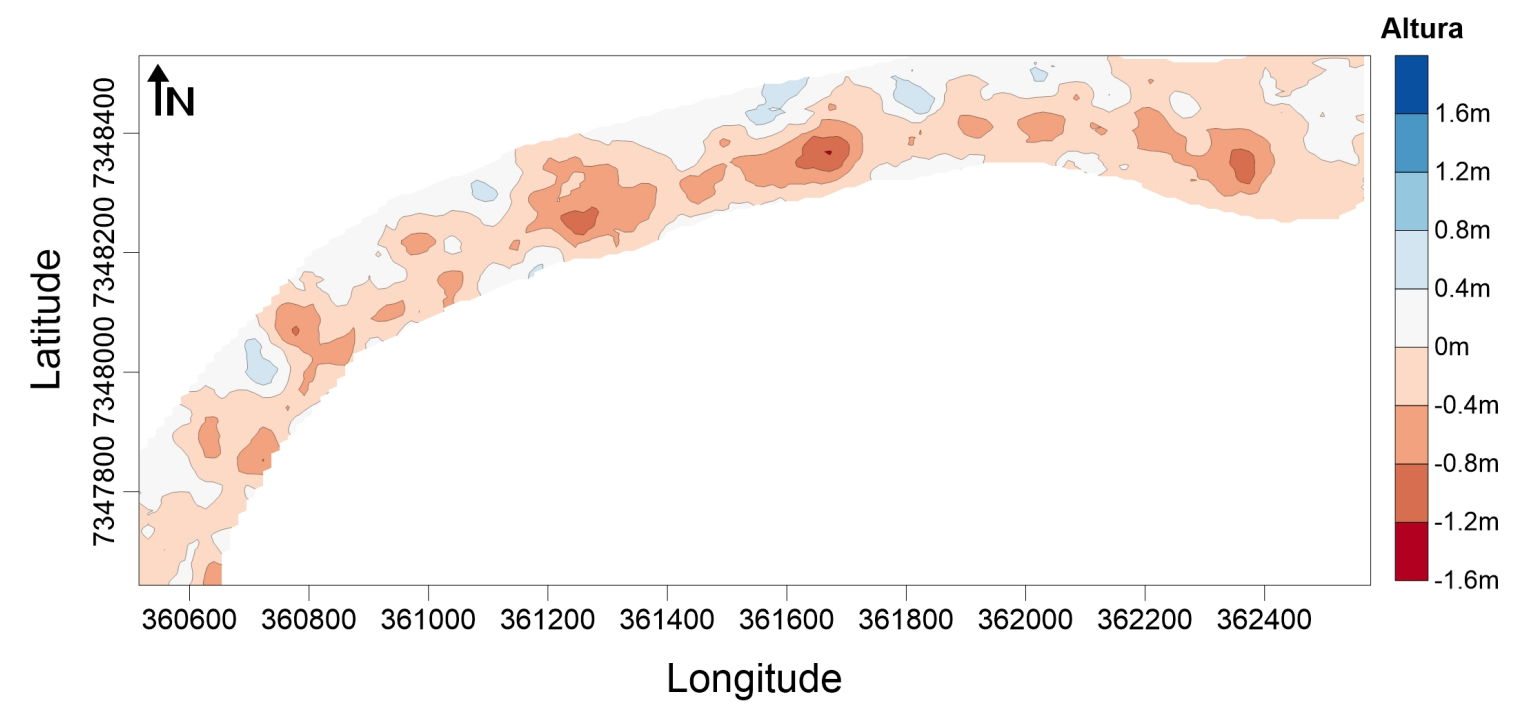

(c)

Figura 5.18: (Continuação) Modelo digital de terreno, mostrando a variação na topografia, em metros, entre o primeiro e o último campo a) Santos - 2015: Entre os levantamentos de 22/04/15 e 22/05/15 b) Santos - 2016: Entre os levantamentos de 27/05/16 e 02/11/16 c) Itararé - 2016: Entre os levantamentos de 06/07/16 e 02/11/16, em metros.

As alterações entres os levantamentos de campo se apresentaram de formas diferentes ao longo da praia de Santos em 2015 (Figura 5.19) as mudanças entre os levantamentos de 22/0422/05 foram principalmente na porção leste da praia, onde se observa um aumento na altura do pós praia, na porção centro-oeste pouca variação é observada. Entre os levantamentos de 22/0508/06 a variação se apresentou mais negativa, indicando perda de sedimento ao longo de toda a praia. O trecho leste da praia apresenta os valores mais negativos, próximos a -0.9. A redução de altura se mostrou ainda mais intensa entre 08/06-26/06, ao longo da praia nota-se poucos trechos em que não houve variação de topografia e praticamente nenhuma área de acresção. No levantamento seguinte, em 22/07 houve recuperação do volume praial. É possível observar trechos da praia que apresentam valores positivos de altimetria. É interessante notar que porção mais a leste da praia que perdeu muita altura em 08/06, em 22/07 apresentou grande aumento na altura. No último levantamento de 2015 na data 07/08 foi observado na diferença de elevação entre campos valores negativos indicando perda de altura novamente ao longo de toda a praia. 


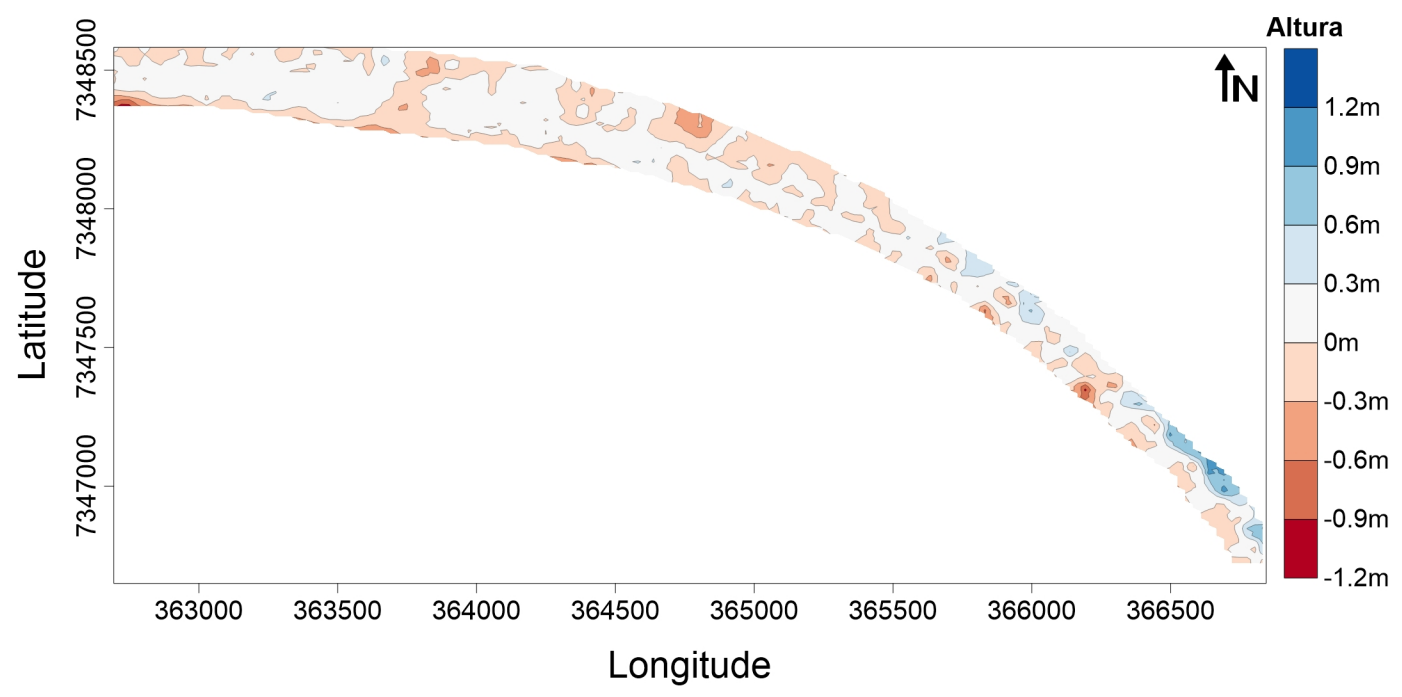

(a)

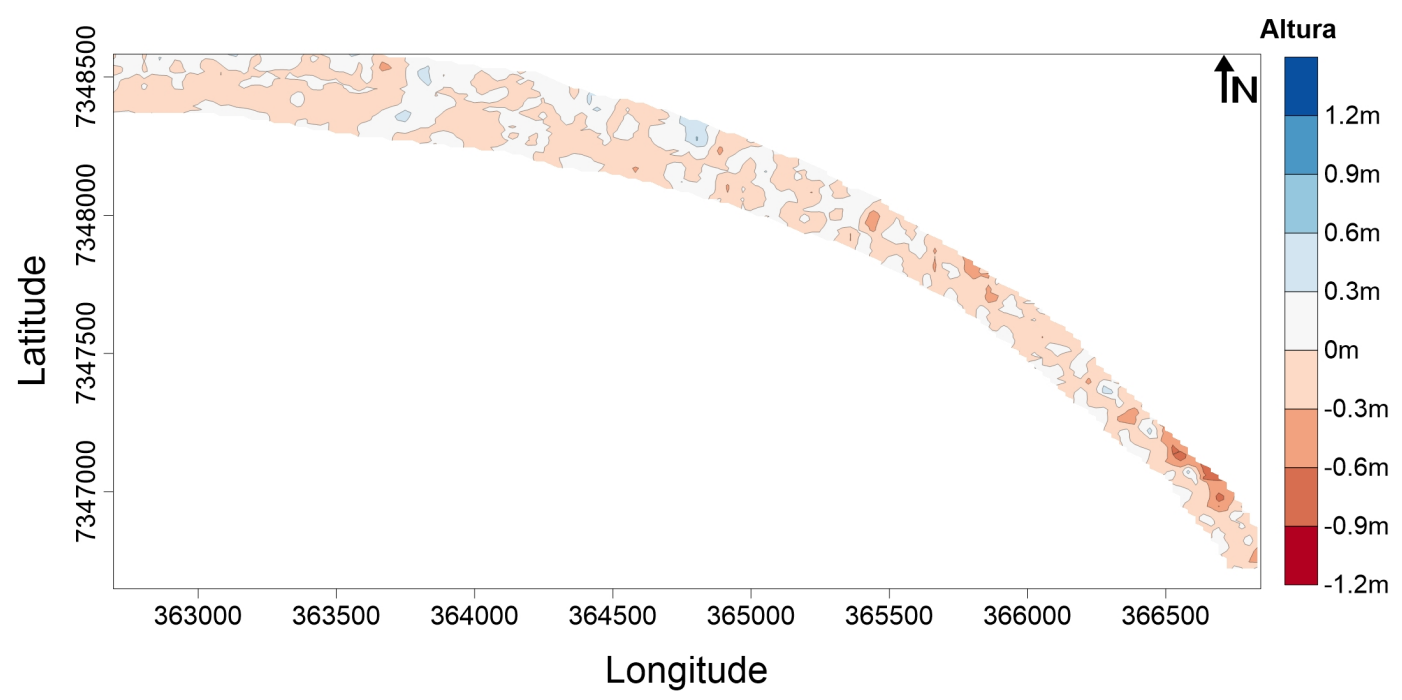

(b)

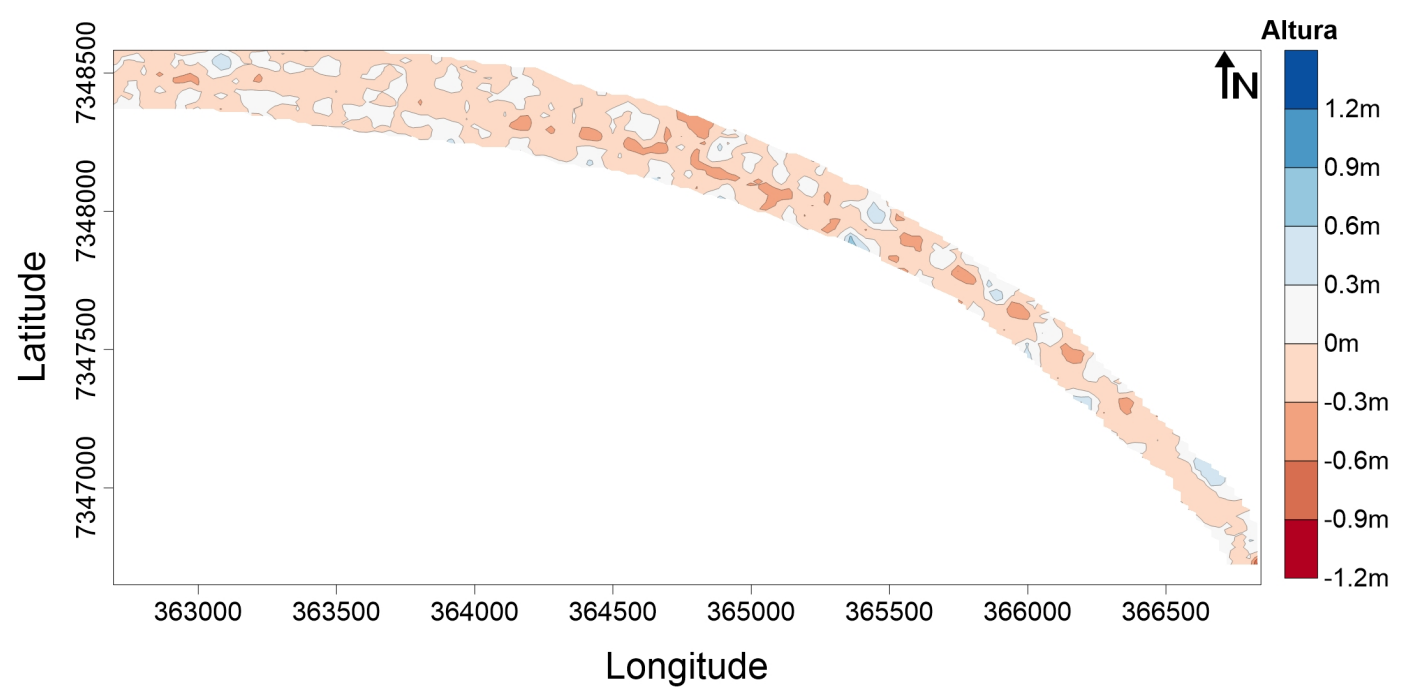

(c)

Figura 5.19 (Continua) 


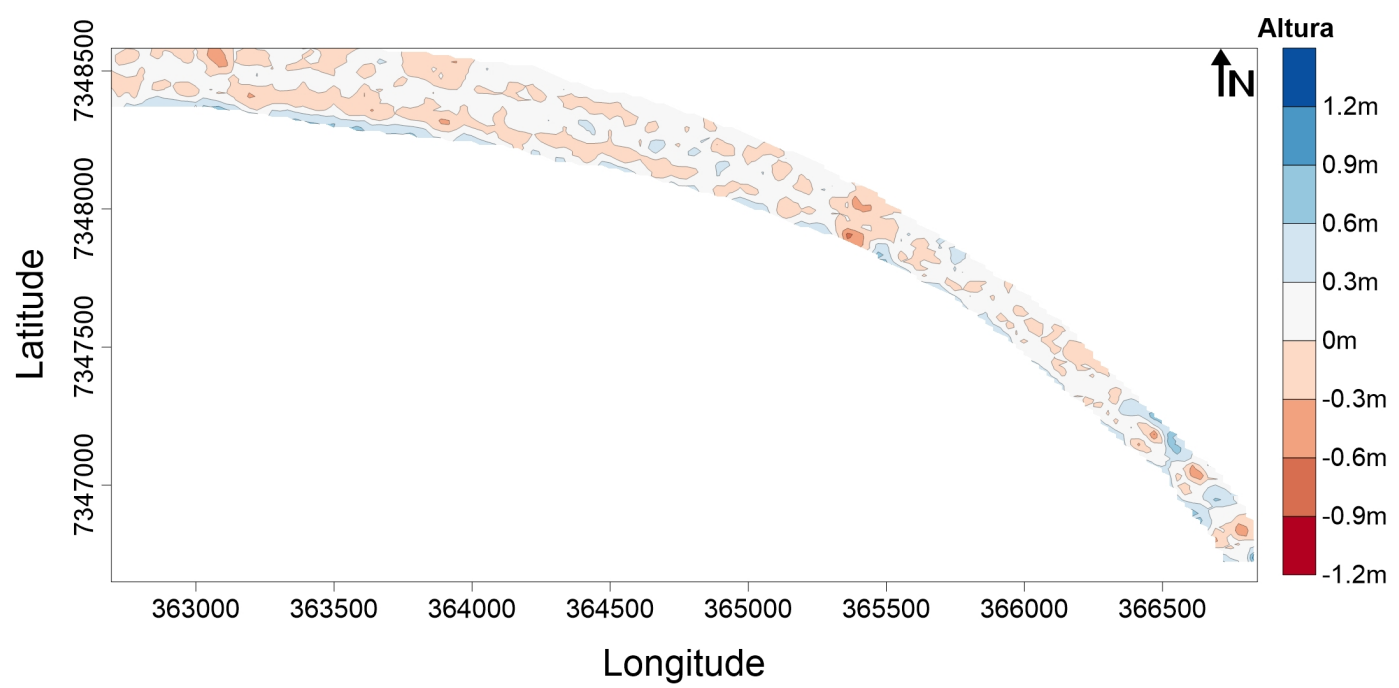

(d)

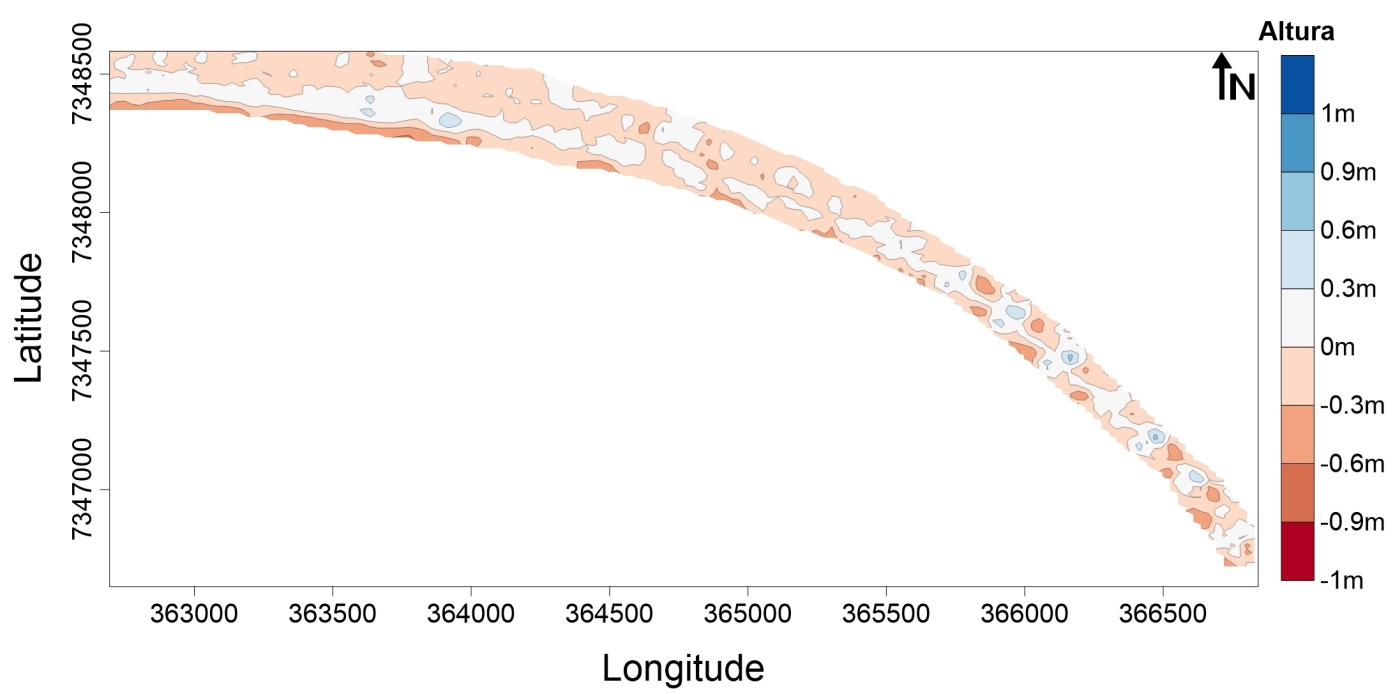

(e)

Figura 5.19: (Continuação) Modelo digital de terreno, mostrando a variação na topografia, em metros, entre os campos realizados no ano de 2015 em Santos. a) Entre os levantamentos de 22/04/15 e 22/05/15. b) Entre os levantamentos de 22/05/15 e 08/06/15. c) Entre os levantamentos de 08/06/15 e 26/06/15. d) Entre os levantamentos de 26/06/15 e 22/07/15. e) Entre os levantamentos de 22/07/15 e 07/08/15.

Da mesma forma, foi estimada também a diferença entre os levantamentos realizados em 2016 (Figura 5.20). A variação das diferenças morfológicas permite uma essa redução na altimetria da praia. Da mesma forma que em 2015, em 2016 as alterações se mostraram mais intensas na porção centro-oeste da praia de Santos. Entre 27/05-06/07 a praia sofreu poucas alterações, variando entre mais ou menos $0.3 \mathrm{~m}$ de altura apesar de apresentar alguns pontos de perda mais intensa da porção centro-leste que também apresentou pontos de maior ganho de altura. Entre 06/07-26/08 foi observado uma grande perda na altimetria, sendo esta mais intensa na porção leste. Entretanto, no levantamento do dia 30/09 nota-se uma pequena recuperação da praia principalmente na face praial da região centro-leste, o restante da praia sofre pouca varia- 
ção de altimetria entre os levantamentos. A diferença de elevação entre 30/09-02/11 apresenta valores mais negativos em toda a praia, com destaque para a face praial. Essas observações podem ser confirmadas com a análise da variação do volume estimado para os levantamentos topográficos realizados.

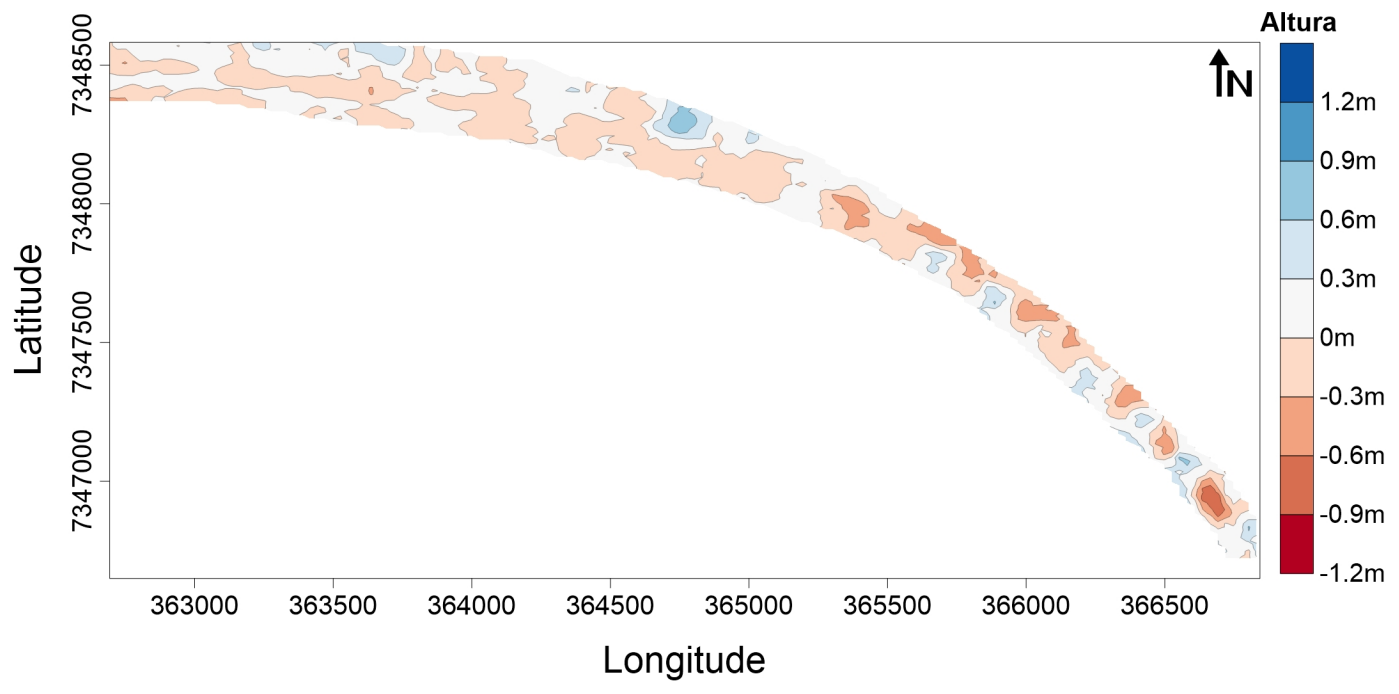

(a)

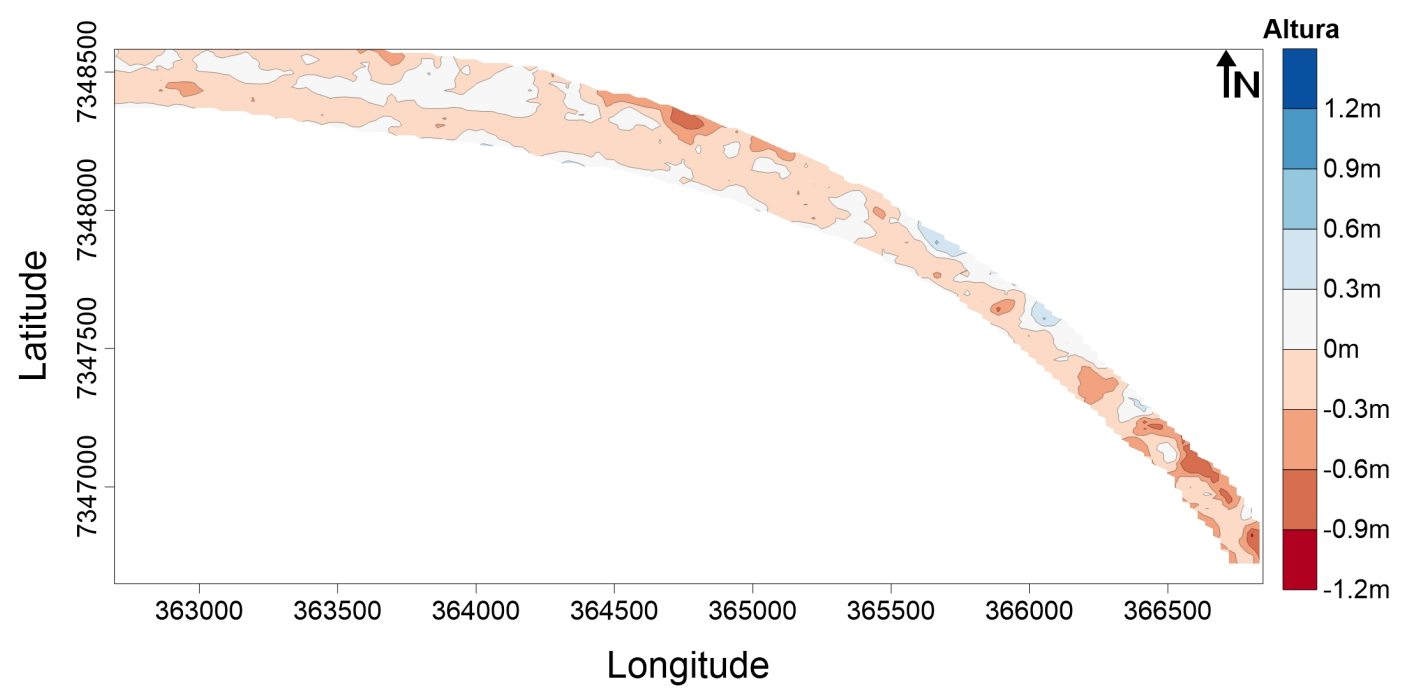

(b)

Figura 5.20 (Continua) 


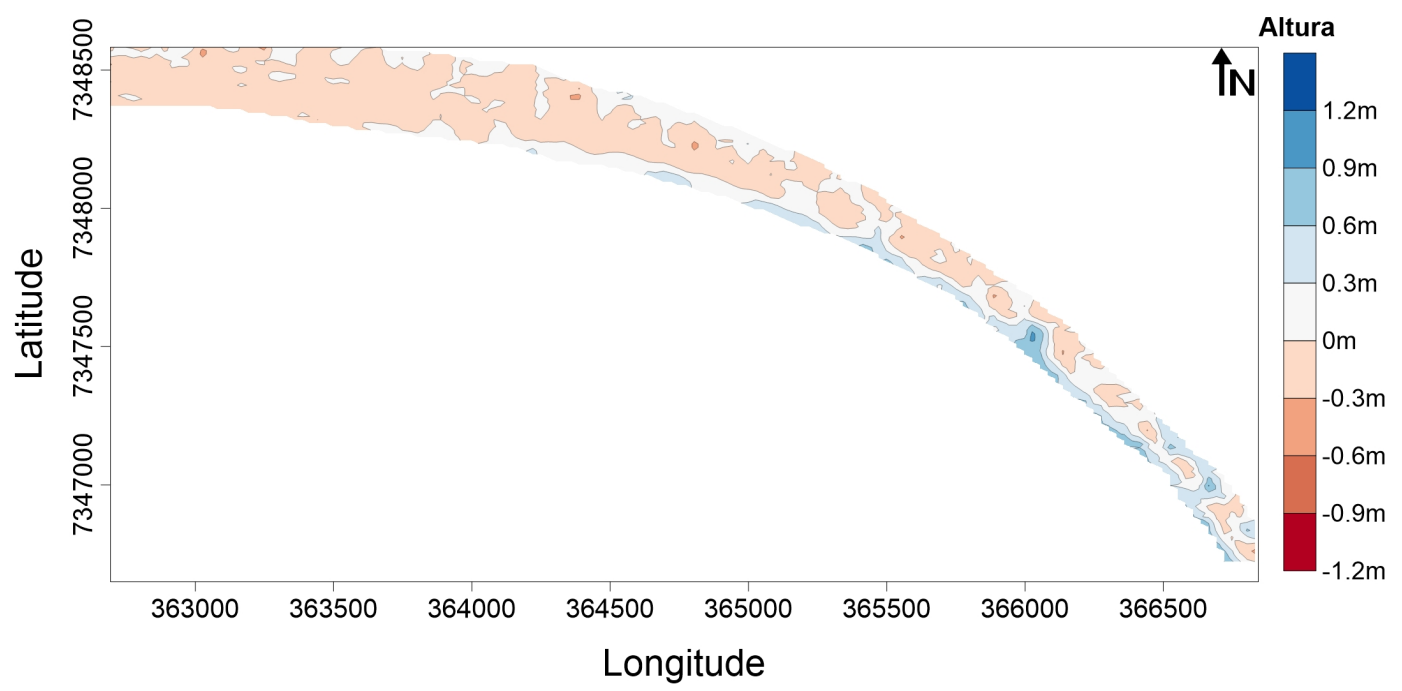

(c)

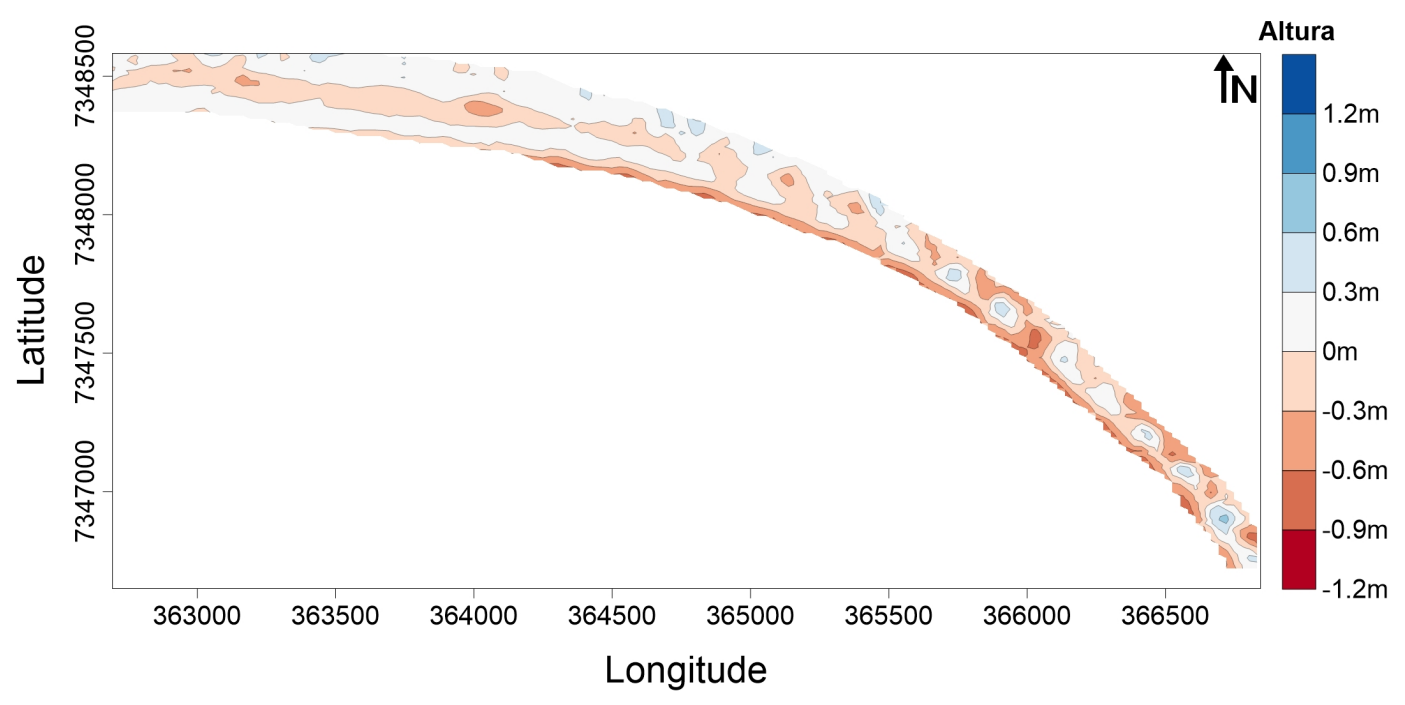

(d)

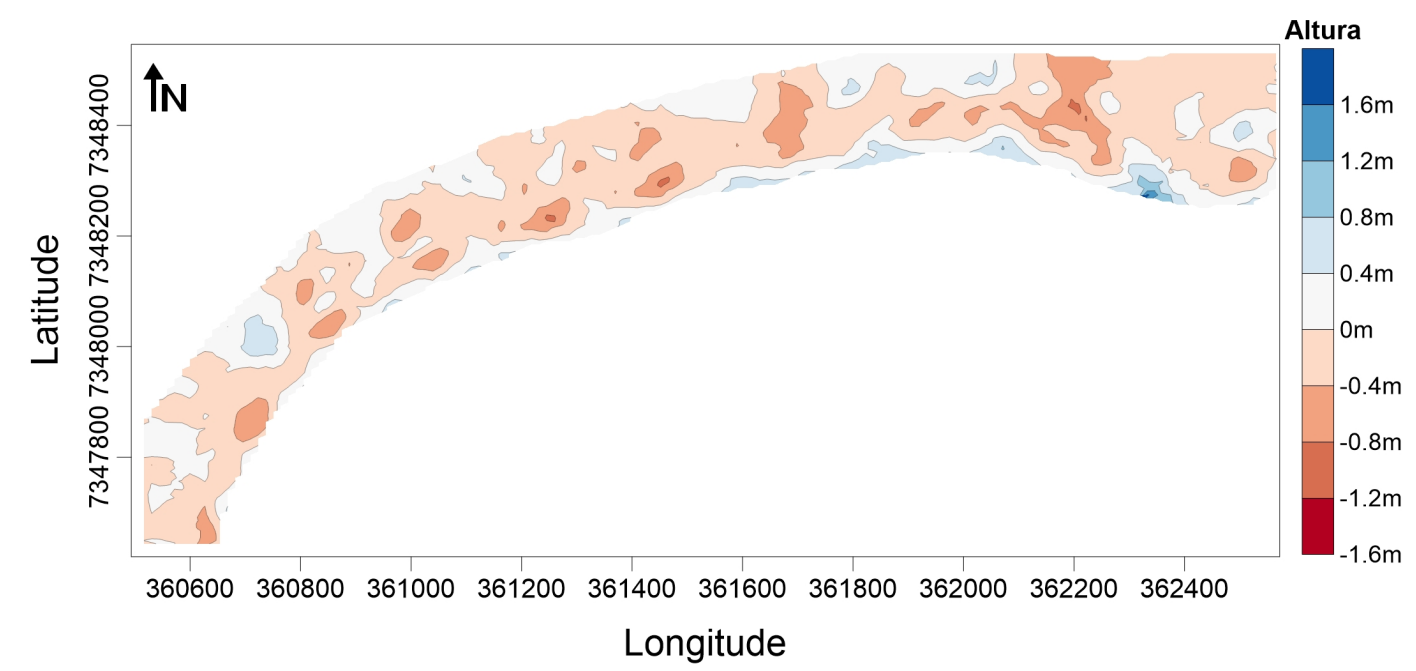

(e)

Figura 5.20 (Continua) 


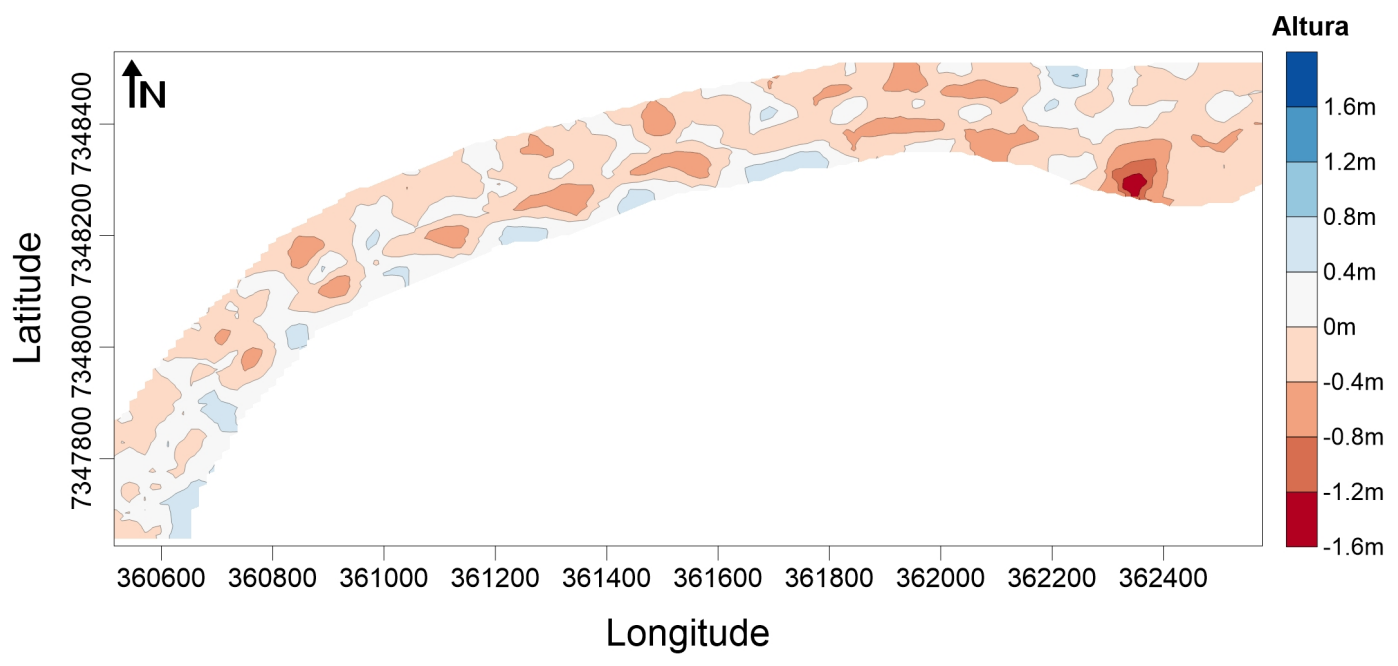

(f)

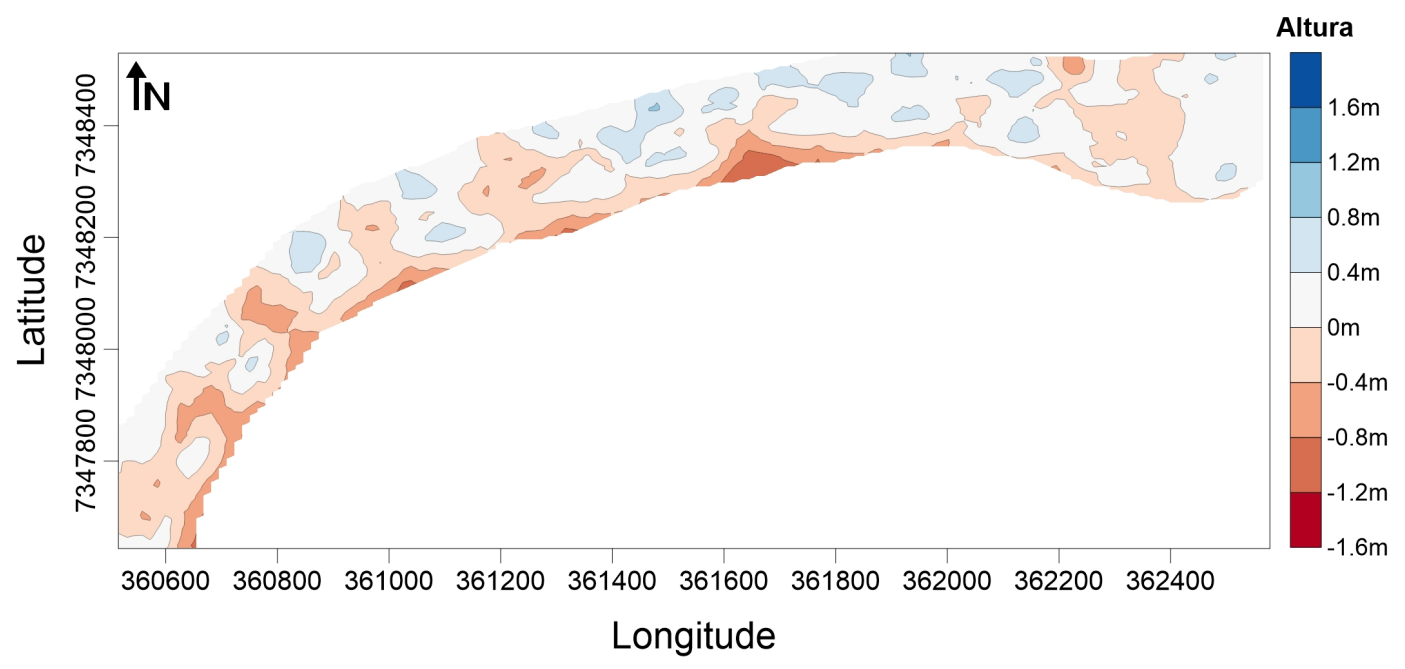

(g)

Figura 5.20: (Continuação) Modelo digital de terreno, mostrando a variação na topografia, em metros, entre os campos realizados no ano de 2016 em Santos e em Itararé. a) Santos: Entre os levantamentos de 27/05/16 e 06/07/16. b) Santos: Entre os levantamentos de 06/07/16 e 26/08/16. c) Santos: Entre os levantamentos de06/08/16 e 30/09/16. d) Santos: Entre os levantamentos de 30/09/16 e 02/11/16. e) Itararé: Entre os levantamentos de 06/07/16 e 26/08/16. f) Itararé: Entre os levantamentos de06/08/16 e 30/09/16. g) Itararé: Entre os levantamentos de 30/09/16 e 02/11/16.

A diferença entre os levantamentos realizados em Itararé estão, também, apresentados na Figura 5.20. No período entre o primeiro e o segundo levantamento topográfico na praia de Itararé (06/07/16 - 26/08/16), foi observado perda de altimetria ao logo de toda a praia. Contudo, os valores de perda de altura não foram tão intensos, apresentando variação de $-0.4 \mathrm{~m}$ e -0.8 $\mathrm{m}$ basicamente. Alguns trechos mostram ganho de altura, como a face praial da região centroleste. Entre os levantamentos de 26/08/16 e 30/09/16 também notamos um variação negativa da altimetria da praia, mas menos intensa que a observada entre o levantamentos anteriores. No MDT vemos mais trechos da praia em azul do que observamos no período anterior, indicando 
que a perda de sedimento entre o segundo e o terceiro trabalho de campo foi menor. Vamos ver uma recuperação da praia apenas no último levantamento dia 11/02/16. A variação entre o penúltimo e o último trabalho de campo mostra vários trechos com ganho altimétrico em toda a praia, principalmente na região leste onde tem a zona de sobra da ilha.

Os volumes de ambas as praias também foram estimados. Os volumes da praia de Santos estão representados na Figura 5.21, e de forma geral os valores de 2016 são menores que em 2015. Os três últimos campos de 2016 apresentaram volumes menores que $1.6 \times 10^{6} \mathrm{~m}^{3}$, enquanto em 2015 apenas o campo de 26 de junho teve volume menor que $1.6 \times 10^{6} \mathrm{~m}^{3}$. Os maiores volumes são vistos em 22 de maio de 2015 e 22 de julho de 2015 , cerca $1.67 \times 10^{6} \mathrm{~m}^{3}$. Em agosto e novembro de 2016 observa-se volumes abaixo de $1.57 \times 10^{6} \mathrm{~m}^{3}$, sendo que o menor volume corresponde a novembro com cerca de $1.53 \times 10^{6} \mathrm{~m}^{3}$.

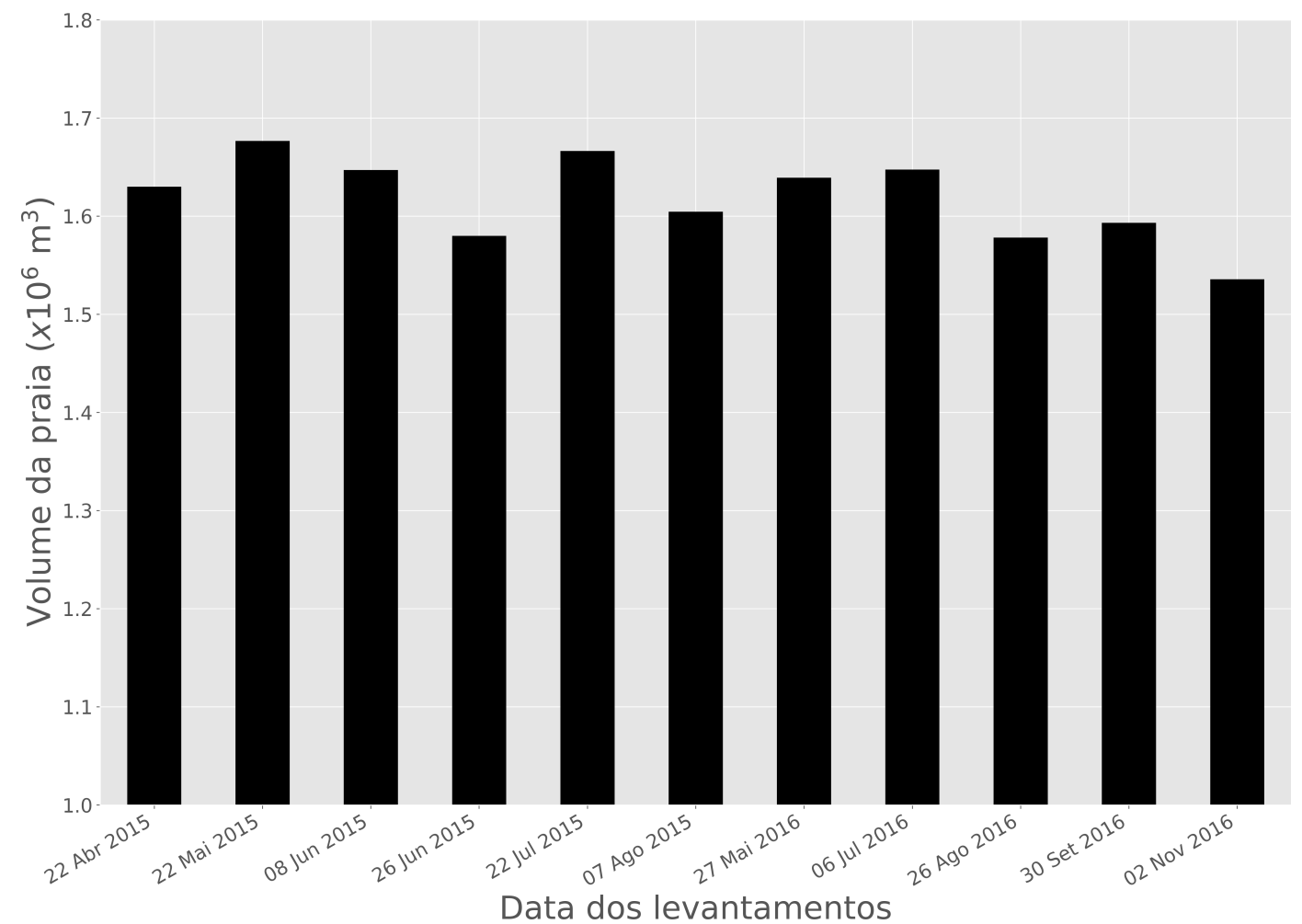

Figura 5.21: Gráfico do volume total dos caminhamentos realizados em cada levantamento de campo em Santos, indicando o eixo y em $1 \times 10^{6} \mathrm{~m}^{3}$.

A variação do volume de Santos pode ser melhor observada no gráfico da diferença de volume calculada entre os modelos digitais de terreno de cada levantamento topográfico (Figura 5.22). Nesse gráfico é possível observar que nos entre os primeiros levantamentos de 2015 houve pouca variação no volume (+2.9\% entre os dois primeiros levantamentos e $-1.8 \%$ entre o segundo e o terceiro levantamentos). Entretanto, nos meses mais energéticos a variação entre os campos aumentou para $-4.1 \%$ entre os levantamentos de junho, $+5.5 \%$ entre junho e julho e $3.7 \%$ entre julho e agosto. É interessante notar que após um levantamento no qual ocorreu perda de volume, no levantamento seguinte este volume tende a ser recuperado, devido ao processo de recuperação da praia após a passagem de frentes frias. Contudo, no final de 2016 a praia 
parece não conseguir recuperar o volume perdido. A variação entre os levantamentos de maio e julho indicou acréscimo de sedimento pequeno de $0.5 \%$, segundo de uma perda de volume de $-4.2 \%$ em agosto. $\mathrm{O}$ mesmo é observado entre agosto e setembro que a recuperação é de apenas $+1 \%$ e seguida de perda de volume novamente em novembro.

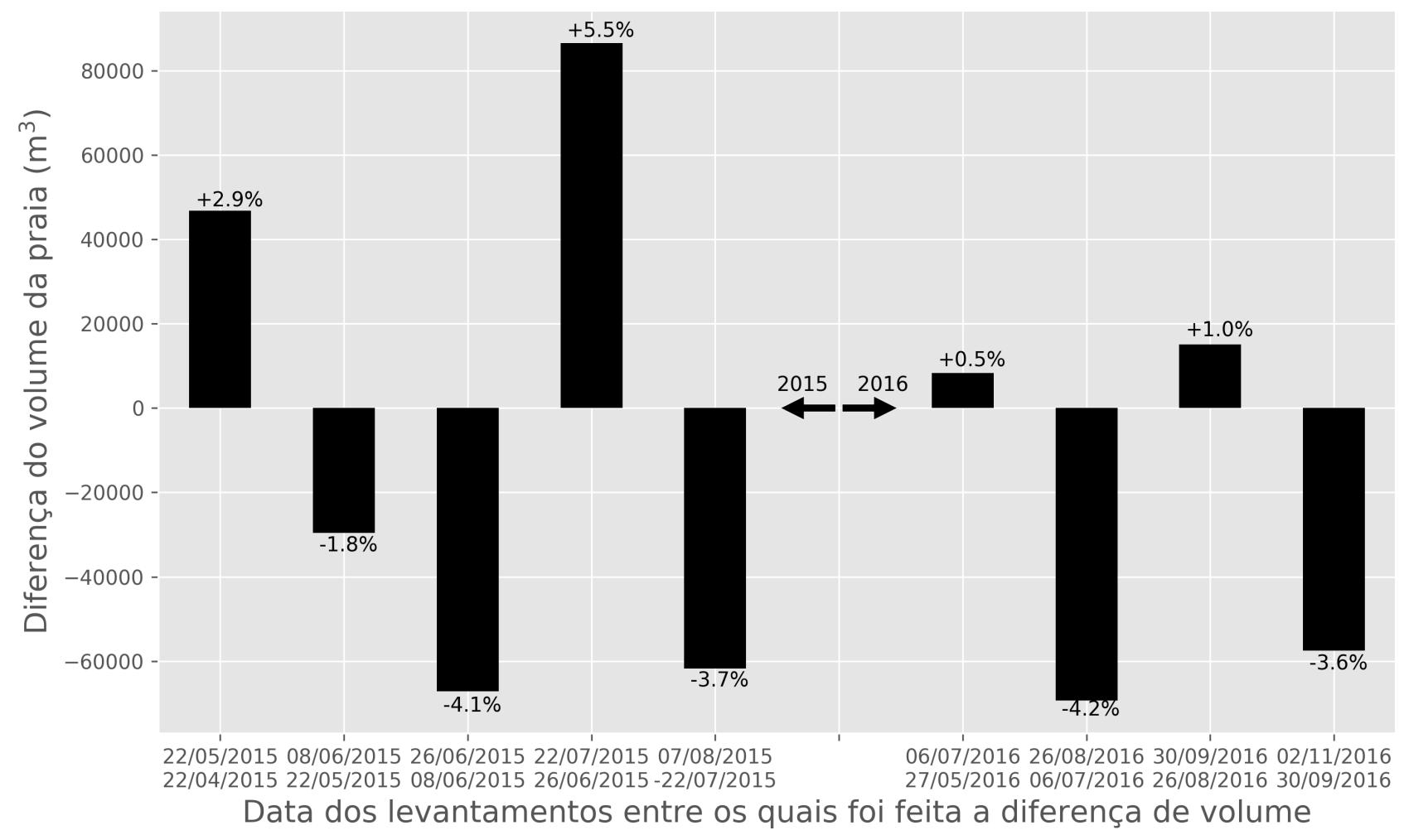

Figura 5.22: Diferença de volume entre os levantamento topográficos em Santos, realizados nos anos de 2015 e 2016.

O volume calculado dos levantamentos de campo em Itararé (Figura 5.23) reforça as observações dos MDTs. No dia 06/07/16 foi registrado o maior volume praial dentro do período estudado, cerca de $7.4 \times 10^{5} \mathrm{~m}^{3}$. O volume da praia apresenta uma tendência de queda nos levantamentos seguintes, o menor volume obtido foi no dia $30 / 09 / 16$, igual a $6.6 \times 10^{5} \mathrm{~m}^{3}$. No penúltimo levantamento o volume encontrado foi aproximadamente $6.8 \times 10^{5} \mathrm{~m}^{3}$, mostrando uma pequena recuperação. Como observado, notamos que a praia sofreu perda de volume tanto entre o primeiro e segundo campo (07/06/16 e 26/08/16) quanto entre o segundo e o terceiro (26/08/16 e 30/09/16) e uma pequena recuperação de volume indicada pelo último levantamento. As variações foram de $-6.0 \%,-5.1 \%$ e $+2.5 \%$ respectivamente (Figura 5.24). Portanto, ao longo do período observado, a praia de Itararé sofreu perda de sedimento. Indicando que a praia de Itararé também está suscetível aos eventos energéticos. 


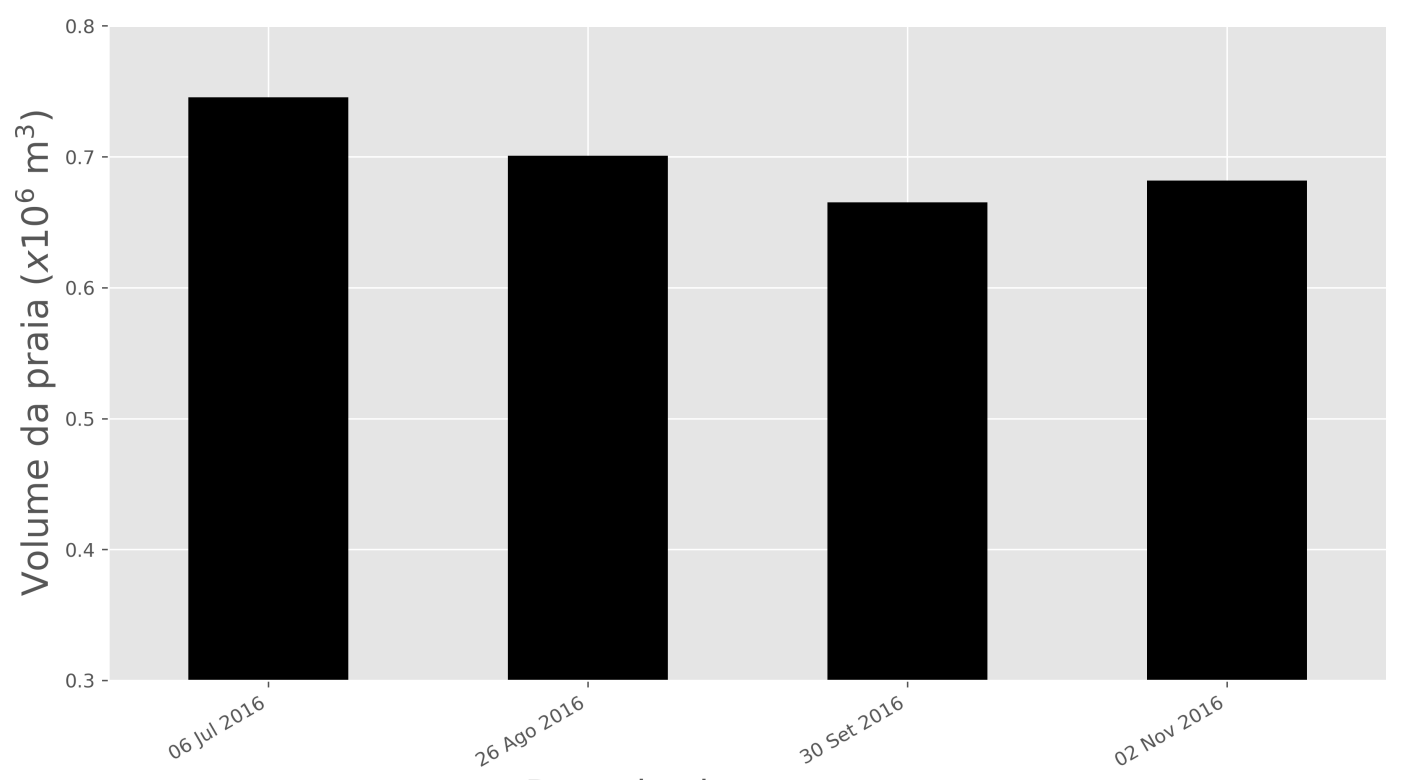

Data dos levantamentos

Figura 5.23: Gráfico do volume total dos caminhamentos realizados em cada levantamento de campo em Itararé, indicando o eixo y em $1 \times 10^{5} \mathrm{~m}^{3}$.

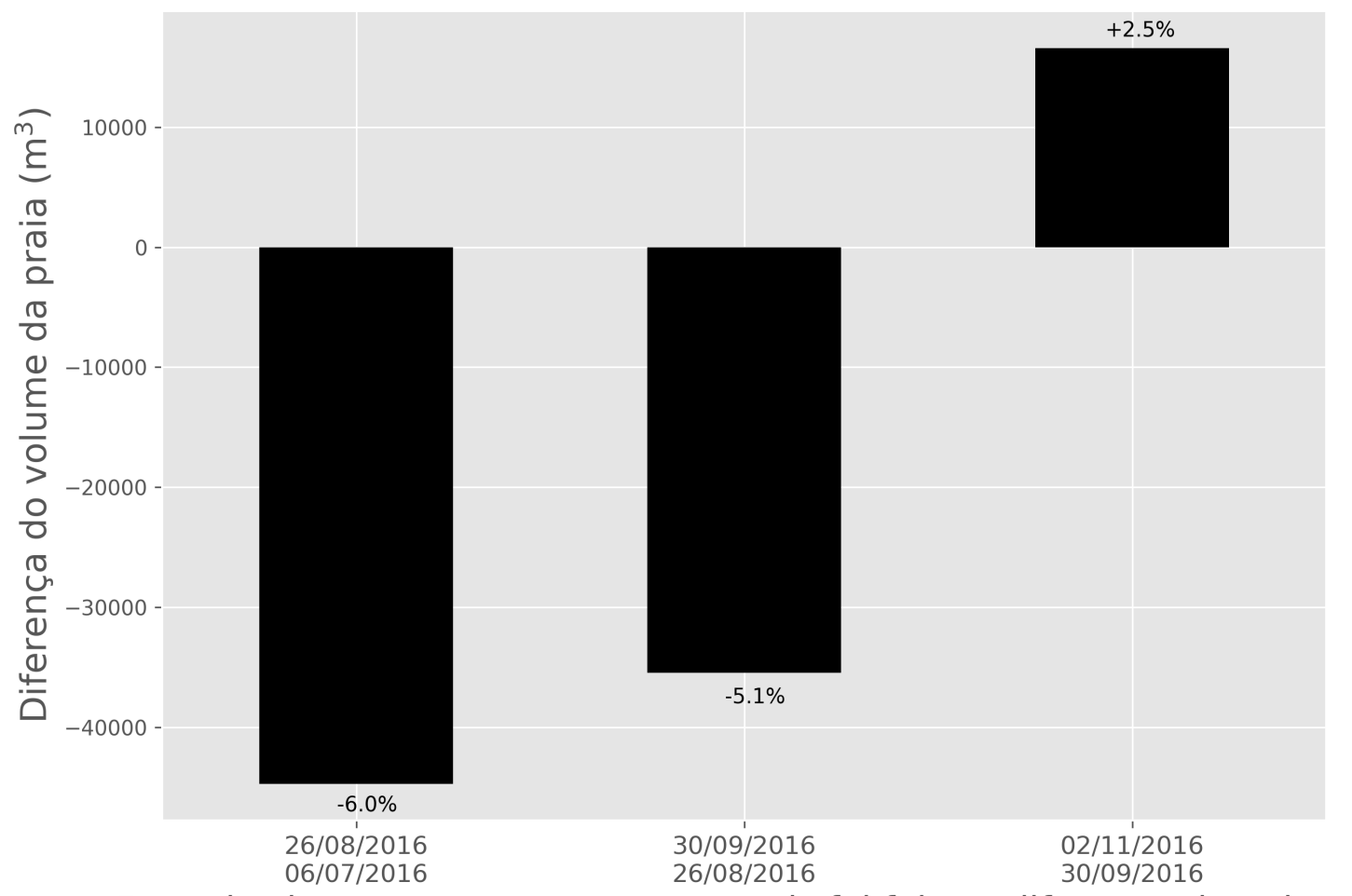

Data dos levantamentos entre os quais foi feita a diferença de volume

Figura 5.24: Diferença de volume entre os levantamento topográficos em Itararé, realizados no ano de 2016.

Para melhor visualização dos processos as praias foram dividas em setores como indicado nos Métodos (Item 5.2). Assim, como para as praias inteiras, foi estimado o volume dos setores em cada levantamento topográfico e a sua respectiva variação. Olhando separadamente Santos para 2015 e 2016, nota-se que a configuração da praia de maneira geral se manteve constante. Os 
setores que apresentam maior volume são o setor 1 e o setor 2, que se localizam mais próximo do Emissário Submarino, seguidos do setor 3 mais ao centro da praia. O menor volume foi visto no setor 4, diferente do esperado o setor 5 foi o penúltimo em uma escala decrescente, provavelmente devido a realimentação artificial da Ponta da Praia.

Em Santos durante 2015 (Figura 5.25) observa-se que os setores 1 e 2 apresentaram as menores variações de volume no período estudado. A diferença entre levantamento se intensifica a partir do setor 3, se mantendo mais intensas nos setores seguintes. Os setores 4 e 5 demonstraram mais sensibilidade aos processos, apresentando maiores perdas de volume e maior variação entre levantamentos. Comparativamente com a variação de volume da praia como um todo (Figura 5.26), nota-se que os setores apresentam variação de volume seguindo o mesmo padrão da praia como um todo toda, mas diferentes intensidades. A maior perda de volume da praia toda, foi observada entre 08/06/15-26/06/15 e 22/07/15-07/08/15, pois a perda de volume ocorreu em todos os setores, sendo maior a maior perda por setor vista entre 22/05/16 e 08/06/16 no setor 4 . Contudo, apesar da redução de volume a praia apresentou boa recuperação em todos os setores.

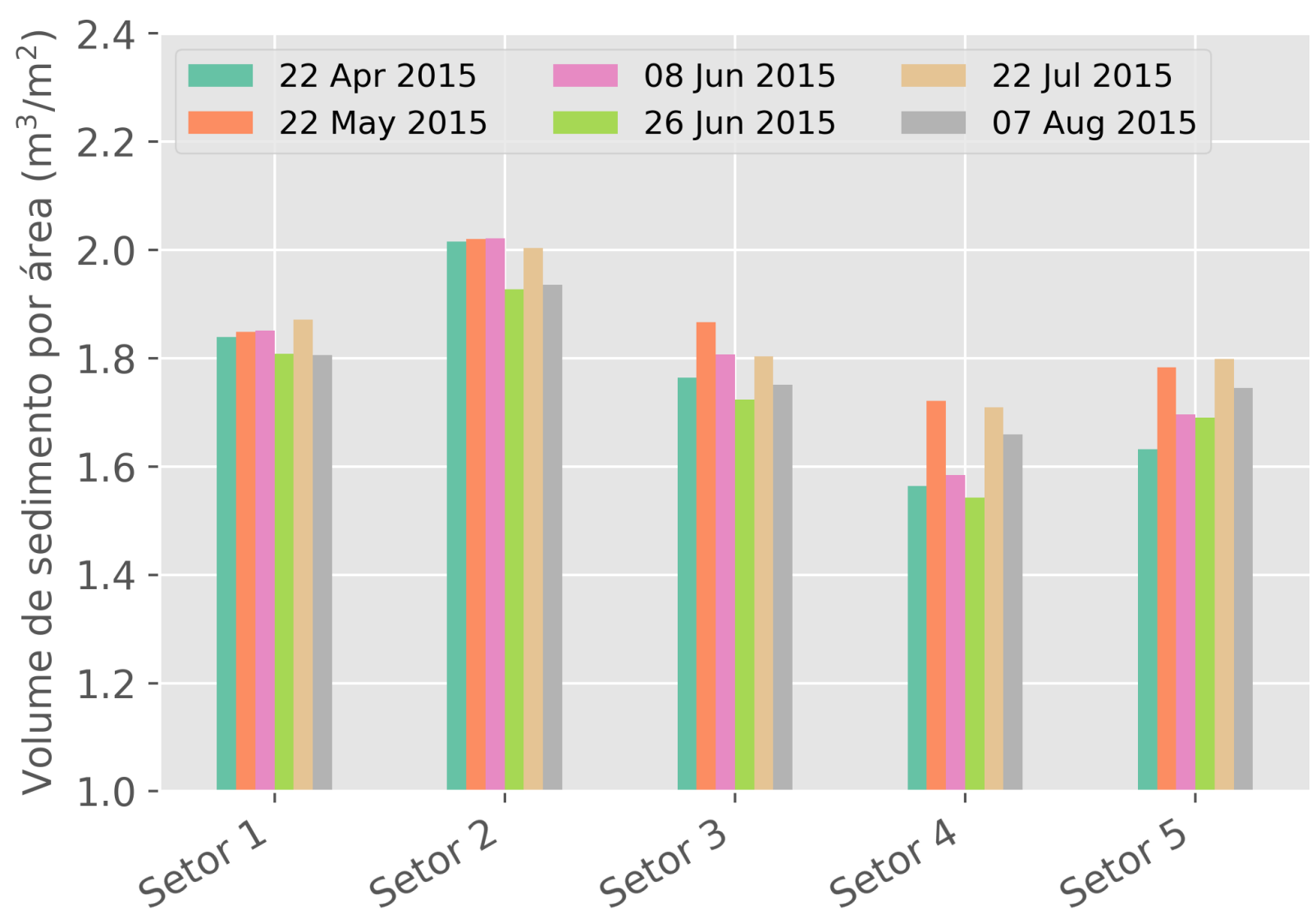

Figura 5.25: Gráfico do volume dos setores normalizado pela área de cada um $\left(\mathrm{m}^{3} / \mathrm{m}^{2}\right)$. As cores representam as datas dos levantamento topográficos de 2015 - Santos. 


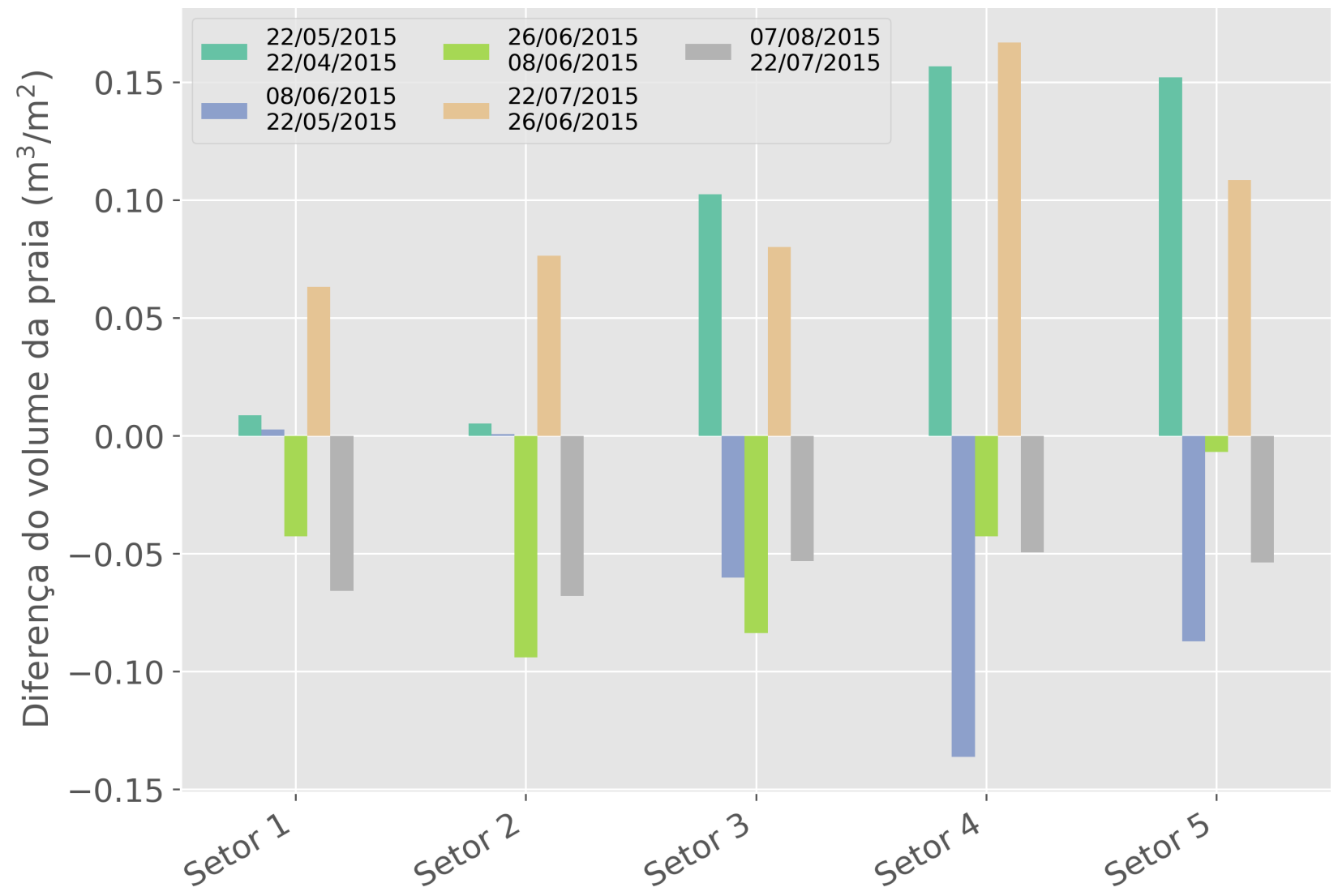

Figura 5.26: Gráfico da variação do volume normalizado dos setores em cada levantamento no ano de 2015 - Santos.

Os setores de Santos mostram comportamentos semelhantes em 2016 (Figura 5.27). Os setores 1 e 2 apresentaram as menores variações de volume, seguidos do setor 3, a partir de onde a variação passa a ser mais intensa e os setores 4 e 5 apresentaram uma maior variação volumétrica. Contudo as variações observadas entre setores em 2016 foram maiores que as de 2015 , com redução de volume de cerca de $-0.35 \mathrm{~m}^{3} / \mathrm{m}^{2}$ no setor 5 entre $06 / 07 / 16-26 / 08 / 16$ e aumento próximo a $0.25 \mathrm{~m}^{3} / \mathrm{m}^{2}$ no setor 4 entre 26/08/16-30/09/16 (Figura 5.28). O setor 4 foi o que apresentou maior redução de volume ao longo de 2016, apesar da maior redução pontual ter sido observada no setor 5 . Ao final do período estudado em 2016, todos os setores apresentaram volume menor do que tinham no início dos levantamentos topográficos deste ano. Mostrando que a praia de Santos como um todo perdeu sedimento, condizendo com o esperado para o período estudado no qual ocorre com mais frequencia a entra de eventos energéticos. Essa tendência provavelmente não seria observada caso os levantamentos topográficos fosse realizados periodicamente ao longo do ano todo, pois incluiria os meses mais calmos nos quais a praia consegue recuperar o sedimento perdido. 


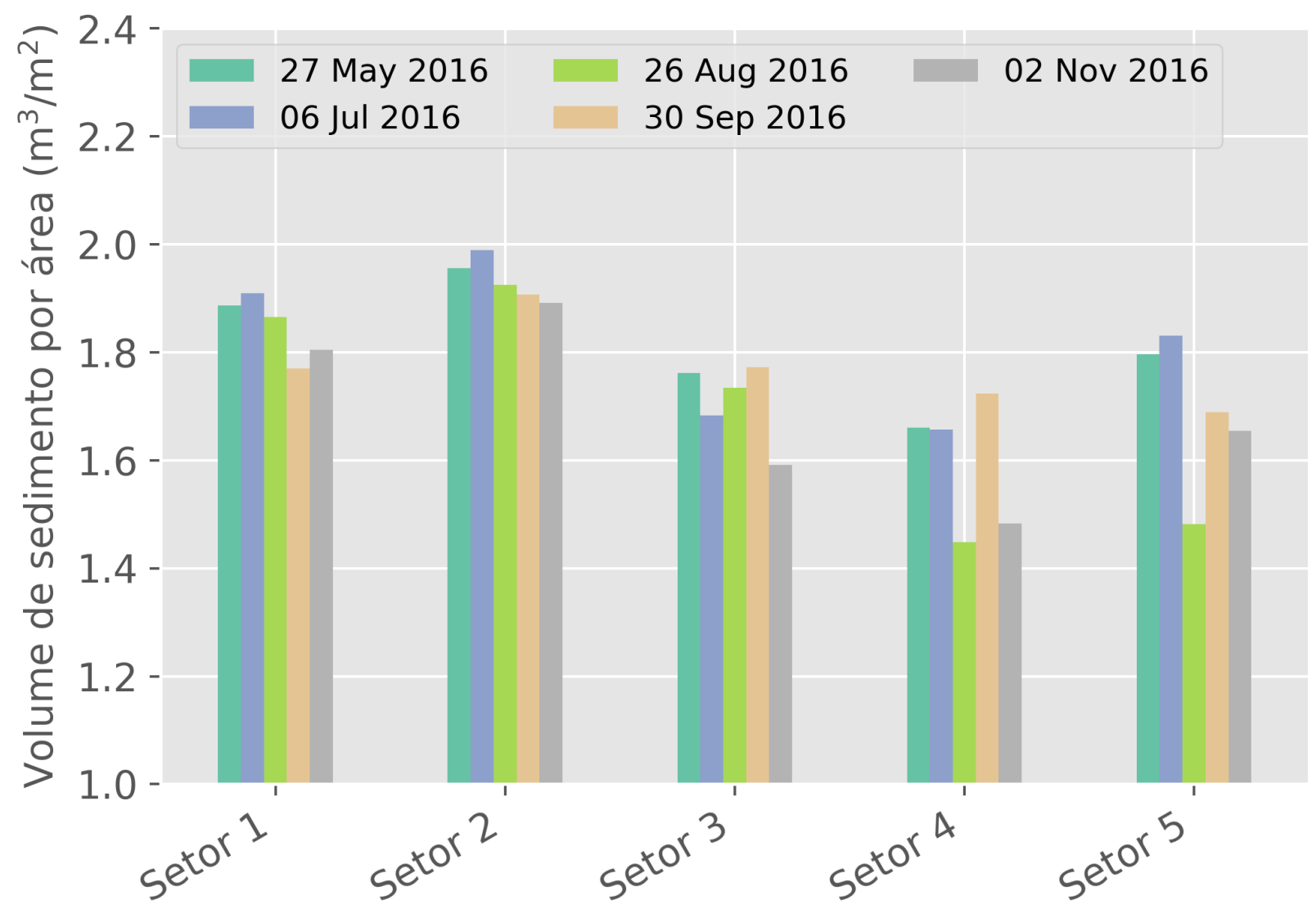

Figura 5.27: Idem a Figura 5.25, mas para o ano de 2016 - Santos.

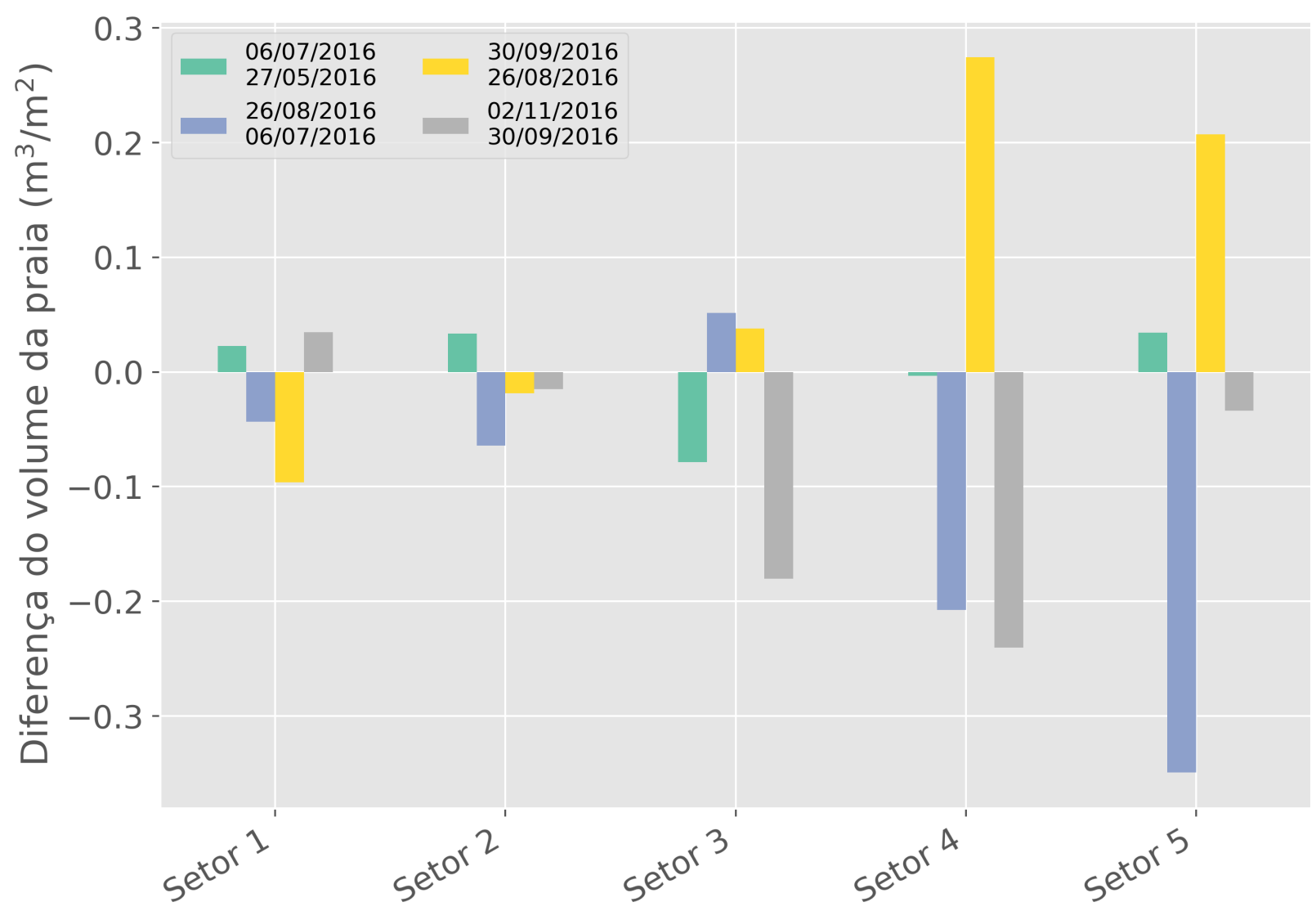

Figura 5.28: Idem a Figura 5.26, mas para o ano de 2016 - Santos. 
Para melhor visualização dos processos, assim como em Santos, Itararé foi dividia em 3 setores como indicado nos Métodos. O volume dos setores em cada levantamento topográfico e a sua respectiva variação foram calculados e estão indicados nas Figuras 5.29 e 5.30. Observase que diferente de Santos os setores de Itararé apresentam volumes mais semelhante, indicando uma praia mais homogênea. O padrão de variação de volume apresentado pela praia toda, foi encontrado apenas no setor 3 , enquanto os outros setores mostraram ganhos e perdas diferentes. As maiores mudanças no volume foram apresentadas pelo setor 3 , que se encontra na zona de sombra da Ilha Urubuqueçaba. Este também foi o setor que apresentou um dos maiores volumes $\left(1.6 \mathrm{~m}^{3} / \mathrm{m}^{2}\right)$ em 06/07/16 e um dos menores, $1.3 \mathrm{~m}^{3} / \mathrm{m}^{2}$ em 30/09/16. Já o setor 2 foi o que apresentou as menores diferenças volumétricas entre levantamentos, chegando a não apresentar variação significativa entre o segundo e o terceiro levantamento, indicando que a região central da praia de Itararé é a mais estável

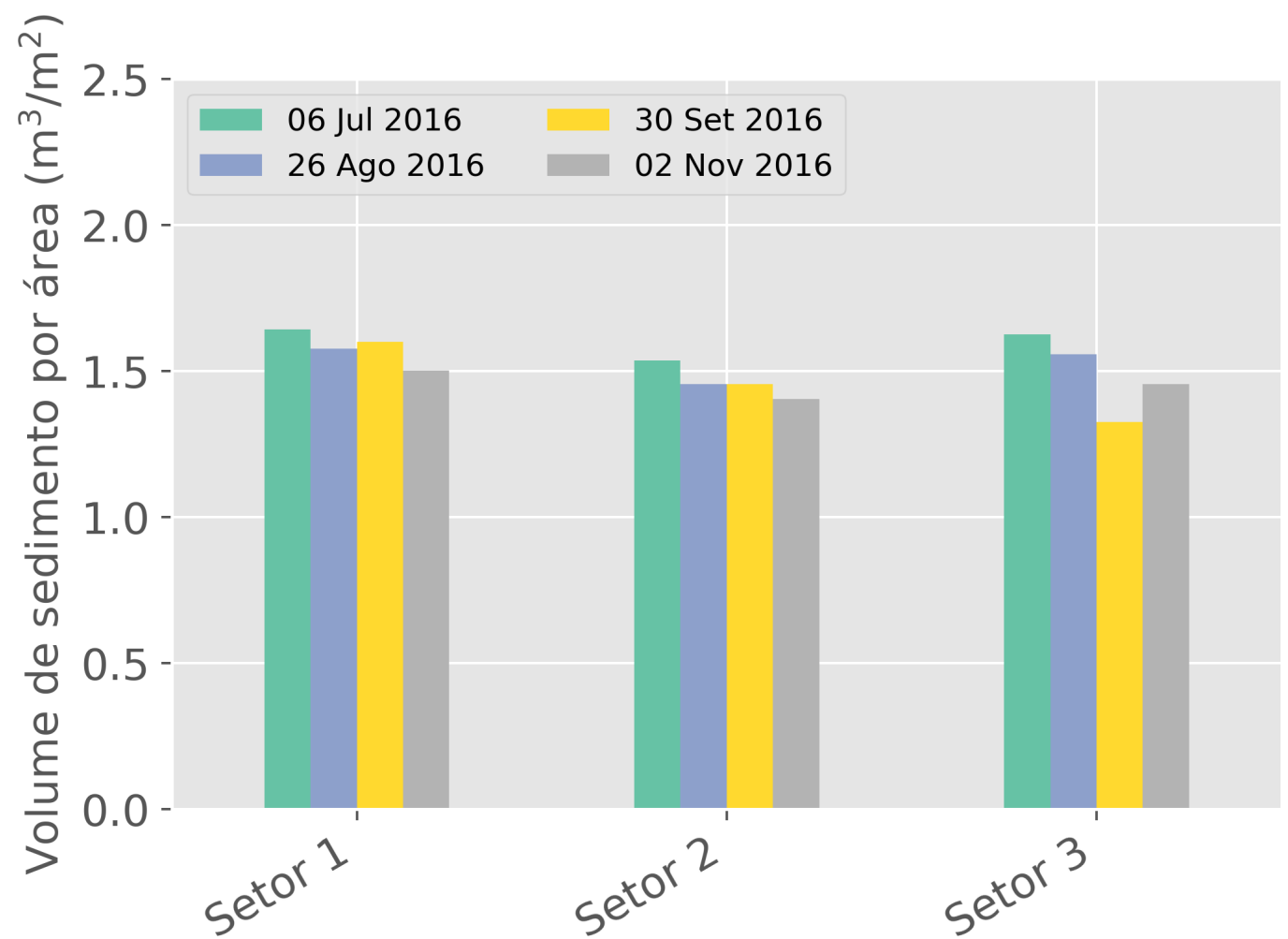

Figura 5.29: Gráfico do volume dos setores normalizado pela área de cada um dos levantamentos em Itararé $\left(\mathrm{m}^{3} / \mathrm{m}^{2}\right)$. As cores representam as datas dos levantamento topográficos em Itararé. 


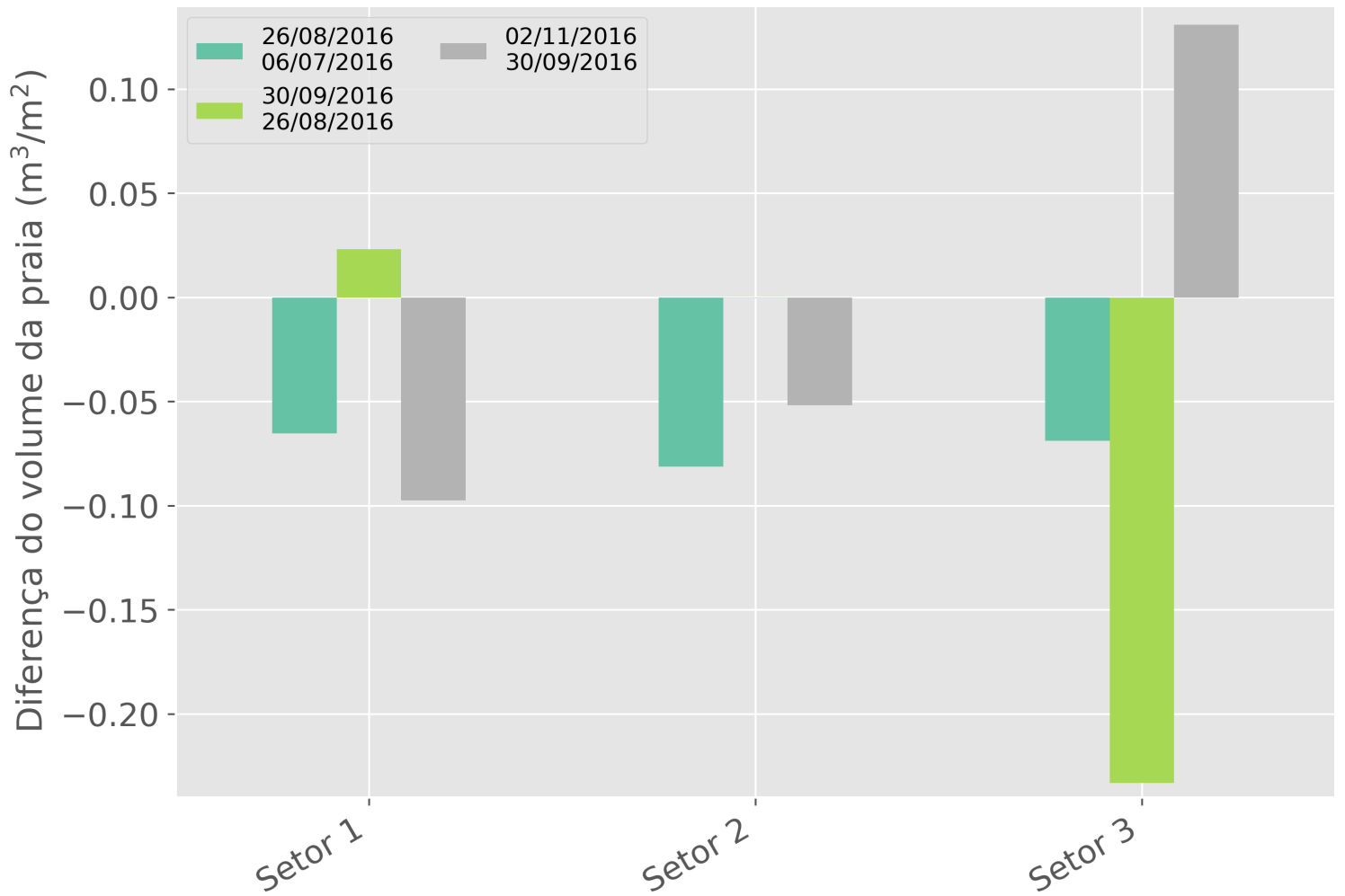

Figura 5.30: Gráfico da variação do volume normalizado dos setores em cada um dos levantamentos em Itararé.

O perfil extraído dos MDTs de Santos para cada setor ajuda a visualizar as mudanças encontradas entre os levantamentos topográficos. A Figura 5.31 confirma que os perfis mais próximos ao Emissário Submarino têm extensão praial maior que o restante da praia, e que esta extensão passa a ser menor a partir do setor 3. O setor 5 apresenta extensão maior que o setor 4, provavelmente devido a posição que foi retirado o perfil e devido a engorda artificial que ocorre na Ponta da Praia.

É possível observar que os setores 3,4 e 5 apresentaram maior variação nos volumes, são os que possuem maior declividade média dos perfis de $0.80^{\circ}, 0.85^{\circ}$ e $0.85^{\circ}$ respectivamente, o que indica que estes setores têm mais tendência intermediária que o restante da praia. Os setores 1 e 2 que se mostraram mais estáveis tem declividade levemente menor em torno de $0.63^{\circ}$ e $0.45^{\circ}$ respectivamente. 


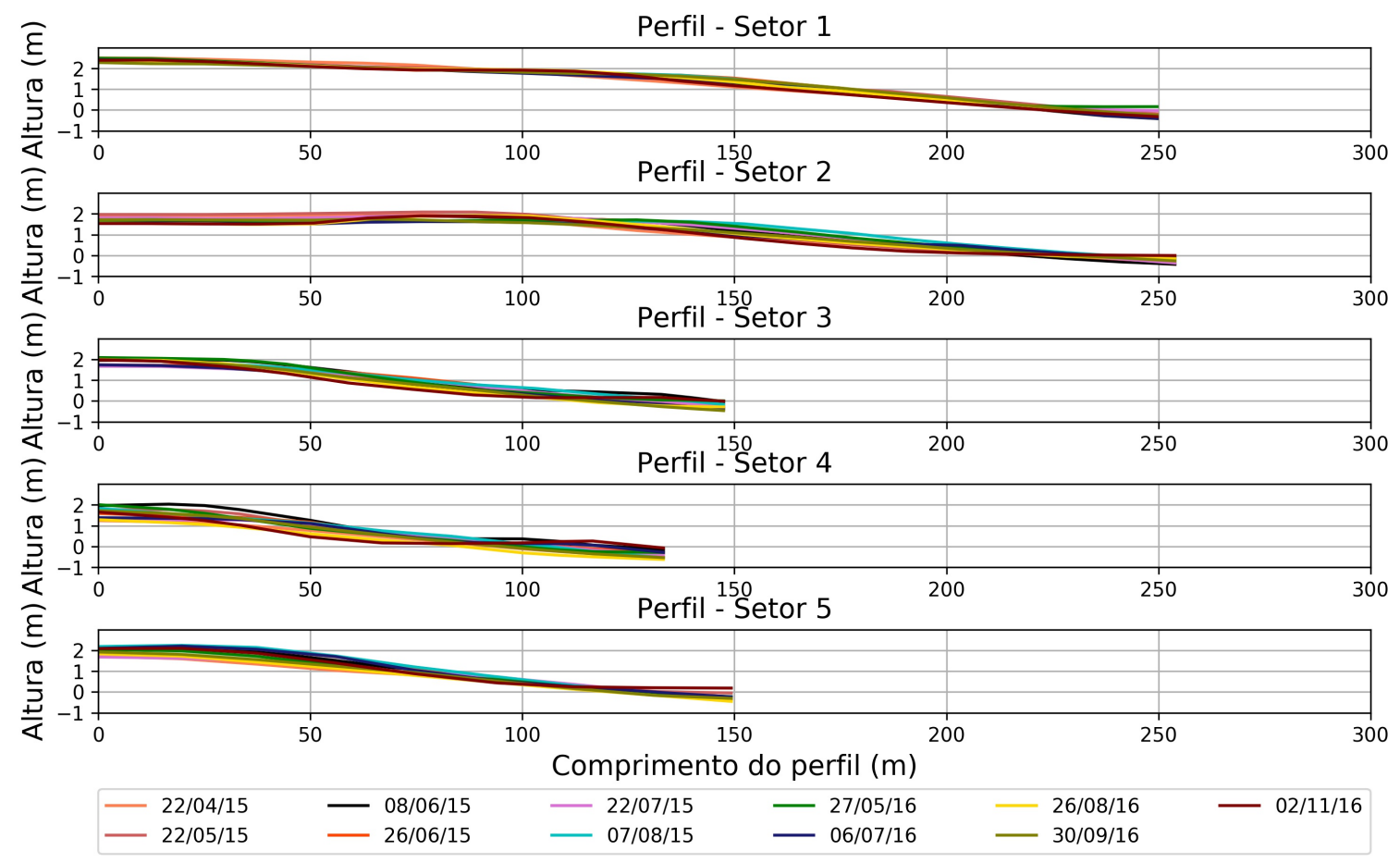

Figura 5.31: Perfis praias dos levantamentos topográficos para cada setor de Santos.

Em Itararé também foram extraídos perfis topográficos (Figuras 5.32). No setor 3 são apresentados dois perfis, um em cima do tombolo da zona de sombra e outra na lateral oeste do tombolo. Como esperado a largura da praia nos setores 1 e 2 é bem semelhante e a praia se torna mais espessa no setor 3 , onde temos a zona de sombra, sendo maior na região do tombolo. As variações entre os levantamentos aparecem ao longo de toda largura dos perfis em todos os setores, menos no Perfil 3.1 que se encontra acima do tombolo. Este perfil se mostra mais estável devido a proteção da Ilha. Diferente de Santos, o setor 3 de Itararé é o que apresenta maior variação nos volumes e é também aquele que possui menor declividade do perfil: $0.74^{\circ}$ para o Perfil $3.1 ; 0.82^{\circ}$ para o Perfil 3.2. 

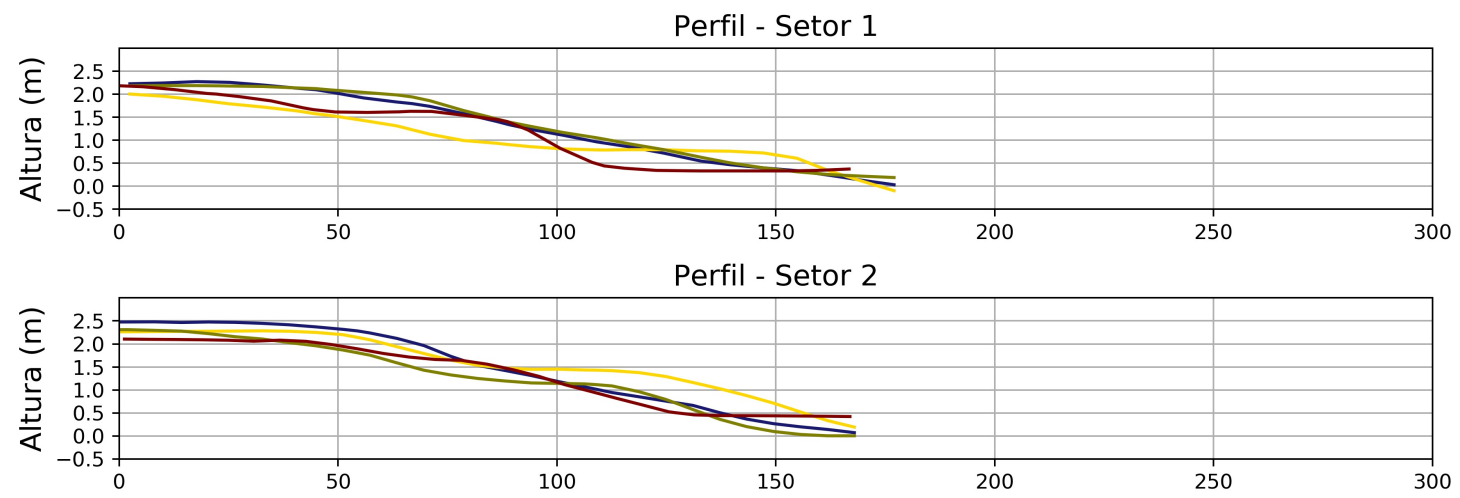

Perfil 3.1 - Setor 3

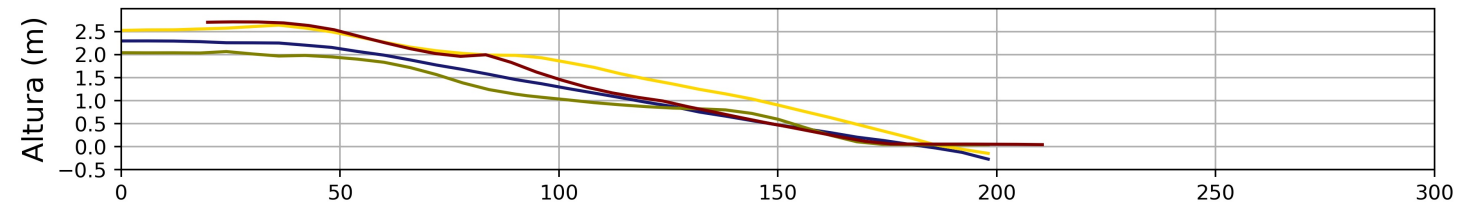

Perfil 3.2 - Setor 3

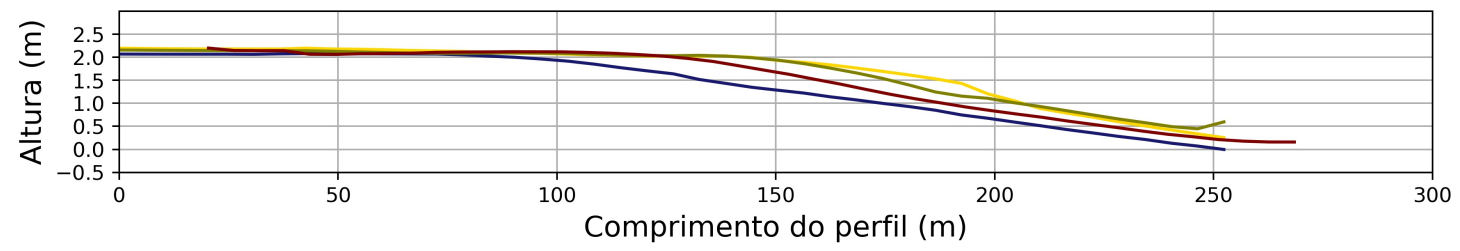

- 06/07/16 - 26/08/16 - 30/09/16 - 02/11/16

Figura 5.32: Perfil praial dos levantamentos topográficos para cada setor de Itararé. No setor 3 temos 2 perfis, indicando as diferenças topográficas na zona de sombra da Ilha Urubuqueçaba.

\subsection{Discussão}

A Baixada Santista apresenta praias com diferentes características e diferentes respostas aos processos atuantes. As praias de Santos e Itararé, são as maiores da baixada e estão ambas expostas a ação das ondas de sul e sudeste, porém apresentam diferenças batimétricas e características geológicas. Itararé está protegida por duas ilhas, Urubuqueçaba e Porchat, enquanto Santos está toda exposta as ondas e sofre com alterações batimétricas geradas pela dragagem do canal do porto.

Os resultados obtidos neste capítulo permitem avaliar o comportamento morfodinâmico do sistema praial de Santos e Itararé, para o período de dois anos de estudo. Os vários processos atuantes em uma praia causam o transporte do sedimento disponível de setor para o outro, resultando em mudanças morfológicas (Siegle e Asp 2007). Este material pode ser redistribuído tanto ao longo como através da praia, dependendo do processo dominante. Os processos envolvidos no controle deposicional e erosivo das praias sofre a ação dos eventos energéticos, que podem intensificar a atuação desses processos principalmente relacionados a transformação de ondas na zona costeira (Regnauld et al. 2004).

Com base nos resultados apresentados, é possível identificar em ambas as praias, trechos 
mais suscetíveis a ação desses processos modeladores da praia e trechos mais estáveis, que sofrem menos com a ação dos processos. Pode-se relacionar os resultados obtidos da topografia e os cálculos da deriva potencial e força de onda, identificando a influência dos processos na variação morfológica das praias.

Os experimento numéricos permitiram compreender com mais detalhe a ação das ondas na zona praial. A força de onda se distribui no arco praial, se mostrando mais intensa na porção oeste, em toda praia de Itararé e nos setores 1 e 2 de Santos, e perde intensidade para leste. Em Itararé, a força de onda se mostra mais homogênea ao longo da praia, sendo mais intensa no centro, mas com valores altos também nos extremos leste e oeste. Em Santos a força de onda é mais intensa na porção oeste e diminui para leste, contudo há um pico de energia no setor 5.

Observa-se, assim como esperado, que as ondas de quadrante sul chegam com maior intensidade nas praias e consequentemente geram uma deriva potencial mais forte, sendo estas mais capazes de remobilizar o sedimento (Magini, Harari, e Abessa 2007). De modo geral, ao longo do período estudado ambas as praias apresentaram perda de volume, o que era esperado uma vez que o estudo foi realizado na época de maior ocorrência de eventos energéticos.

Entre os levantamentos, observa-se uma relação entre a força de onda, a deriva potencial e a variação do volume de ambas as praias. Em 2015, no geral se observou um maior volume total de sedimento na praia Santos do que em 2016. Neste ano a força de onda foi menos intensa e o mesmo ocorre com a magnitude da deriva potencial. Portanto, devido a menor entrada de ondas de sul mais intensas, geralmente associadas a passagem de frentes frias, a redução do volume sedimentar é menor e a recuperação da praia se torna mais fácil, como visto em 2015.

O ano de 2016 contou com mais passagem de eventos energéticos, como observado nas estimativas de força de onda, que apresentam resultados mais intensos, assim como o transporte potencial. Neste ano os levantamentos topográficos apresentaram menor volume de sedimento, e mesmo nos períodos entre levantamentos com força de onda menor a praia apresentou pouca recuperação de volume em ambas as praias estudas. Pode-se concluir que o arco praial da baía de Santos, quando afetada por eventos energéticos seguidos não é capaz de se recuperar totalmente da perda de sedimento, tornando necessário que a praia passe por um período de dias com baixa energia de onda chegando para que ela comece a se recuperar.

Em agosto de 2016, ocorreu uma grande ressaca em Santos que afetou as duas praias no dia 21 (G1-globo, 21/08/16: http://g1.globo.com/sp/Santos-regiao/noticia/2016/ 08/ressaca-inunda-avenida-da-praia-em-Santos-e-causa-bloqueios-no-canal-6. html). Esse evento pode ser observado nos resultados de onda e volume praial, nesse período foi estimado força de onda maior que refletiu no levantamento realizado no dia 26/08/16. Este levantamento apresentou a maior perda de volume vista em ambas as praias, $-4.2 \%$ em Santos e $-6 \%$ em Itararé.

Os setores usados para analisar as praias nos permitiram observar os diferentes comportamentos de cada trecho. O setor 3 de Itararé apresentou maior variação de volume de sedimento, enquanto os outros dois se mostraram mais estáveis, apesar da alta força de onda que chega 
nesta praia.

Itararé apresenta perfil praial extenso e com pouca declivada, nota-se que todos os setores possuem características dissipativas, portanto mais resistentes a ação de frente fria. Apesar da praia ter resultado negativo de volume no período estudado, não foi reconhecido nenhum trecho erosivo. Farinnaccio, Goya, e Tessler (2009) afirma que após a fixação do tombolo na Ilha Porchat (na década de 1950), Itararé vem sofrendo acresção de sedimento, pois o tombolo bloqueou o transporte para oeste, gerando acumulo nessa porção da praia e confirmando o volume que foi obtido no setor 1, ligeiramente maior que nos outros setores e mais estável. Contudo, foi observado que o setor 3 é o mais sensível a variações no clima de onda, consequentemente o mais vulnerável a eventos energéticos.

A deriva potencial também fornece informações sobre o comportamento de cada setor. Os pontos mais extremos tem intensidade maior e se direcionam para o centro da praia, convergindo. Sabe-se, também, que os setores 2 e 5 tem maior transporte que os 1 e 6 gerando uma divergência residual em ambas as pontas da praia. Contudo, nenhuma dessas informações justifica o fato da maior variação de volume ser no setor 3, o que pode estar relacionado ao fato de ser uma região de menor energia que eventualmente recebe maior energia.

Na praia de Santos os setores 1 e 2, apresentaram maior volume de sedimento com menor variação, apesar de também receberem força de onda maior que os outros setores, demostrando uma continuidade da Itararé para Santos apesar das divisões naturais e humanas. Esses dois setores apresentaram a faixa de areia extensa e menor declividade que os outros, assim como os resultados apresentados em Elliff et al. (2013) e Farinnaccio, Goya, e Tessler (2009) mostram que a parcela da praia localizada entre os canais 2 e 3 é composta por areia fina, baixa inclinação e características dissipativas. Portanto, essas características mais dissipativas podem ser responsáveis pela resistência destes trechos a ação das ondas. Espera-se também um acúmulo de sedimento na porção mais noroeste da praia, devido a direção predominante da deriva potencial para esse lado. No setor 2 pode-se observar convergência e divergência da deriva, pontos 4 , 5, 6 e 7; no setor 1 ocorre divergência entre os pontos 2 e 3, mas a convergência aparece entre os pontos 1 e 2 , e 3 e 4 , o que pode justificar a maior estabilidade deste setor.

Os setores 3, 4 e 5 de Santos recebem força de onda menor do que os outros setores, estes também correspondem a porção da praia que apresente faixa de areia mais estreita e com menor volume de sedimento. Apesar da baixa força de onda atingindo estes 3 setores, foi observado que a maior variação de volume ocorre exatamente nestes trechos, mostrando que a praia é mais sensível à ação das ondas nos setores 3, 4 e 5, que provavelmente se deve a maior declividade do perfil praial e a pequena faixa de areia, o que indica que esses trechos têm tendências intermediárias. Essa sensibilidade é maior no setor 4, seguido do setor 5, estes foram os setores que mais sofreram com a entrada da frente fria de Agosto de 2016 que causou inundação da avenida e garagem de prédios deixando a praia submersa neste trecho. Praias intermediárias e refletivas sofrem mais com a influência de eventos extremos e são mais suscetíveis a erosão (Shih e Komar 1994; Komar 1998), isso é observado nos setores 4 e principalmente 5. Adicionalmente, 
o setor 4 apresenta divergência residual no transporte da deriva potencial, representado pelos pontos de deriva, 10 e 11. A deriva potencial não é significativa no setor 5, não nos permitindo concluir nada sobre sua ação neste trecho e, no setor 3, observa-se convergência residual no ponto 9 e divergência no ponto 8 , provavelmente por este motivo a variação de volume já se mostra menos intensa neste setor.

O setor 5, corresponde a Ponta da Praia, uma região de interesse devido intensa erosão. Esta região apresenta uma faixa de areia reduzida que constantemente passa por processos de realimentação artificial realizados pela prefeitura. Adicionalmente, o perfil deste trecho possui maior inclinação quando comparado ao restante da praia. Neste trabalho, foi possível mostrar que quando ocorre a entrada de uma frente fria, neste setor o pico de força de onda se torna mais intenso que nos setores próximos, como o 3 e 4, apesar de o setor 5 e 4 apresentarem características semelhantes. Acredita-se que esse pico de onda seja responsável pela grande perda de volume que foi vista neste setor, isso pode ser observado no levantamento de agosto de 2016, que foi realizado após a entrada da uma forte frente fria. Na série temporal de força de onda (Figuras 5.15 e 5.16) foi observado um grande pico de energia próximo dessa data, comprovando a sensibilidade deste setor aos eventos energéticos. O estudo de Italiani (2014) acompanhou a introdução artificial de sedimentos na Ponta da Praia através de levantamentos topográficos sequenciais entre 2013 e 2014. A comparação entre os resultados mostra que a tendência erosiva continua nesse trecho da praia, com erosão gradual e redução de volume principalmente durante eventos de tempestade.

Farinnaccio, Goya, e Tessler (2009) sugerem que, após a instalação do Emissário José Menino, o Ponta da Praia começou a sofrer um recuo do litoral, sugerindo que a causa do recuo é a falta de suprimento de sedimentos que se acredita ser mantido no afluente. No entanto, os resultados da deriva potencial aqui apresentados não mostram transporte potencial em Itararé no sentido do emissário/praia de Santos e, o transporte potencial de Santos é predominantemente sentido emissário. Portanto, o emissário não influenciaria no aporte de sedimento para Santos. Adicionalmente, também foi observado neste trabalho que a Ponta da Praia é atingida com maior energia de onda na ocorrência de eventos extremos do que normalmente é apresentado em bom tempo. Essa maior energia de onda na Ponta da Praia pode estar associada a profundidade do canal do porto, o que permite que a onda chegue na praia sem ser influenciada pelo fundo do mar, assim com maior energia, sendo responsável pela perda de sedimento e o recuo da Ponta da Praia. Cassiano, Ribeiro, e Yassuda (2012) apresenta resultados que condizem com os nossos, indicando que no meio da praia o padrão de ondas é menor em comparação com a parte leste, Ponta da Praia. Em seu trabalho Cassiano, Ribeiro, e Yassuda (2012) também comprova que padrão é intensificado após o aprofundamento do canal.

Adicionalmente, a diferença de elevação entre o primeiro e o último levantamento de campo indica que em geral há erosão ao longo da praia, com o extremo leste da praia sofrendo o maior variações e perda de sedimentos. Esse comportamento é esperado para o período amostrado, que abrangeu as condições mais enérgicas para a área. Também enfatiza que o trecho da praia 
próximo ao canal do porto (setores 4 e 5) é mais vulnerável à passagem de frentes frias e é submetido a maior erosão do que o resto da praia.

De acordo com o estudo de Magini, Harari, e Abessa (2007) a atual fisiografia da baía de Santos com o píer do emissário submarino, em somatório com os a zona de sombra da Ilha Urubuqueçaba, contribuem para dividir duas áreas que sofrem o mesmo processo de sedimentação as praias de Santos e a praia de Itararé, como é também obeservado neste trabalho a área entre os canais 2 e 3 de Santos e a porção leste de Itararé são mais propensos à acresção de sedimento.

Com isso, foi observado que a praia de Santos apresenta maior sensibilidade à ação de eventos extremos, principalmente na porção leste, devido sua proximidade ao canal do porto que altera a transformação das ondas e permite que ela chegue na praia com menor força e capacidade de remodelar o sedimento. Somado a isso, a porção leste de Santos apresenta características intermediárias, agravando a ação das ondas, causando erosão. Itararé, por ser mais protegida tem maior extensão na faixa de areia e menor declivada, sendo mais resistente as frentes frias e não apresentando erosão. 


\section{Eventos de Sobrelavagem}

\subsection{Introdução}

A sobrelavagem costeira é um fenômeno importante na dinâmica e evolução do litoral e que sofrem alterações quando há a presença de obras costeiras. O conhecimento dos níveis de

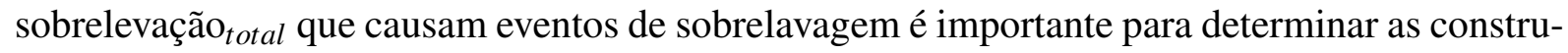
ções de obras de proteção costeira, de modo que elas sejam construídas com elevação suficiente para minimizar a sobrelavagem (Pullen et al. 2007; Linham e Nicholls 2010; Mase et al. 2013).

Assim, o objetivo desse capítulo é avaliar cenários de onda combinados com nível do mar em diferentes condições de maré meteorológica associadas a maré de quadratura e sizígia com o intuito de determinar os cenários que causam sobrelavagem em Santos e Itararé e quais setores da praia estão mais vulneráveis. A seguir são apresentados os métodos utilizados no cálculo do

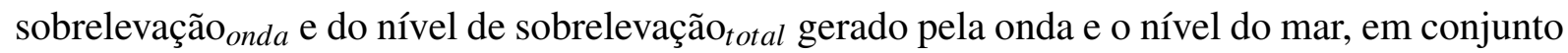
com os resultados obtidos para cada cenário em cada setor de ambas as praias e a discussão desses resultados.

\subsection{Métodos}

Para o presente estudo, foram combinados cenários de onda, que nos permitiram calcular o sobrelevação ${ }_{\text {onda }}$, com cenários de maré meteorológica. Estes cenários foram associados a maré de quadratura e sizígia para o cálculo do nível de sobrelevação total $_{\text {gerado nas determinadas }}$ condições de onda e nível do mar. Os cenários foram aplicados para os 3 setores de Itararé e os 5 setores de Santos.

\subsubsection{Sobrelevação ${ }_{\text {ond }}$}

O cálculo do sobrelevação ${ }_{\text {onda }}$ foi realizado usando a formulação proposta por Mase et al. (2013). Para meio de comparação foi calculado a sobrelevação ${ }_{\text {onda }}$ máximo da onda, a sobrelevação ${ }_{\text {onda }}$ de $99 \%, 37 \%$ e de $2 \%$, nas quais as porcentagem indicam a quantidade de ondas, considerando um trem de ondas, que pode atingir a praia com o valor de sobrelevação ${ }_{\text {onda }}$ calulado:

$$
\begin{gathered}
R_{99 \%}=1.54 H_{0}(2.99-2.73 \exp (-0.57 \xi) \\
R_{37 \%}=1.09 H_{0}(2.99-2.73 \exp (-0.57 \xi) \\
R_{2 \%}=H_{0}(2.99-2.73 \exp (-0.57 \xi)
\end{gathered}
$$

Onde $H_{0}$ é a altura de offshore, e $\xi$ é o número de Irribaren calculado da seguinte forma: 


$$
\xi=\frac{\tan \beta}{\sqrt{\left(H_{0} / L_{0}\right)}}
$$

Onde $\beta$ é a declividade da praia e $L_{0}$ é o comprimento de onda em água profunda $\left(L_{0}=\right.$ $g T_{0}^{2} / 2 \pi, g=9.8 \mathrm{~m} / \mathrm{s}^{2}$ aceleração da gravidade, $T_{0}$ período de onda em água profunda). A porcentagem indica que $99 \%, 37 \%$ e $2 \%$, respectivamente, das ondas observadas vão atingir ou exceder o valor calculado do sobrelevação ${ }_{\text {onda }}$.

Entre as muitas fórmulas disponíveis (Mase 1989; Nielsen e Hanslow 1991; Van der Meer e Stam 1992; Stockdon et al. 2006; Pullen et al. 2007), essa foi escolhida pois foi desenvolvida para muros construídos em terra ou em águas muito rasas, características que se aproximam da área de estudo deste trabalho. O período de onda de águas profundas e a altura de onda não refratada foram utilizados como dado de entrada. O número Irribaren foi calculado a partir da declividade da praia como descrito acima.

Para a aplicação da formulação acima, foi coletada a altura do muro do calçadão de Santos em 6 pontos escolhidos ao longo da praia de Santos com o uso do DGPS, em Itararé não foi possível fazer a coleta desses dados, portanto foi utilizado uma média dos valores encontrados em Santos, uma vez que o muro é contínuo ao longo da praia. A atura do muro usada é referente ao nível zero do mar. A partir desses pontos foram usado os dados topográficos coletados em ambas as praias para calcular o perfil hipotético da praia nos pontos em que há dados do calçadão para cada data de levantamento de campo, permitindo obter o seu valor médio. Esse valor médio de perfil hipotético foi usado para calcular o número de Irribaren.

Os valores de altura de onda e período de pico, foram extraídos da série temporal de 10 anos do modelo WaveWatch III da NOAA. Através da análise estatistica desses dados, foram obtidas as alturas de onda mais frequentes e o período de pico associado. Através dessa estatística foram selecionados cenários de onda para aplicar na formulação. Os cenários estão representados na Tabela 2.

Tabela 2: Cenários de Hs e Tp usados para calcular o sobrelevação ${ }_{\text {onda }}$. Onde tem o ponto, indica que o Hs está associado aquele Tp.

\begin{tabular}{|c|l|l|l|l|l|l|l|l|l|l|l|}
\hline $\mathrm{Tp} \backslash \mathrm{Hs}$ & $1.0 \mathrm{~m}$ & $1.5 \mathrm{~m}$ & $2.0 \mathrm{~m}$ & $2.5 \mathrm{~m}$ & $3.0 \mathrm{~m}$ & $3.5 \mathrm{~m}$ & $4.0 \mathrm{~m}$ & $4.5 \mathrm{~m}$ & $4.5 \mathrm{~m}$ & $4.8 \mathrm{~m}$ & $5.0 \mathrm{~m}$ \\
\hline $8 \mathrm{~s}$ & & & & & & & & & & & \\
\hline $9 \mathrm{~s}$ & & & & & & & & & & & \\
\hline $10 \mathrm{~s}$ & & & & & & & & & & & \\
\hline $13 \mathrm{~s}$ & & & & & & & & & & & \\
\hline
\end{tabular}

Nestes cenários foram incluídos duas combinações extremas de Hs e Tp observados nos dados do WW3, a onda de $4.5 \mathrm{~m}$ e $13 \mathrm{~s}$ de pico e a de $4.8 \mathrm{~m} \mathrm{e} 8 \mathrm{~s}$ de pico. O último cenário 
correspondente a ondas de $5.0 \mathrm{~m}$ e $8 \mathrm{~s}$ de pico é hipotético, buscando representar uma condição extrema para a região.

\subsubsection{Sobrelavagem}

A avaliação da sobrelavagem extrema foi realizada usando como base os métodos apresentados no trabalho de Silveira et al. (2016). Os processos de extrema sobrelavagem corresponde a valores extremos de sobrelevação ${ }_{\text {onda }}$, e/ou valores extremos de maré meteorológica associados à maré astronômica.

Portanto, foram criados cenários de maré meteorológica através de uma série temporal (1993-2008) de nível do mar do Terminal de Fertilizantes de Conceiçãozinha do porto de Santos (CODESP). Desses dados foi extraído a maré meteorológica e realizada uma estatística sobre ela. Os valores mais frequentes estão entre $0.0 \mathrm{~m}, 0.5 \mathrm{~m}$ e $0.75 \mathrm{~m}$, e observa-se valores mais extremos de $1.0 \mathrm{~m}$ e $1.2 \mathrm{~m}$ de maré.

Os cenários foram fechados em valores de: $0.0 \mathrm{~m}, 0.5 \mathrm{~m}, 0.75 \mathrm{~m}, 1.0 \mathrm{~m}$ e $1.2 \mathrm{~m}$. Para obter o nível do mar soma-se os valores de maré astronômica, foram incluídos nesses cenários mais duas possibilidades, maré de sizígia e maré de quadratura. Pelos dados de nível do mar, obteve-se o valor de $0.9 \mathrm{~m}$ para sizígia e $0.009 \mathrm{~m}$ para a quadratura.

A sobrelavagem é a soma do sobrelevação ${ }_{\text {onda }}$ com o nível do mar, assim calcula-se um valor de sobrelevação total $_{\text {do sobrelevação }}$ onda. Assim, os cenários de sobrelevação ${ }_{\text {onda }}$ foram associados com os cenários de nível do mar para obter a altura que água do mar somada a onda (sobrelevação) atingiria a costa, e sendo posteriormente comparados com os valores de altura do calçadão.

$$
\begin{aligned}
& \text { sobrelevação }_{\text {total }}=\text { nível do mar }+ \text { sobrelevação }_{\text {onda }} \\
& \text { sobrelevação } \text { total }>\text { Calçadão } \rightarrow \text { Sobrelavagem extrema } \\
& \text { sobrelevação } \text { total }_{\text {l }}<\text { Calçadão } \rightarrow \text { Não ha sobrelavagem }
\end{aligned}
$$

Estes cálculos foram realizados para os perfis extraídos dos mesmos setores utilizados no Item 5 deste trabalho. Os perfis foram extraídos em pontos onde a altura do muro era conhecida e foram usados para representar os seus rescpetivos setores Figura 6.1. 


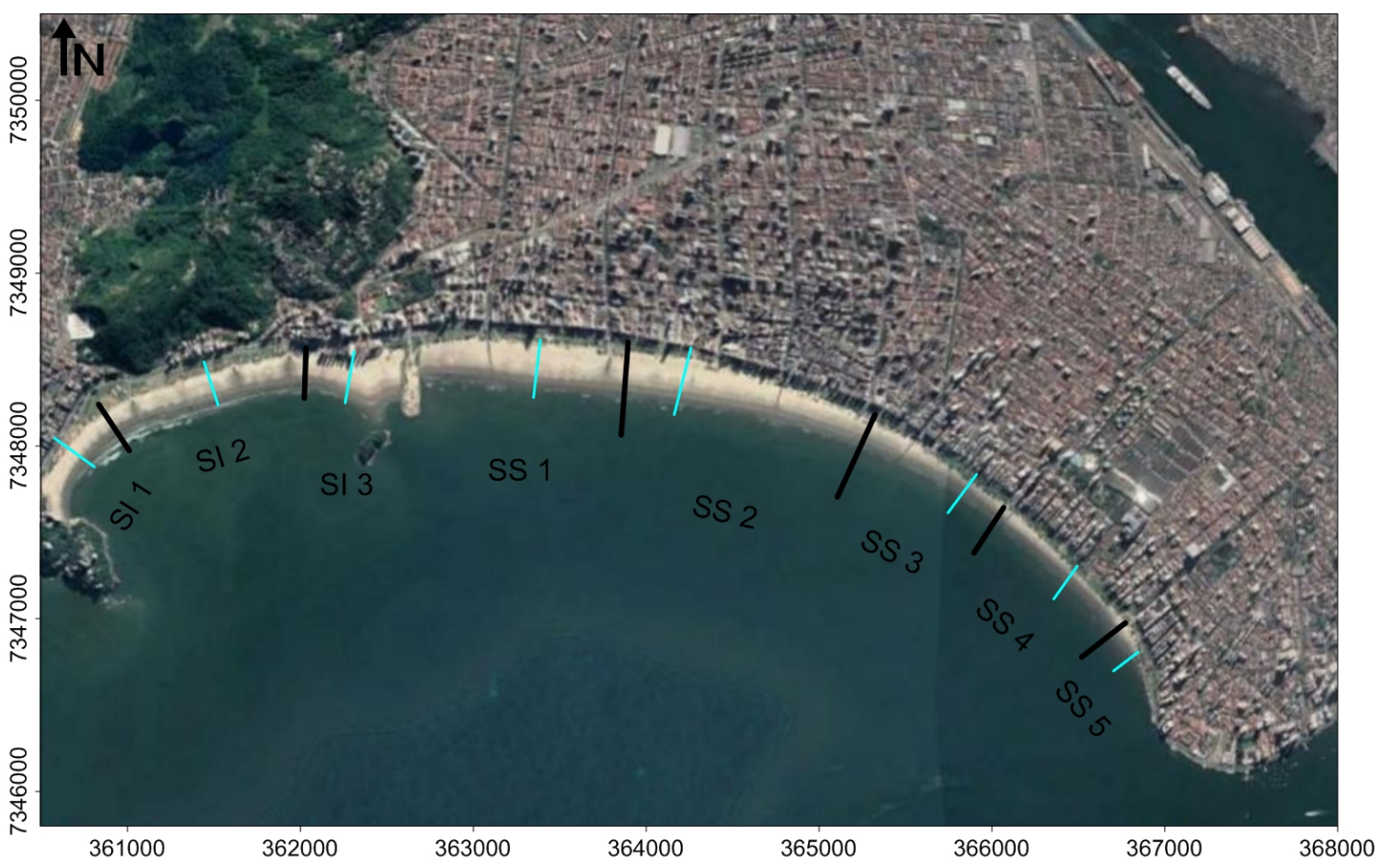

Figura 6.1: Imagem indicando os 5 setores nos quais a praia de Santos foi dividida e os 3 setores da praia da Itararé (As linhas pretas separam os setores). As linhas azuis indicam os perfis extraídos de cada setor.

\subsection{Resultados}

Confrome descrito, os cenários foram definidos buscando a representação de altura de onda e período associado mais frequentes, assim como para a maré meteorológica. A partir dessas frequências foi possível calcular probabilidade de ocorrência de cada cenário. $\mathrm{O}$ cálculo foi realizado considerando os eventos de sobrelevação ${ }_{\text {onda }}$, maré meteorológica e maré de sizígia/quadratura como eventos simultâneos independentes. Apenas para os casos de ondas de 4.5 m e $13 \mathrm{~s}$ de pico e a de $4.8 \mathrm{~m}$ e $8 \mathrm{~s}$ de pico a probabilidade não foi calculada, por ser um caso específico observado na série temporal.

A Tabela 3 mostra a probabilidade de ocorrência de cada cenário de sobrelavagem, onde os tons esverdeados indicam uma maior chance de ocorrência e os tons avermelhados indicam menor chance de ocorrer. A probabilidade de ser maré de sizígia é a mesma de quadratura, pois ambas possuem a mesma quantidade de ocorrência ao longo do ano. Portanto a tabela representa a probabilidade tanto da maré de sizígia quanto de quadratura. 
Tabela 3: Probabilidade ocorrência dos cenários de sobrelavagem, onde as colunas são os cenários de maré meteorológica e as linhas de sobrelevação ${ }_{\text {onda }}$. A tabela indica a probabilidade tanto para Maré de Sizígia quanto Quadratura, pois estes têm a mesma chance de ocorrência. Os valores mais próximos do verde tem mais chances de ocorrer do os valores em tons vermelhos.

\begin{tabular}{|c|c|c|c|c|c|}
\hline Hs/Tp\MM & $\mathbf{0 . 0 m}$ & $\mathbf{0 . 5 m}$ & $\mathbf{0 . 7 5 m}$ & $\mathbf{1 . 0 m}$ & $\mathbf{1 . 2 m}$ \\
\hline $\mathbf{1 . 0 m} / \mathbf{8 s}$ & $5.43656 \%$ & $1.56451 \%$ & $0.45856 \%$ & $0.05640 \%$ & $0.00981 \%$ \\
\hline $\mathbf{1 . 5 m} / \mathbf{8 s}$ & $5.36338 \%$ & $1.54345 \%$ & $0.45239 \%$ & $0.05564 \%$ & $0.00968 \%$ \\
\hline $\mathbf{2 . 0 m} / \mathbf{8 s}$ & $2.36369 \%$ & $0.68021 \%$ & $0.19937 \%$ & $0.02452 \%$ & $0.00426 \%$ \\
\hline $\mathbf{2 . 5 m} / \mathbf{8 s}$ & $1.14492 \%$ & $0.32948 \%$ & $0.09657 \%$ & $0.01188 \%$ & $0.00207 \%$ \\
\hline $\mathbf{3 . 0 m} / \mathbf{9 s}$ & $0.45371 \%$ & $0.13057 \%$ & $0.03827 \%$ & $0.00471 \%$ & $0.00082 \%$ \\
\hline $\mathbf{3 . 5 m} / \mathbf{9 s}$ & $0.13638 \%$ & $0.03925 \%$ & $0.01150 \%$ & $0.00141 \%$ & $0.00025 \%$ \\
\hline $\mathbf{4 . 0 m} / \mathbf{1 0 s}$ & $0.03193 \%$ & $0.00919 \%$ & $0.00269 \%$ & $0.00033 \%$ & $0.00006 \%$ \\
\hline $\mathbf{4 . 5 m} / \mathbf{8 s}$ & $0.02528 \%$ & $0.00728 \%$ & $0.00213 \%$ & $0.00026 \%$ & $0.00005 \%$ \\
\hline $\mathbf{4 . 5 m} / \mathbf{1 3 s}$ & - & - & - & - & - \\
\hline $\mathbf{4 . 8 m} / \mathbf{8 s}$ & - & - & - & - & - \\
\hline $\mathbf{5 . 0 m} / \mathbf{8 s}$ & $0.00399 \%$ & $0.00115 \%$ & $0.00034 \%$ & $0.00004 \%$ & $0.00001 \%$ \\
\hline
\end{tabular}

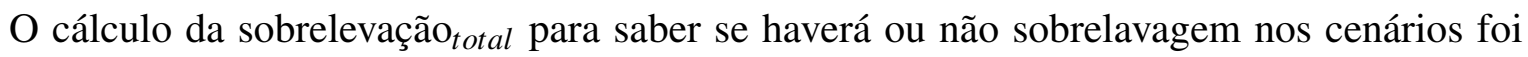
realizado para os mesmos setores usados no estudo da morfologia da praia em ambas as praias estudadas, Santos e Itararé. Os resultados são mostrados separadamente para cada setor do arco praial. Para cada setor foi obtido resultados da sobrelevação ${ }_{t o t a l}$ em cada cenário, para maré de

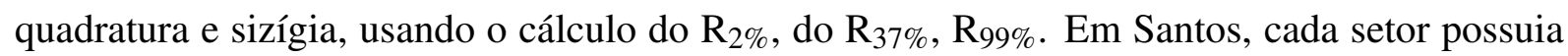
a altura do muro, no local do perfil extraído, para Itararé a altura do muro foi considerada com uma média dos valores obtidos para Santos, ou seja $2.2 \mathrm{~m}$.

O setor 1 da praia de Santos corresponde ao setor da mais próximo ao Emissário Submarino, onde a praia é mais larga e possui uma declividade aproximada de $0.68^{\circ}$. Neste setor a altura do calçadão obtida foi de $2.4 \mathrm{~m}$, este foi o valor usado para saber haveria sobrelavagem nessa região da praia (Figura 6.2).

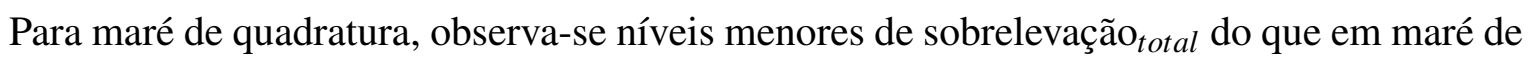
sizígia. Nota-se também o $\mathrm{R}_{2} \%$ resulta em valores menores e o $\mathrm{R}_{99 \%}$ apresenta níveis mais altos

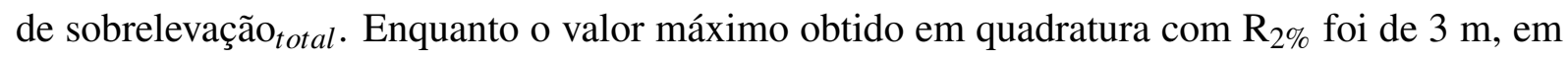
sizígia com $\mathrm{R}_{99 \%}$ o valor máximo atingiu $4.8 \mathrm{~m}$. O $\mathrm{R}_{37 \%}$ apresentou resultados semelhantes ao $\mathrm{R}_{2 \%}$, tanto em quadratura quanto em sizígia.

Nas condições de quadratura combinada com $\mathrm{R}_{2} \%$ e $\mathrm{R}_{37 \%}$ foram poucos os cenários que

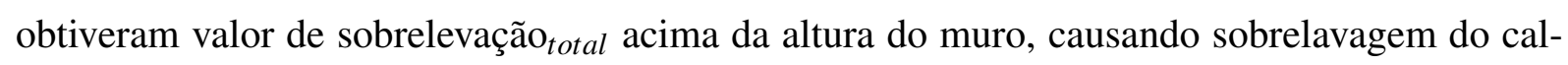
çadão. Observa-se mais sobrelavagem a partir da quadratura com $\mathrm{R}_{99 \%}$ e nos cenários de maré de sizígia, nos quais é possível observar sobrelavagem até nos cenários de maré meteorológica nula. O cenário de altura significativa de onda de $4.5 \mathrm{~m}$ e período de pico de $13 \mathrm{~s}$ de pico apresentou os maiores valores de sobrelevação ${ }_{t o t a l}$, gerando inundação em diversos cenários. Contudo, os cenários que possuem maior probabilidade de ocorrência não indicaram sobrelavagem neste setor da praia de Santos. 


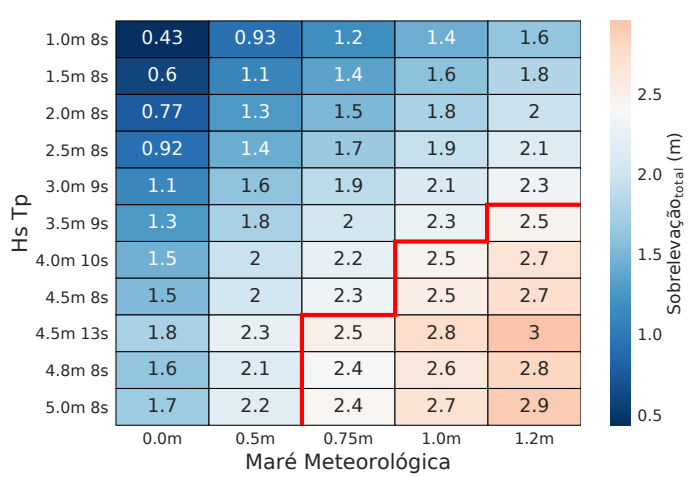

(a) Quadratura $\mathrm{R}_{2 \%}$

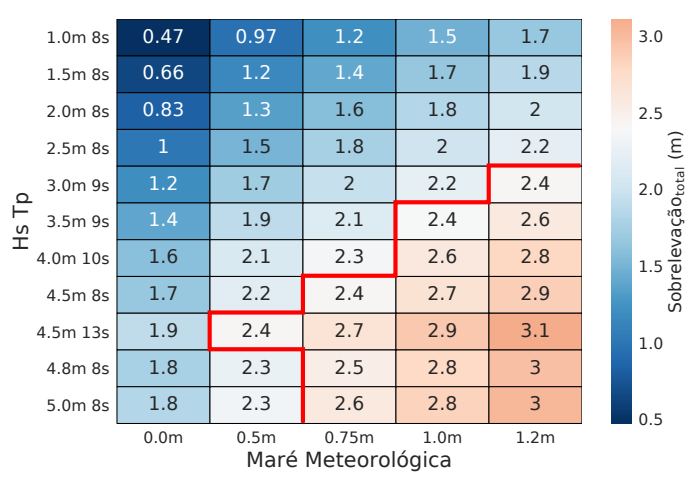

(c) Quadratura $\mathrm{R}_{37 \%}$

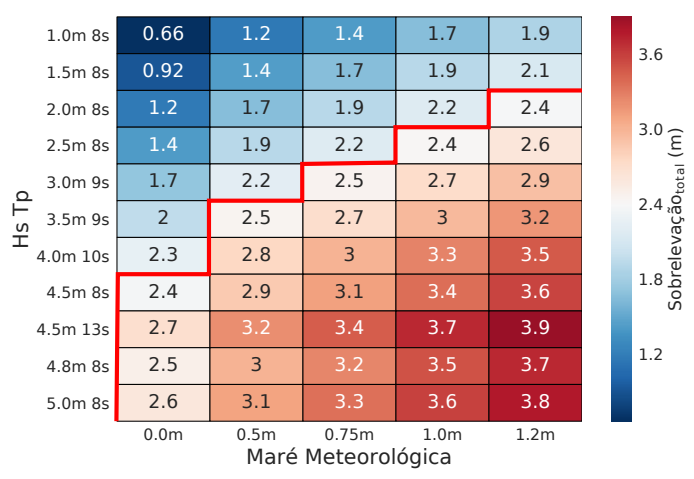

(e) Quadratura R99\%

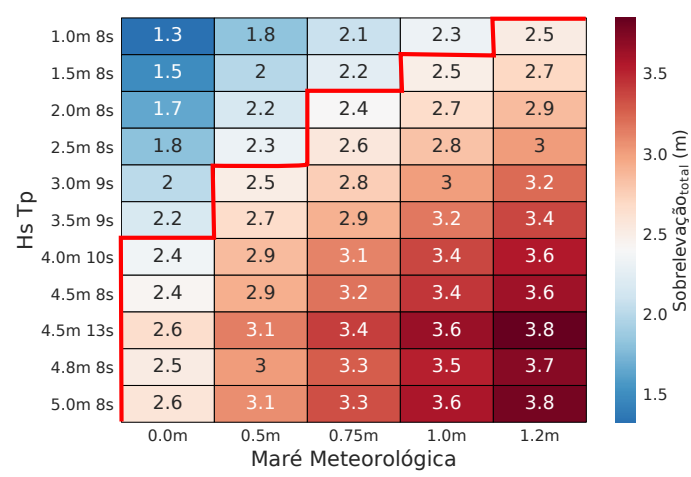

(b) Sizígia $\mathrm{R}_{2} \%$

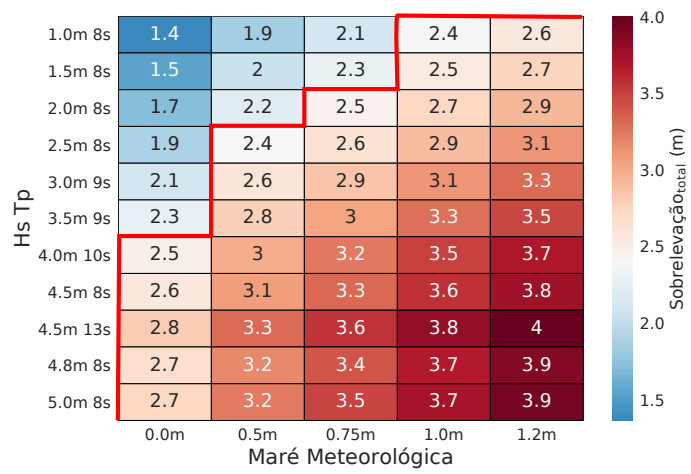

(d) Sizígia $\mathrm{R}_{37 \%}$

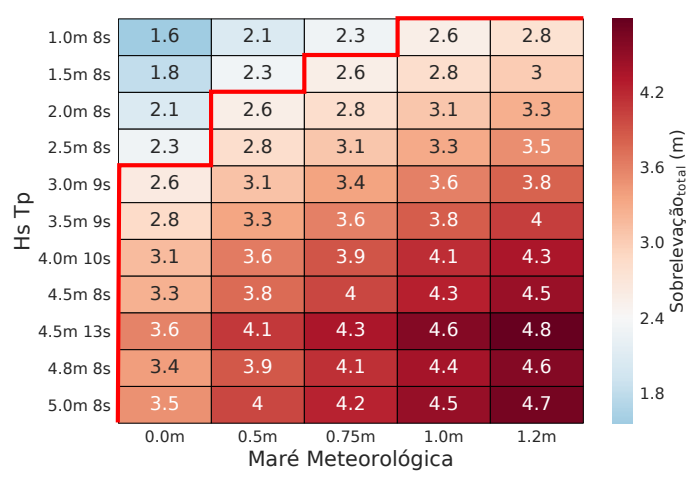

(f) Sizígia $\mathrm{R}_{99 \%}$

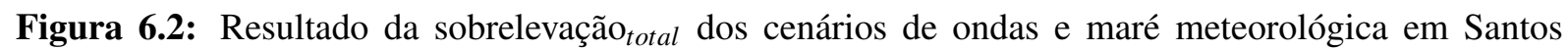
no setor 1 - Altura do calçadão $=2.4 \mathrm{~m}$. A linha vermelha representa a divisão entre valores de

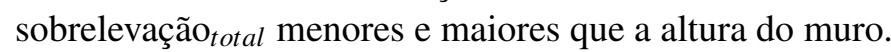

O setor 2 de Santos está localizado na região centro-oeste da praia de Santos, este setor ainda possui extensa faixa de areia e declividade aproximada de $0.45^{\circ}$ e possui altura do calçadão igual a $2.1 \mathrm{~m}, 30 \mathrm{~cm}$ a menos que no setor 1 . Apesar de apresentar níveis mais baixo de sobrelevação total $_{\text {nos }}$ cenários, observa-se que este setor apresenta mais sobrelavagem que o setor 1, devido a menor altura de muro no calçadão(Figura 6.3).

Assim como foi visto no setor anterior, na maré de quadratura, observa-se níveis menores de

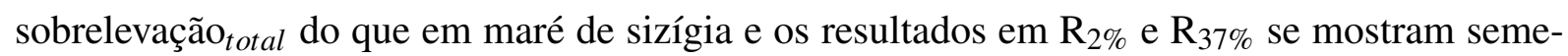


lhantes independente da maré. Em maré de sizígia pode-se notar a ocorrência de sobrelavagem até nos cenários com Hs abaixo $2 \mathrm{~m}$, quando combinados com maré meteorológica extrema. $\mathrm{O}$ $\mathrm{R}_{99 \%}$ apresentou níveis mais altos de sobrelevação ${ }_{\text {total }}$, atingindo $4.6 \mathrm{~m}$ em sizígia, enquanto nas condições de quadratura combinada com $\mathrm{R}_{2} \%$ e $\mathrm{R}_{37 \%}$ foram poucos os cenários que obtive-

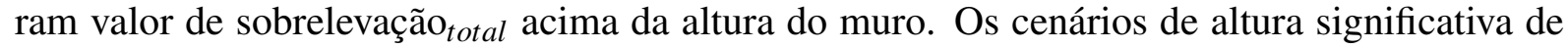
onda acima de $4.5 \mathrm{~m}$, no geral, apresentaram maiores chances de gerar sobrelavagem. No entanto, mesmo os cenários com maior probabilidade de ocorrer não apresentaram sobrelavagem no setor 2 .

A região centro-leste da praia de Santos setor 3, possui faixa de areia menos extensa e declividade aproximada de $0.80^{\circ}$, onde a altura do calçadão é de $2.2 \mathrm{~m}$, apenas $10 \mathrm{~cm}$ a mais que no setor 2. Como já foi observado nos setores anteriores os resultados para $\mathrm{R}_{2} \%$ com maré de quadratura mostram poucos cenários que causam a sobrelavagem do calçadão, mas que tendem a aumentar para $\mathrm{R}_{99 \%}$ e em maré de sizígia (Figura 6.4).

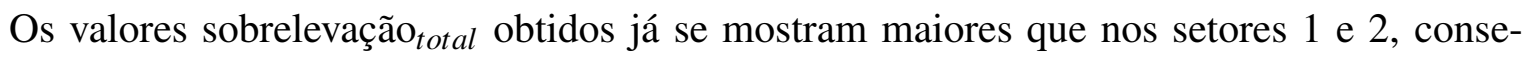
quentemente se observa mais casos de sobrelavagem. Neste setor observa-se o valor máximo de sobrelevação ${ }_{\text {total }}$ em $\mathrm{R}_{2 \%}$ e maré de quadratura igual a $3.1 \mathrm{~m}$, maior do que foi visto nos setores 1 e 2. Os resultados são mais intensos quando colocamos a maré de quadratura asso-

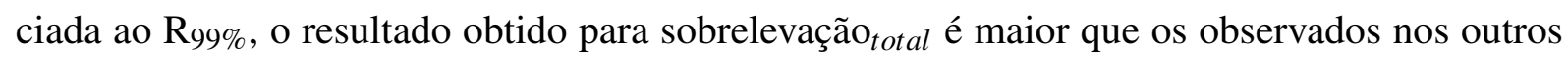
cálculos de sobrelevação ${ }_{\text {onda }}$ calculados, gerando cenários que resultam em sobrelavagem do calçadão. Na maré de sizígia, com já esperado, cálculo com $\mathrm{R}_{2 \%}$, já indica sobrelavagem em mais da metade dos cenários. O R99\% em maré de sizígia, resultou em sobrelevação ${ }_{t o t a l}$ máxima de $5 \mathrm{~m}, 2.7 \mathrm{~m}$ acima do muro nesse setor.

O setor 4 de Santos se encontra na porção mais a leste da praia de Santos já próximo da do canal do porto, mas ainda não incluindo a Ponta da Praia. Neste setor a faixa de areia é estreita e a declividade é próxima de $0.85^{\circ}$. A altura do calçadão registrada nesse setor foi 2.1 $\mathrm{m}$, devido a maior declividade da praia e menor altura do muro é possível observar mais casos de sobrelavagem do calçadão.

Este setor apresenta a mesma altura de muro do calçadão que o setor 2, contudo, por ser mais inclinado que o setor 2 nota-se que os resultados de sobrelevação total $_{\text {apresentam valores }}$ maiores (Figura 6.5). É possível observar vários cenários com sobrelevação total já nos casos de maré de quadratura associada ao $\mathrm{R}_{99 \%}$, o que não acontecia nos outros setores de Santos.

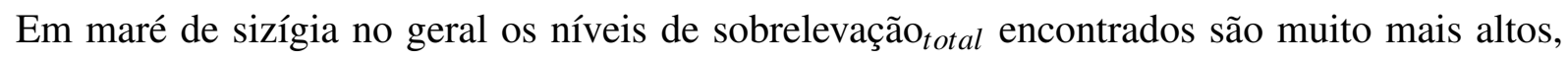
consequentemente obtém-se sobrelevação ${ }_{t o t a l}$ em quase todos os cenários. Apenas 5 cenários não resultaram em sobrelavagem no caso de $\mathrm{R}_{2} \%$ e maré de sizígia. A sobrelevação ${ }_{\text {total }}$ máxima observada nesse setor é de $5.1 \mathrm{~m}$, o que corresponde a $2.4 \mathrm{~m}$ acima do muro. Neste trecho de Santos alguns cenários que possuem maior probabilidade de ocorrência indicaram a possibilidade de haver sobrelavagem do muro. 


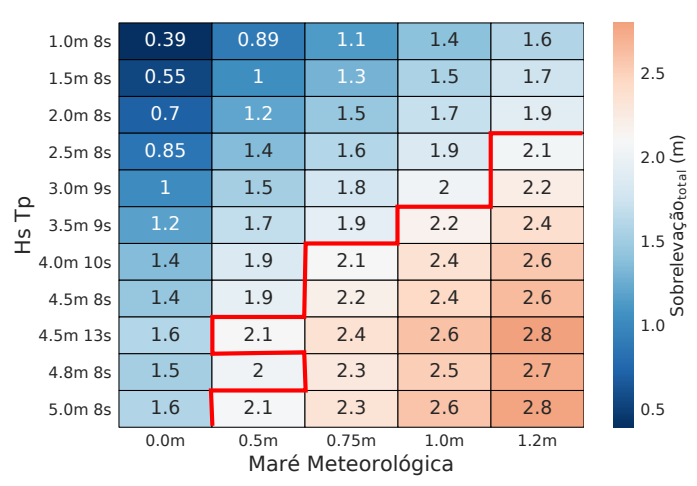

(a) Quadratura $\mathrm{R}_{2 \%}$

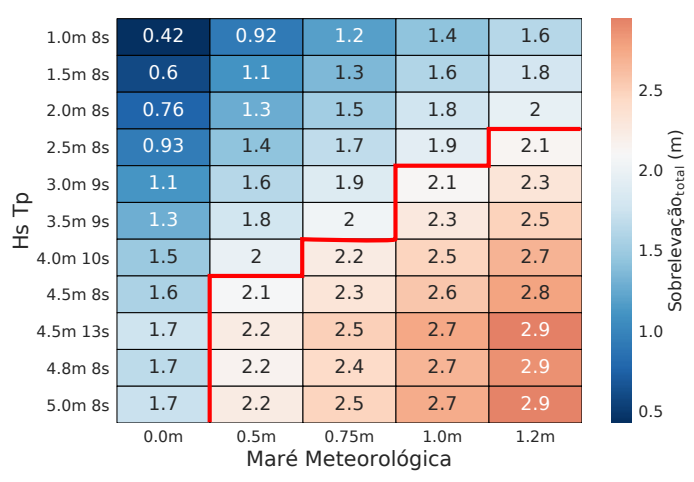

(c) Quadratura $\mathrm{R}_{37 \%}$

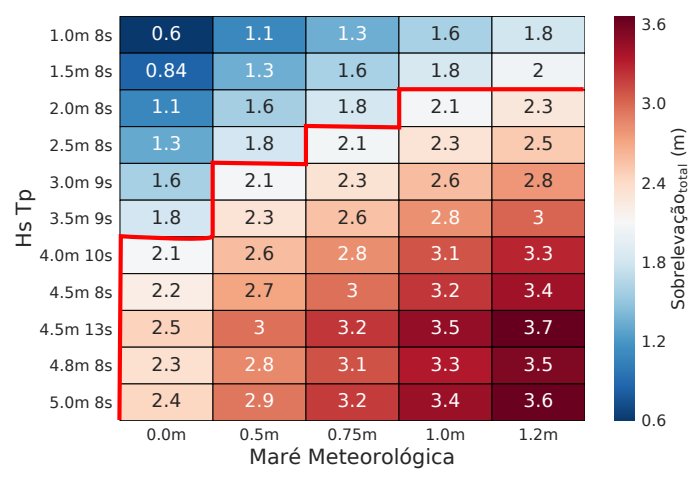

(e) Quadratura R99\%

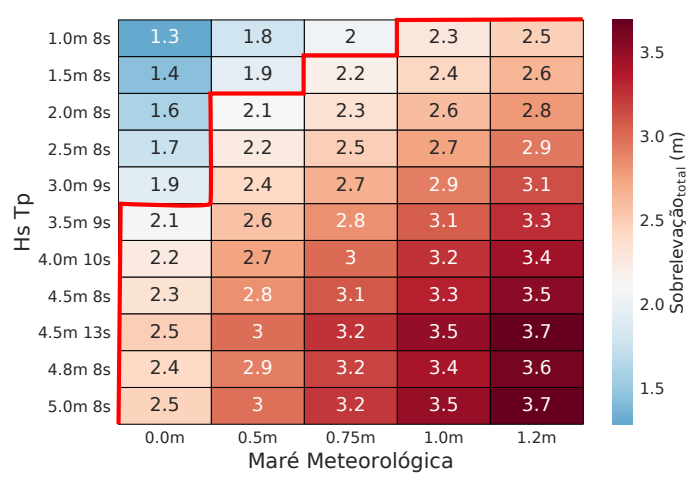

(b) Sizígia $\mathrm{R}_{2 \%}$

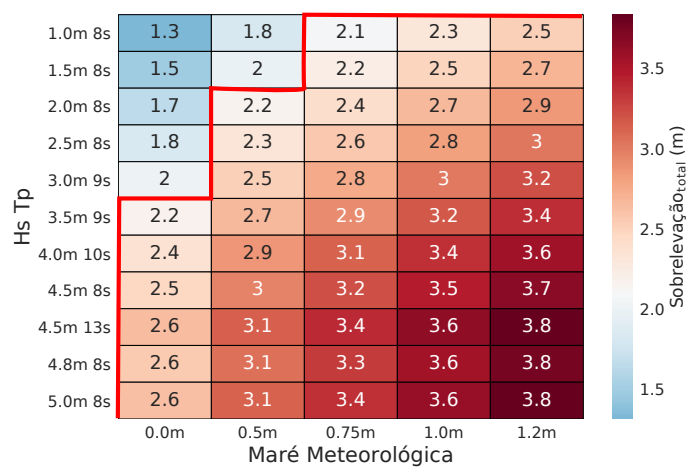

(d) Sizígia $\mathrm{R}_{37 \%}$

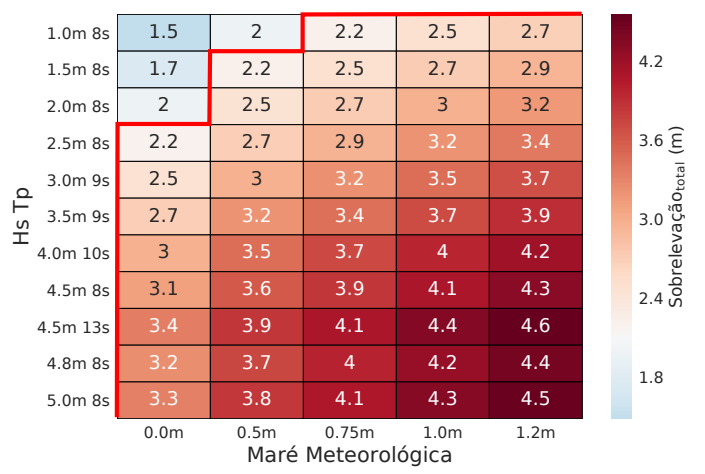

(f) Sizígia R99\%

Figura 6.3: Resultado da sobrelevação ${ }_{t o t a l}$ dos cenários de ondas e maré meteorológica em Santos no setor 2 - Altura do calçadão $=2.1 \mathrm{~m}$. A linha vermelha representa a divisão entre valores de sobrelevação $\mathrm{o}_{\text {total }}$ menores e maiores que a altura do muro. 


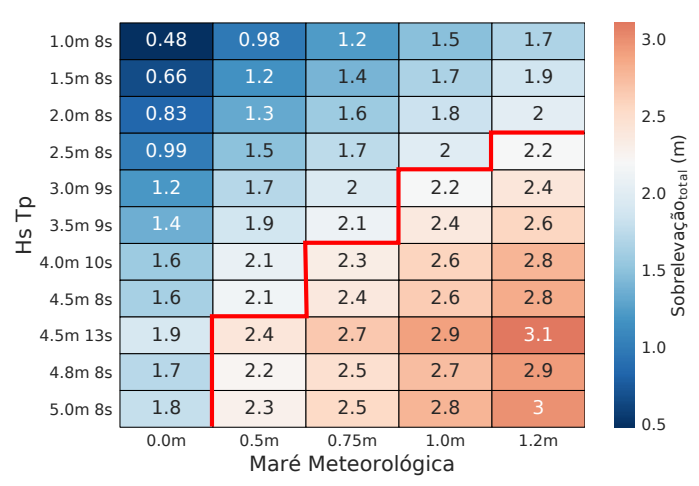

(a) Quadratura $\mathrm{R}_{2 \%}$

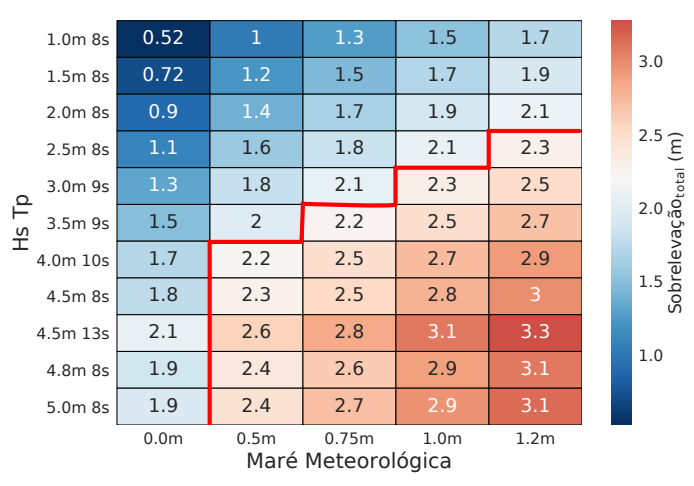

(c) Quadratura $\mathrm{R}_{37 \%}$

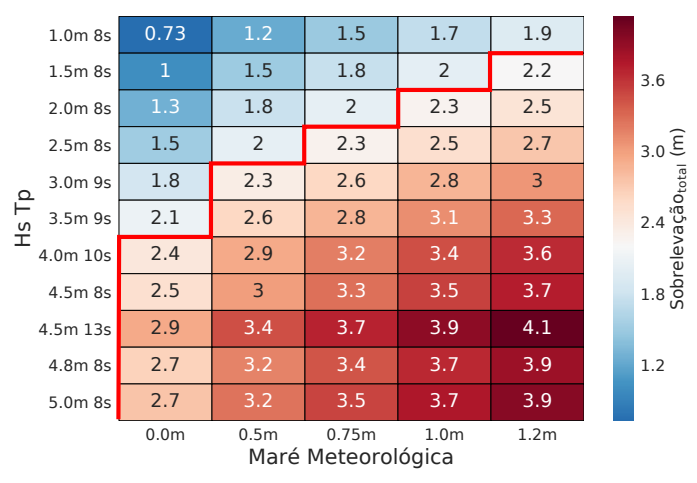

(e) Quadratura R99\%

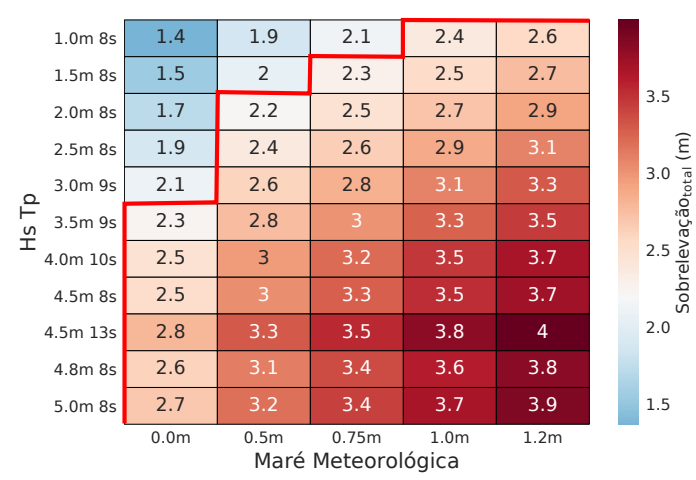

(b) Sizígia $\mathrm{R}_{2 \%}$

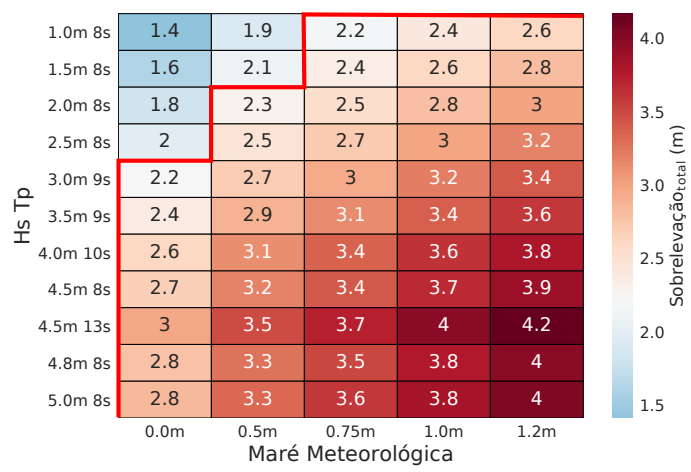

(d) Sizígia $\mathrm{R}_{37 \%}$

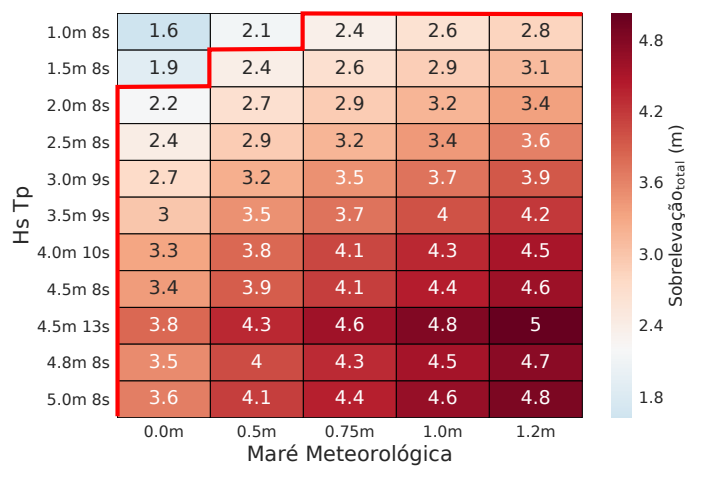

(f) Sizígia R99\%

Figura 6.4: Resultado da sobrelevação ${ }_{t o t a l}$ dos cenários de ondas e maré meteorológica em Santos no setor 3 - Altura do calçadão $=2.2 \mathrm{~m}$. A linha vermelha representa a divisão entre valores de sobrelevação $\mathrm{o}_{\text {total }}$ menores e maiores que a altura do muro. 


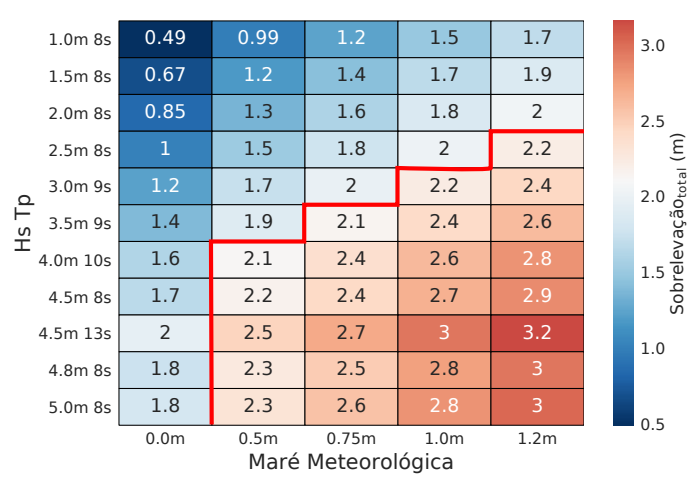

(a) Quadratura $\mathrm{R}_{2 \%}$

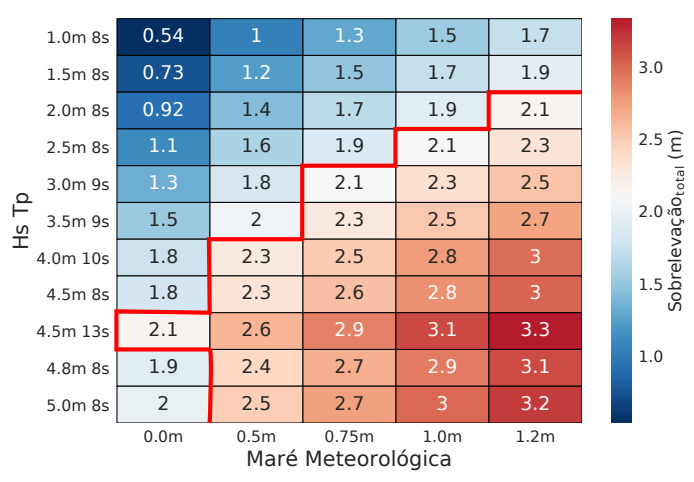

(c) Quadratura $\mathrm{R}_{37 \%}$

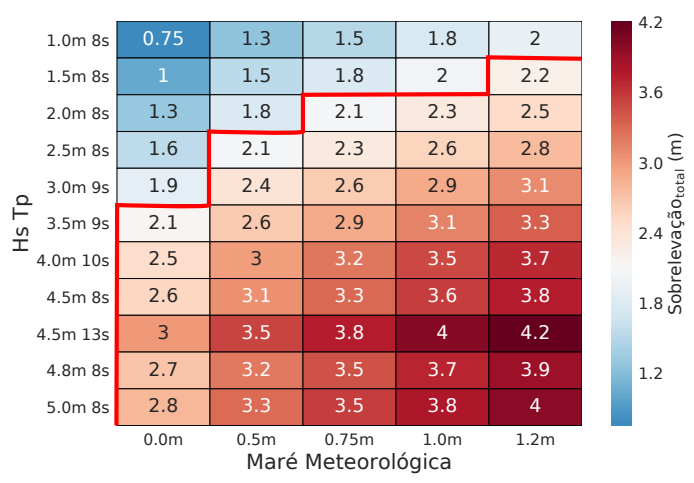

(e) Quadratura R99\%

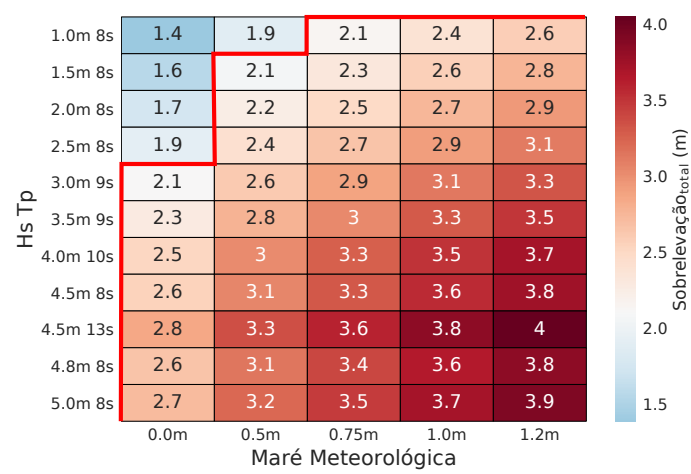

(b) Sizígia $\mathrm{R}_{2 \%}$

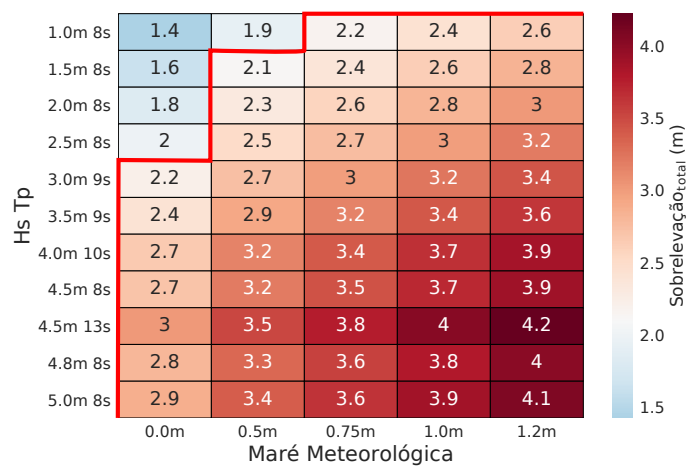

(d) Sizígia $\mathrm{R}_{37 \%}$

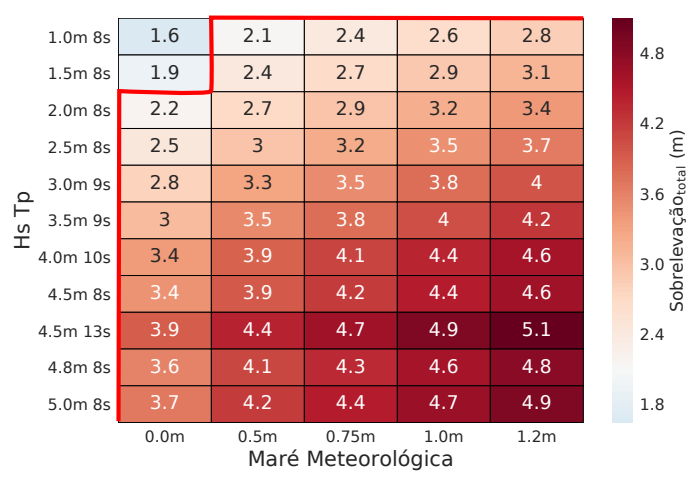

(f) Sizígia R99\%

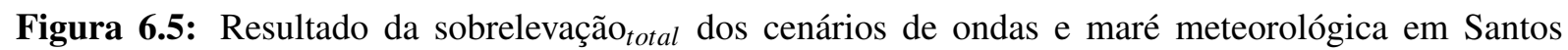
no setor 4 - Altura do calçadão $=2.1 \mathrm{~m}$. A linha vermelha representa a divisão entre valores de

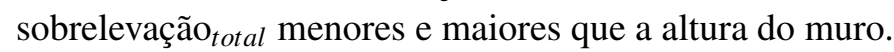




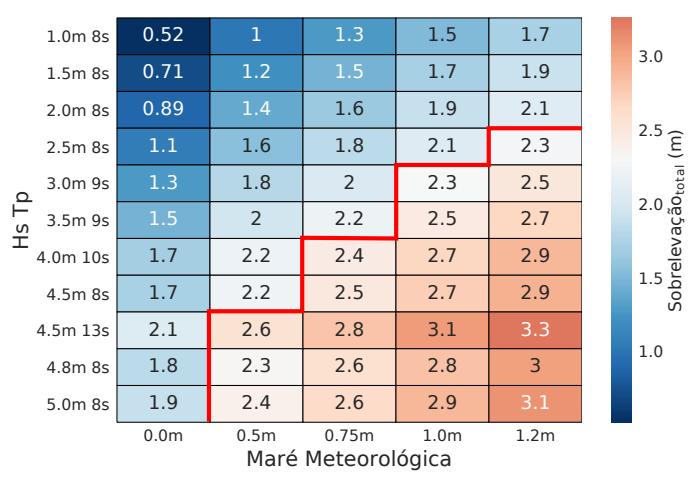

(a) Quadratura $\mathrm{R}_{2 \%}$

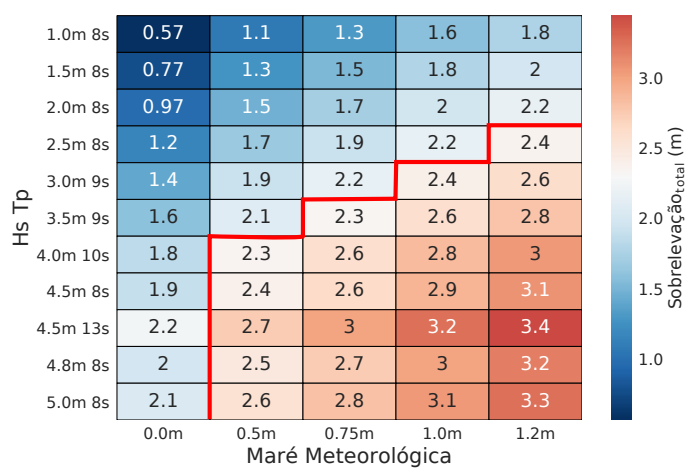

(c) Quadratura $\mathrm{R}_{37 \%}$

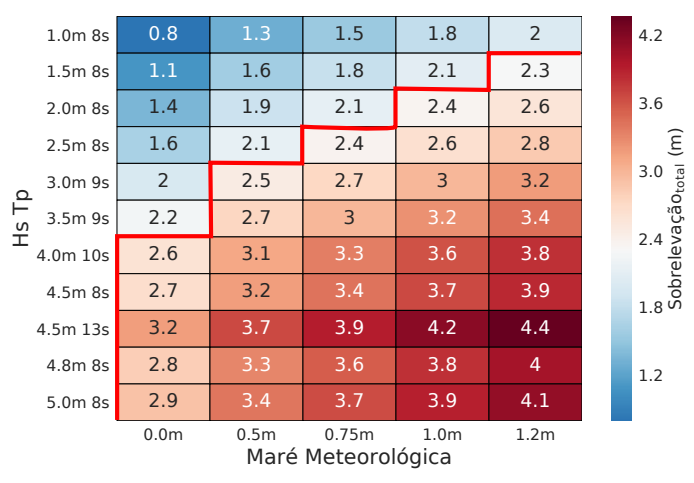

(e) Quadratura R99\%

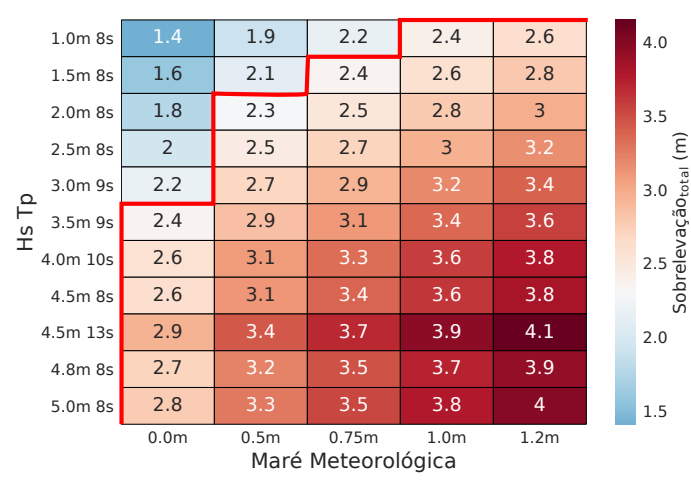

(b) Sizígia $\mathrm{R}_{2} \%$

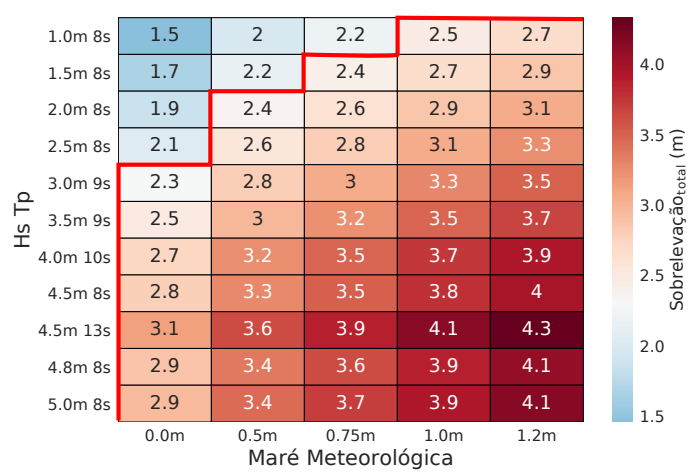

(d) Sizígia $\mathrm{R}_{37 \%}$

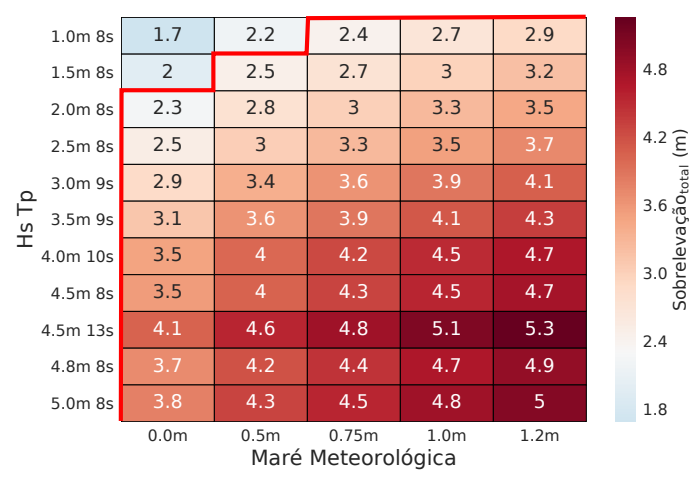

(f) Sizígia $\mathrm{R}_{99 \%}$

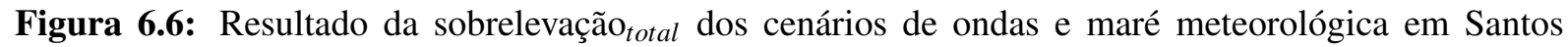
no setor 5 - Altura do calçadão $=2.3 \mathrm{~m}$. A linha vermelha representa a divisão entre valores de sobrelevação $\mathrm{o}_{\text {total }}$ menores e maiores que a altura do muro.

A Ponta da Praia em Santos (setor 5) que se localiza no extremo leste da praia de Santos, foi analisada separadamente. Neste setor a faixa de areia é estreita, similar ao setor 4, e apresenta declividade de $0.97^{\circ}$. A ponta da Praia também sofre realimentação artificial, realizada pela prefeitura de Santos com areia trazida dos canais mais centrais e a oeste. A altura do muro nesse setor é $2.3 \mathrm{~m}$, mais alta que no setor 4 .

Este setor apresenta características semelhantes ao setor 4, contudo sofre mais com as ações humanas, devido sua proximidade com o canal do porto e presença do muro do calçadão que 
continua para leste após o termino da faixa de areia. Sendo assim, os níveis de sobrelevação total $_{\text {ta }}$ obtidos são ligeiramente maiores que os encontrados nos outros setores de Santos (Figura 6.6). Apesar dos maiores valores de sobrelevação ${ }_{\text {total }}$, a sobrelavagem aparecem em menos cenários que no setor 4, onde a altura do calçadão é menor.

É possível observar valores de $3.3 \mathrm{~m}$ de sobrelevação total $_{\text {no }}$ no cenário de $\mathrm{Hs}=4.5 \mathrm{~m}, \mathrm{Tp}=13 \mathrm{~s}$ e $1.2 \mathrm{~m}$ de maré, em caso de maré de quadratura e $\mathrm{R}_{2} \%$, um valor bem elevado comprativamente os setores da porção oeste da praia. Os cenários de onda com Hs acima de 4 m e ausência de maré meteorológica passam a apresentar sobrelavagem no R99\% em quadratura, algo que não acontecia na sobrelevação ${ }_{\text {onda }}$ de $2 \%$ e $37 \%$.

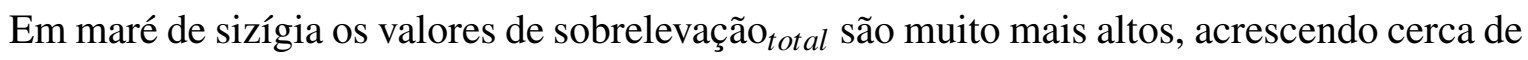
$1 \mathrm{~m}$ comparados aos cenários de maré de quadratura e consequentemente ocorre sobrelavagem em quase todos os cenários. Para $\mathrm{R}_{99 \%}$ em maré de sizígia, apenas os cenários com maré meteorológica nula combinada com $\mathrm{Tp}=8 \mathrm{~s}$ e, Hs de $1 \mathrm{~m}$ e $1.5 \mathrm{~m}$, e o cenário de $\mathrm{Hs}=1 \mathrm{~m}, \mathrm{Tp}=8$ s e maré meteorológica de $0.5 \mathrm{~m}$, não indicam inundação do calçadão. Estes três cenários têm as maiores probabilidades de ocorrência, acima de 5\% para os com maré meteorológica de $0 \mathrm{~m}$ e $1 \%$ para maré meteorológica de $0.5 \mathrm{~m}$. Contudo, isso não significa que os outros não podem ocorrer. A sobrelevação ${ }_{\text {total }}$ mínima observada é de $1.7 \mathrm{~m}$ e máxima é de $5.3 \mathrm{~m}$.

A praia de Itararé analisada em 3 setores, o setor 1 corresponde ao setor próximo à Ilha Porchat, onde há um tombolo fixado unindo o continente à ilha. Essa porção da praia extensa e possui uma declividade aproximada de $0.68^{\circ}$. A altura do calçadão em Itararé foi considerada $2.2 \mathrm{~m}$.

O cálculo dos cenários de maré apresentam valores semelhantes aos encontrados nos setores de Santos que possuem maior faixa de areia. No geral, em maré de quadratura combinada com $\mathrm{R}_{2 \%}, \mathrm{R}_{37 \%} \mathrm{e} \mathrm{R}_{99 \%}$, os casos de sobrelavagem ficaram restritos aos cenários mais extremos, com ondas mais intensas e/ou maré meteorológica maior. O R99\% em quadratura já apresenta valores maiores de sobrelevação ${ }_{\text {total }}$ e portanto, mais casos de sobrelavagem.

A sobrelavagem tem mais ocorrências quando calculada a sobrelevação ${ }_{\text {total }}$ com maré de sizígia, assim como foi observado também em Santos, nessas condições de onda e maré, muitos cenários apresentaram valores de sobrelevação ${ }_{\text {total }}$ igual ou acima da altura do muro. O máximo de sobrelevação ${ }_{\text {total }}$ observado neste setor é $4.9 \mathrm{~m}$, e valor mínimo é $0.45 \mathrm{~m}$. 


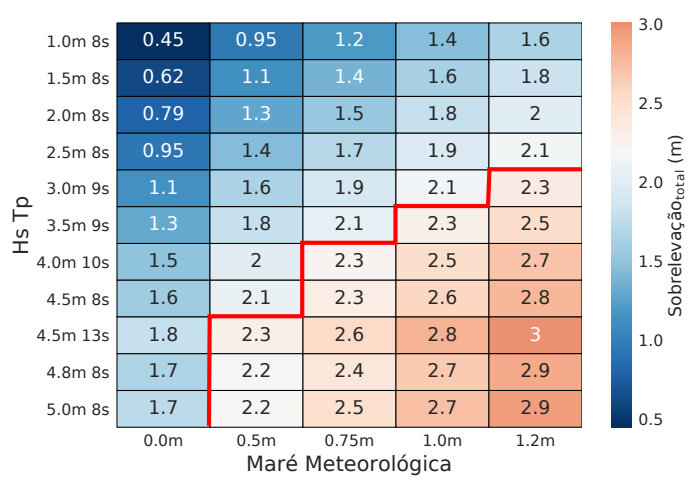

(a) Quadratura $\mathrm{R}_{2 \%}$

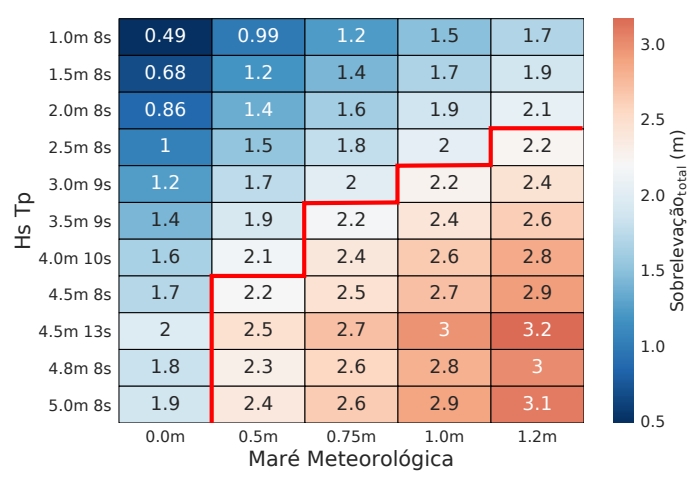

(c) Quadratura $\mathrm{R}_{37 \%}$

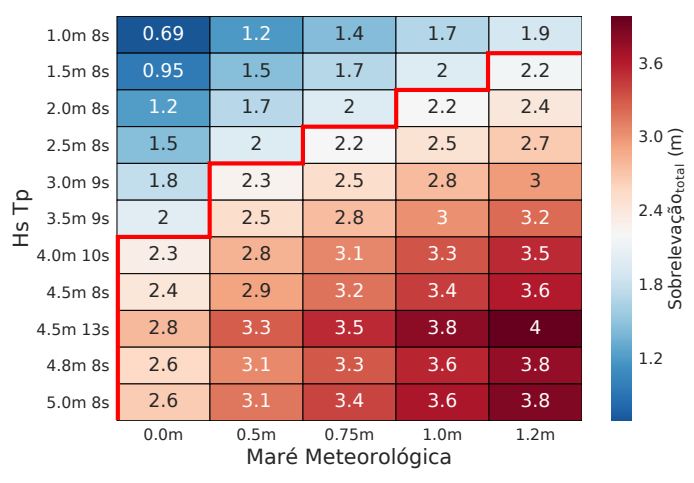

(e) Quadratura R99\%

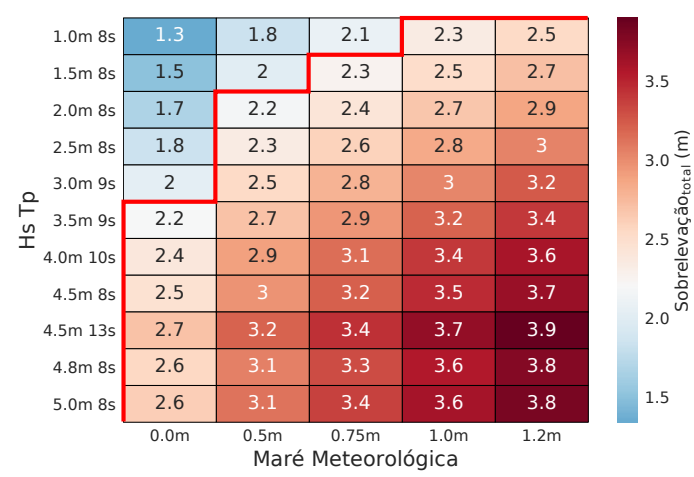

(b) Sizígia $\mathrm{R}_{2 \%}$

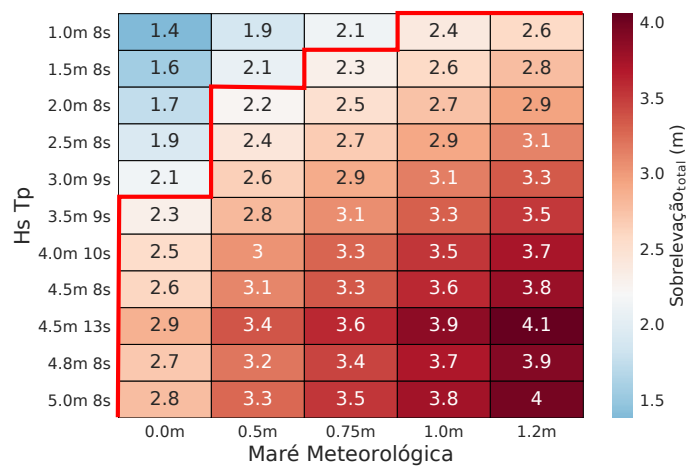

(d) Sizígia $\mathrm{R}_{37 \%}$

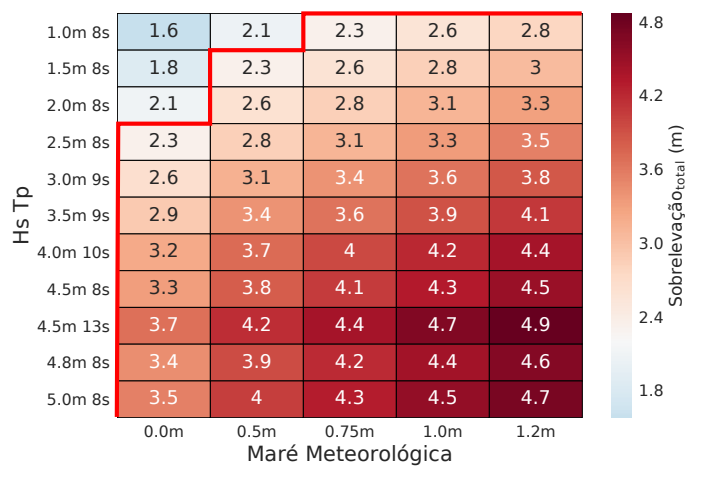

(f) Sizígia R99\%

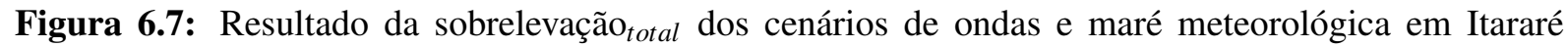
no setor 1 - Altura do calçadão $=2.2 \mathrm{~m}$. A linha vermelha representa a divisão entre valores de sobrelevação $\mathrm{o}_{\text {total }}$ menores e maiores que a altura do muro. 


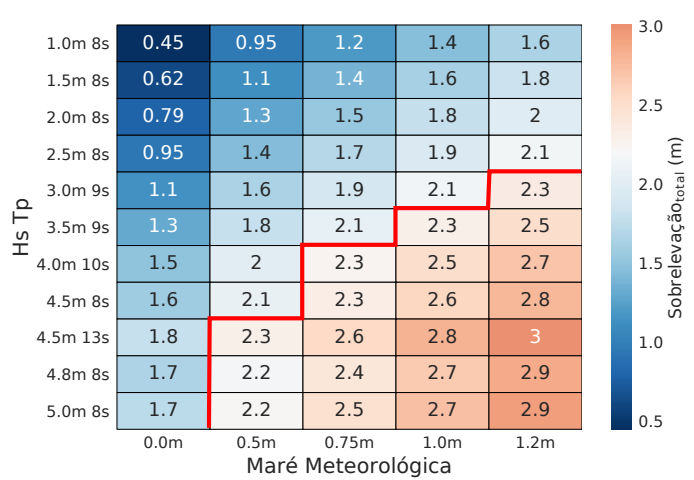

(a) Quadratura $\mathrm{R}_{2} \%$

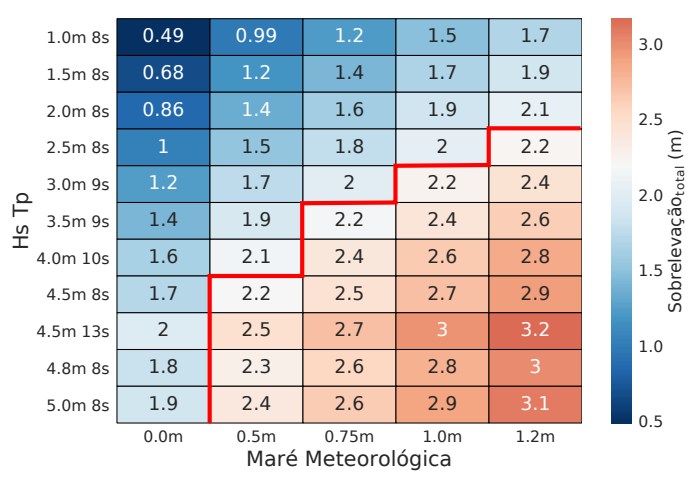

(c) Quadratura $\mathrm{R}_{37 \%}$

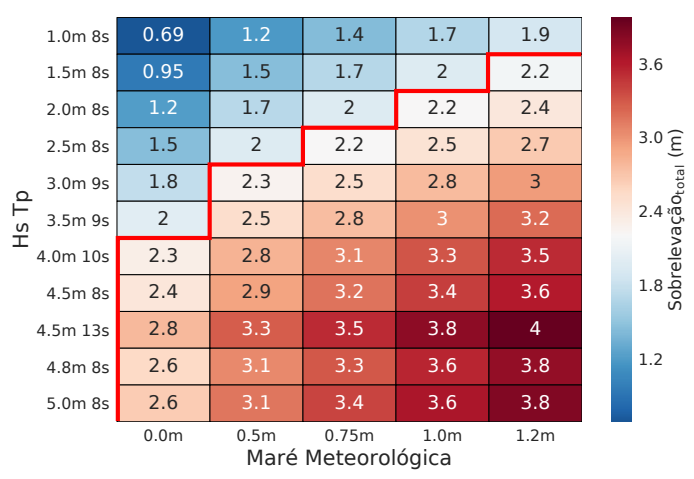

(e) Quadratura R99\%

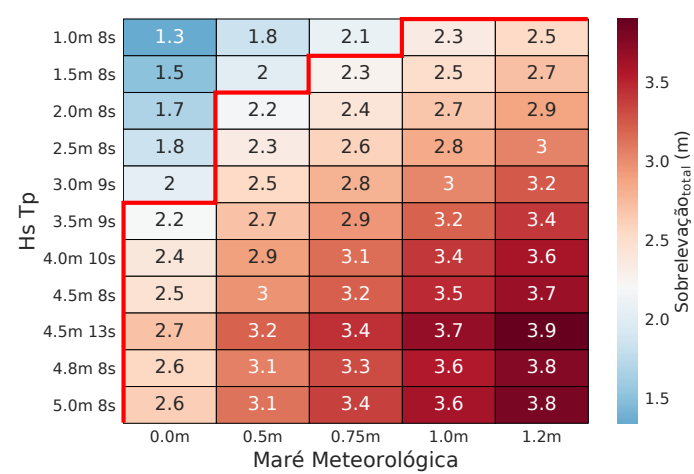

(b) Sizígia $\mathrm{R}_{2} \%$

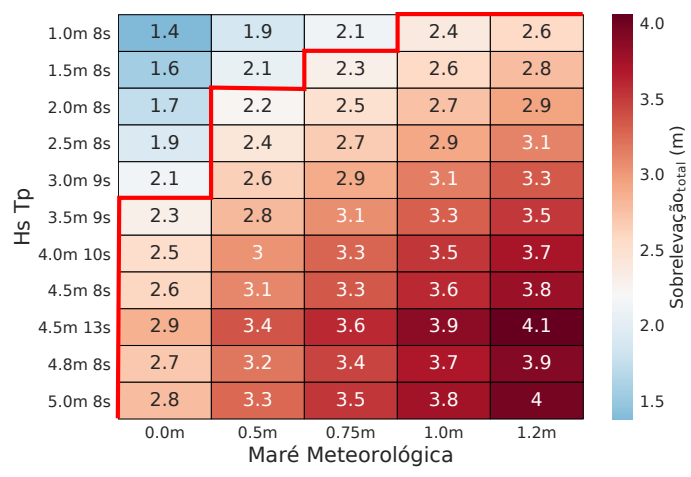

(d) Sizígia $\mathrm{R}_{37 \%}$

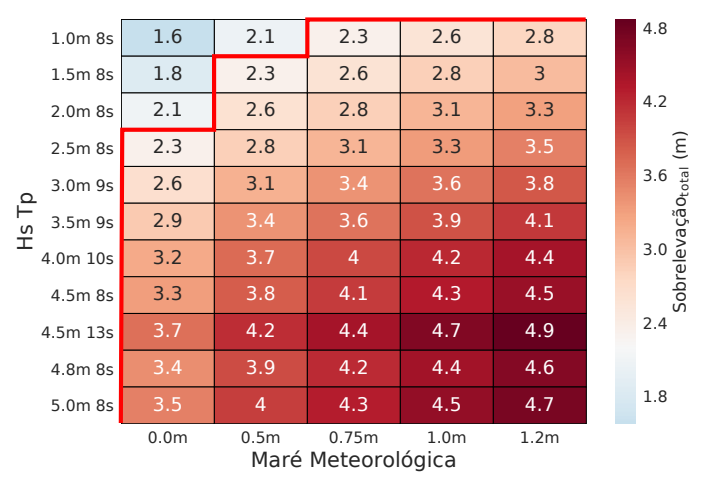

(f) Sizígia R99\%

Figura 6.8: Resultado da sobrelevação ${ }_{\text {total }}$ dos cenários de ondas e maré meteorológica em Itararé no setor 2 - Altura do calçadão $=2.2 \mathrm{~m}$. A linha vermelha representa a divisão entre valores de

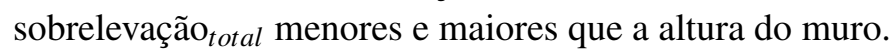

O setor 2 de Itararé representa a parte central da praia, a região menos abrigada e mais sujeito a ação das ondas. Essa porção da praia também tem faixa de areia extensa e possui uma declividade aproximada de $0.68^{\circ}$, características muito semelhantes aquelas do setor 1 de Itararé. A altura do calçadão em Itararé foi considerada $2.2 \mathrm{~m}$. Como foi utilizada a mesma altura de muro para todos os setores desta praia, e os setores 1 e 2 são muito semelhantes, os resultados foram iguais aos obtidos no setor 1. Os resultados estão representados na Figura 6.8. 


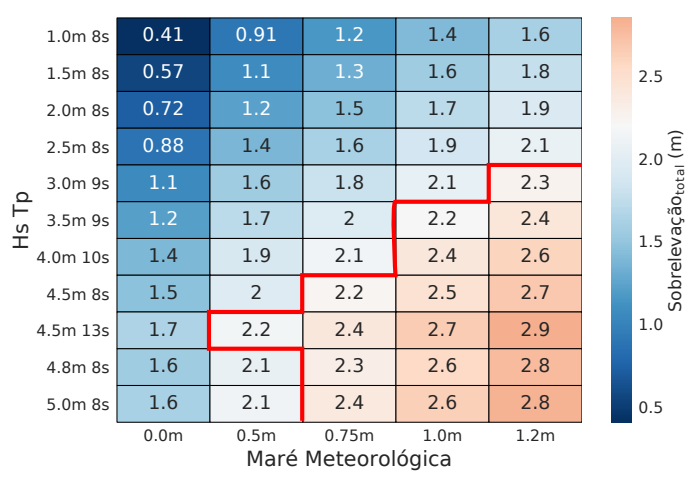

(a) Quadratura $\mathrm{R}_{2 \%}$

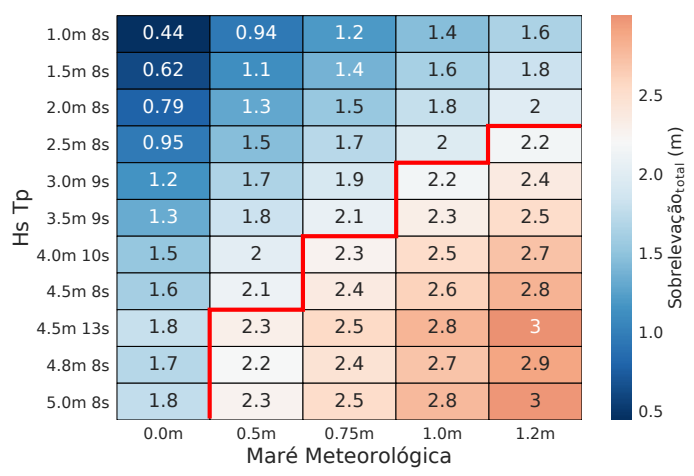

(c) Quadratura $\mathrm{R}_{37 \%}$

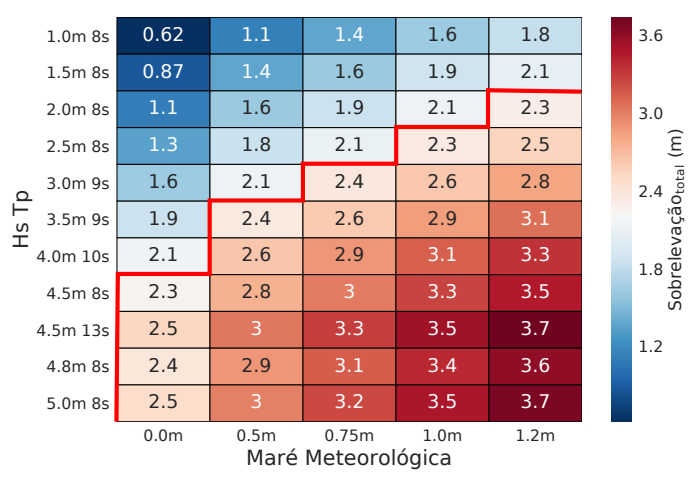

(e) Quadratura R99\%

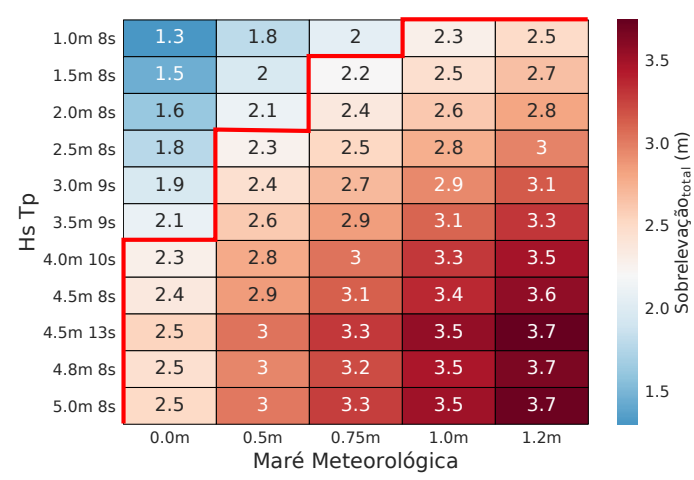

(b) Sizígia $\mathrm{R}_{2} \%$

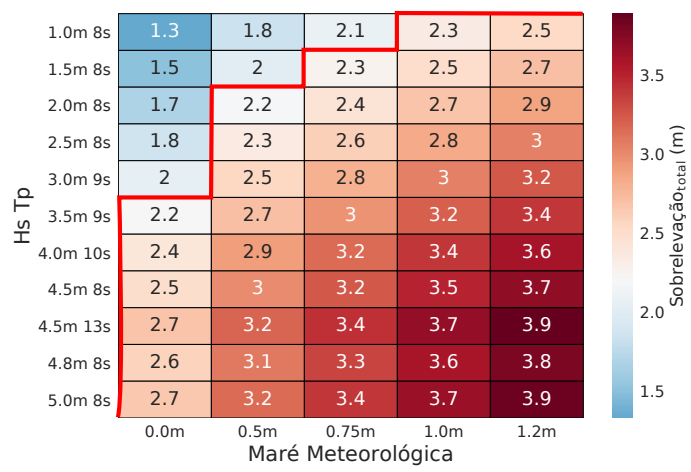

(d) Sizígia $\mathrm{R}_{37 \%}$

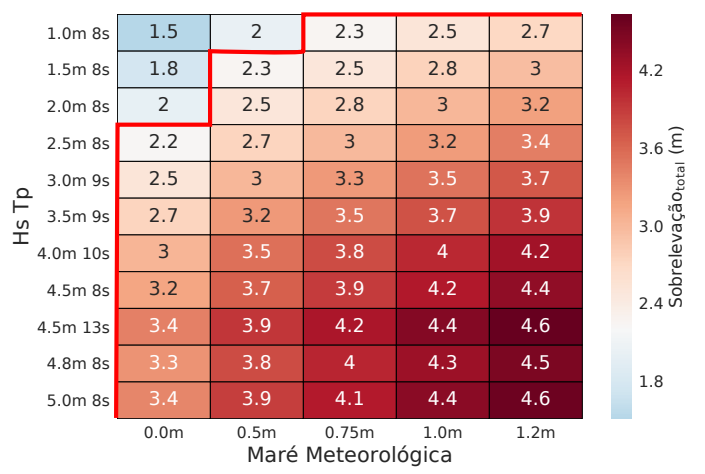

(f) Sizígia $\mathrm{R}_{99 \%}$

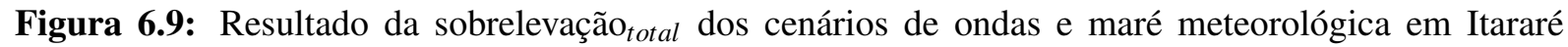
no setor 3 - Altura do calçadão $=2.2 \mathrm{~m}$. A linha vermelha representa a divisão entre valores de sobrelevação $\mathrm{o}_{\text {total }}$ menores e maiores que a altura do muro.

O setor 3 de Itararé está localizado na porção leste da praia e corresponde a zona de sombra da Ilha Urubuqueçaba. Essa porção da praia também tem faixa de areia mais extensa que os setores anteriores, devido a deposição de sedimento causado pela refração/difração das ondas na ilha. A declividade é aproximada de $0.51^{\circ}$.

Diferente dos outros setores de Itararé, as sobrelevações observadas não são tão intensas e não acarretam em tantos casos de sobrelavagem como observado nos setores 1 e 2 (Figura 6.8). Em maré de quadratura associada ao $\mathrm{R}_{37 \%}$ já se observa um aumento no valor da 


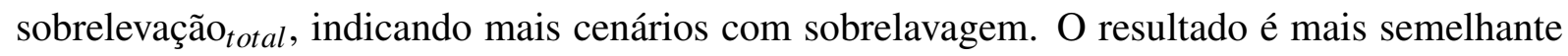
ao obtido para quadratura e $\mathrm{R}_{2 \%}$ nos setores anteriores. Já em $\mathrm{R}_{99 \%}$ os resultados são bem maiores do que os observados nos cenários de quadratura com sobrelevação ${ }_{\text {onda }}$ de $2 \%$ e $37 \%$.

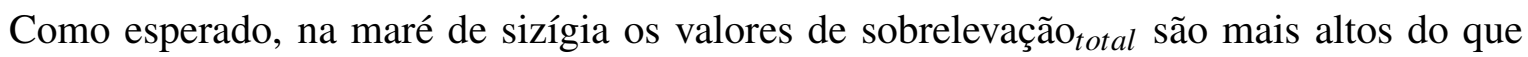
os observados em quadratura, consequentemente observa-se sobrelavagem em quase todos os cenários. Em sizígia com $\mathrm{R}_{99 \%}$ os cenários de onda com $\mathrm{Hs}$ acima de $2.5 \mathrm{~m}$ todos passam a apresentar sobrelavagem independente da maré meteorológica. Apenas Hs entre $1 \mathrm{~m}$ e 2 $\mathrm{m}$ de altura associados a $0 \mathrm{~m}$ de maré de meteorológica e $\mathrm{Hs}$ de $1 \mathrm{~m}$ associado a $0.5 \mathrm{~m}$ de maré meteorológica não sofrem sobrelavagem nestas condições de sizígia e sobrelevação ${ }_{\text {onda }}, \mathrm{o}$ resultado foi o mesmo que o observado nos setores 1 e 2 apesar deste setor apresentar valores de sobrelevação ${ }_{\text {total }}$ ligeiramente menores.

\subsection{Discussão}

O regime de sobrelavagem ao longo de uma praia urbanizada pode ser avaliado usando métodos baseadas em campo ou modelos numéricos baseados em cálculos dos processos. Embora a aplicação de modelos baseados em campo seja restrita pelo registro observacional, inibindo extrapolações além das condições experimentais, os modelos numéricos baseados em processos são altamente exigentes em dados de entrada e calibração (Silveira et al. 2016).

A abordagem utilizada neste estudo se baseou nos trabalhos de Silveira et al. (2016) e Mase et al. (2013), seguindo um esquema para a avaliação de sobrelavagem através de fórmulas de previsão propostas no trabalho de Mase et al. (2013). A estratégia utilizada visa resultados de cenários prováveis de acontecer ao longo de uma praia urbanizada e morfologicamente variável. O sucesso desta estratégia baseia-se no uso de dados de onda e de topografia local para o cálculo do alcance da sobrelavagem previsto em condições de tempestade e não-tempestade.

Os resultados obtidos, para as praias de Santos e Itararé segundo os cenários indicados, nos permitem definir o limite para a sobrelavagem em diferentes trechos da praia. Foi observado que quanto maior a declividade do perfil, maior será o sobrelevação ${ }_{\text {onda }}$ resultando em uma

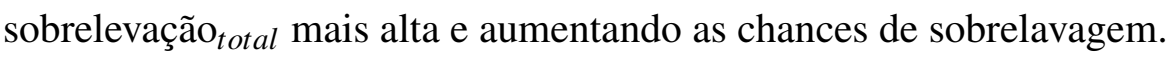

Assim como no estudo da morfodinâmica das praias, aqui também as praias foram analisadas em setores com mesmas características morfológicas e hidrodinâmicas. Foram utilizados os mesmo setores do capítulo anterior e extraído um perfil em cada setor que o representasse para avaliar a sobrelavagem. Devido as diferenças dos processos atuantes, da topografia e da variação na altura do muro do calçadão foram obtidos diferentes resultados entre os setores. Contudo, em Itararé onde foi usado um valor médio fixo para o muro do calçadão de $2.2 \mathrm{~m}$, a altura não influenciou tanto os resultados.

A grande diferença entre os setores em Itararé foi devido as declividades dos perfis de cada um dos setores (Tabela 4). É possível observar nos resultados de Itararé que, assim como em Santos, quanto maior a declividade do perfil, maior o sobrelevação ${ }_{\text {onda }}$, resultando em maior 
sobrelevação $\mathrm{o}_{\text {total }}$ e aumentando as chances de sobrelavagem.

Tabela 4: Setores de Itararé usados na análise da sobrelavagem e suas respectivas declividades.

\begin{tabular}{|l|l|l|l|}
\hline setor & 1 & 2 & 3 \\
\hline Declividade & $0.68^{\circ}$ & $0.68^{\circ}$ & $0.51^{\circ}$ \\
\hline
\end{tabular}

Os setores 1 e 2 apresentam a mesma declividade de perfil e nesses dois setores observa-se

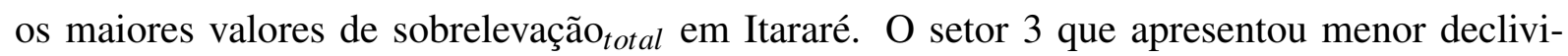
dade apresenta menores valores de sobrelevação ${ }_{\text {total }}$, assim pode-se afirmar que este setor é o que apresenta menor probabilidade de sofre sobrelavagem em casos de eventos extremos. A topografia do setor 3 permite uma maior proteção da avenida, devido a extensa faixa de areia, que em adição à menor declividade, além de ser protegida pela Ilha Urubuqueçaba. Apesar de também ter proteção de uma ilha (Porchat) o setor 1 se comportou da mesma forma que o setor 2, apresentando os mesmos resultados de sobrelevação ${ }_{\text {total }}$. Estes dois setores são os mais vulneráveis as tempestades em Itararé, apresentando maiores chances de sobrelavagem.

Nos setores de Santos além das declividades dos perfis de cada um dos setores, a altura do muro variante para os respectivos perfis influenciaram os resultados (Tabela 5). Os setores 1 e 2 de Santos apresentam menor declividade e maior extensão de faixa de areia e portanto resultou em níveis de sobrelevação ${ }_{\text {total }}$ menores. Os setores 3, 4 e 5 apresentam maior declividade do perfil e são exatamente os setores em que foram obtidos os maiores valores de sobrelevação total $_{\text {. }}$.

Tabela 5: Setores de Santos usados na análise da sobrelavagem e suas respectivas alturas de muro e declividades

\begin{tabular}{|l|l|l|l|l|l|}
\hline setor & 1 & 2 & 3 & 4 & 5 \\
\hline Muro & $2.4 \mathrm{~m}$ & $2.1 \mathrm{~m}$ & $2.2 \mathrm{~m}$ & $2.1 \mathrm{~m}$ & $2.3 \mathrm{~m}$ \\
\hline Declividade & $0.63^{\circ}$ & $0.45^{\circ}$ & $0.80^{\circ}$ & $0.85^{\circ}$ & $0.97^{\circ}$ \\
\hline
\end{tabular}

O setor 1 de Santos apresentou menos sobrelavagem que o setor 2, menos inclinado, apesar de ter resultado em valores de sobrelevação ${ }_{\text {total }}$ maiores no setor 1 do que no setor 2 . Isso se deu ao fato do muro do calçadão ter 30 centímetros a mais no primeiro setor que no segundo. $\mathrm{O}$ mesmo observa-se nos resultados do setor 5 , mais inclinado que o setor 4 , este também possui um muro 20 centímetros mais alto que o anterior protegendo a avenida de valores mais elevados de sobrelevação ${ }_{\text {total }}$. Assim, mais casos de sobrelavagem são esperados no setor 4 .

Esses resultados permitem afirmar que os setores mais a leste da praia de Santos são os que possuem maior probabilidade de sofrerem sobrelavagem em casos de eventos extremos, principalmente os setores 4 e 5, que apresentam maior declividade. A topografia da praia nos setores 1 e 2 permite uma maior proteção da avenida aos eventos de tempestade, mas também podem sofrer a sobrelavagem em caso da combinação de ondas extremas com maré meteorológica extrema. 
Apesar de Itararé apresentar uma praia com grande faixa de areia, a declividade dos setores 1 e 2 é maior do que a vista no setor 2 de Santos e próxima a do setor 1 . A declividade e o altura do muro de $2.2 \mathrm{~m}$ em Itararé explica porque alguns cenários a mais apresentam sobrelavagem nestes setores de Itararé do que na porção oeste de Santos. Levando em consideração a probabilidade de ocorrer os cenários que causariam inundação nesses setores é baixa, pode-se constatar que o trecho leste de Santos é o mais vulnerável de ambas as praias.

Os resultados não só nos permitem verificar quais as porções da praia são mais vulneráveis à sobrelavagem, mas também os cenários mais propícios a causar a inundação. Como vimos nos métodos vários cenários de onda foram usados para o cálculo do sobrelevação ${ }_{\text {onda }}\left(\mathrm{R}_{2} \%, \mathrm{R}_{37 \%}\right.$ e $\mathrm{R}_{99 \%}$ ), que foi associado a 5 cenários de maré meteorológica em maré de quadratura e sizígia. De acordo com a ocorrência de cada um desses eventos, conclui-se que os cenários menos extremos (maré meteorológica de $0 \mathrm{~m}$, Hs entre $1 \mathrm{~m}$ e $2.5 \mathrm{~m}$, Tp de $8 \mathrm{~s}$ e Maré meteorológica de e $0.5 \mathrm{~m}$, Hs entre $1 \mathrm{~m}$ e $2 \mathrm{~m}$, Tp de $8 \mathrm{~s}$ ) são os que têm maior probabilidade de ocorrer. Estes cenários só apresentam sobrelavagem nos casos calculados com maré de sizígia, sendo mais frequente no $\mathrm{R}_{37 \%}$ e no $\mathrm{R}_{99 \%}$, principalmente nos setores 4 e 5 de Santos. O restante dos cenários apresentam baixa probabilidade de ocorrência e esta diminui quanto mais extremo for o cenários. Portanto, os cenários com altos valor de Hs e maré meteorológica que indicam sobrelavagem mesmo em maré de quadratura, tem pouca chance de ocorrer.

Os casos com sobrelevação ${ }_{\text {onda }}$ de $37 \%$ e $99 \%$, consideram que esta porcentagem das ondas apresenta a altura de onda definida para os cenários, sendo assim, quando mais ondas atingindo a costa com a alto valor Hs maior será o sobrelevação ${ }_{\text {onda }}$ calculado. Com isso, pode-se observar que haverá maior valor de sobrelevação ${ }_{\text {total }}$, aumentando a chance de sobrelavagem na costa. Portando os cenários com de $\mathrm{R}_{37 \%}$ e $\mathrm{R}_{99 \%}$, apresentam maior risco de inundação.

Conforme esperado os cenários em sizígia mostram sobrelevação ${ }_{\text {total }}$ maior do que em quadratura, indicando que em época de maré de sizígia a probabilidade de sobrelavagem do calçadão será maior do que em caso de quadratura. Sugere-se que nesse período haja uma maior atenção à previsão de ondas e nível do mar, para que se possa prepara a cidade para eventual inundação costeira.

O pior cenário para ambas as praias, seria a combinação de ondas extremas, alta maré meteorológica em sizígia como aconteceu em agosto de 2016. Nesse evento específico encontra-se valores de $4.05 \mathrm{~m}$ de altura significativa e $9 \mathrm{~s}$ de período de pico, de acordo com os resultados, independente da maré meteorológica, em sizígia ocorreria a sobrelavagem em todos os setores de Santos e Itararé. 


\section{Considerações Finais e Conclusão}

\subsection{Considerações Finais}

Na análise conjunta dos resultados dos capítulos de morfodinâmica e sobrelavagem pode-se relacionar alguns fatores que contribuem para vulnerabilidade das praias à erosão e sobrelavagem. Avaliando a praia de Santos e de Itararé quanto a morfodinâmica, concluímos que a praia de Itararé como um todo e o trecho oeste da praia da Santos são mais estáveis e resistentes à ação de enventos energéticos, por possuírem características morfológicas semelhantes. Esses trechos possuem a faixa de areia mais larga e perfil praial com baixa declividade, características que permitem que a praia esteja naturalmente menos suscetível a perda de sedimento. Essas também são as características que permitem que praia esteja mais protegida a sobrelavagem.

Além da altura do muro de proteção, as características morfológicas influenciam diretamente na altura do sobrelevação ${ }_{\text {onda }}$. Quanto menor a declividade da praia mais a onda irá se dissipar e perder energia, atingindo uma menor altura na praia. Adicionalmente, a extensão da faixa de areia também controla até onde o sobrelevação ${ }_{\text {onda }}$ da onde conseguirá alcançar. Sendo assim, as porções que se mostraram mais estáveis e menos erosivas no estudo da morfodinâmica foram exatamente aqueles em que vimos menor sobrelevação ${ }_{\text {total }}$ e menos sobrelavagem.

A porção leste da praia de Santos apresenta características diferentes, possui perfil praial ligeiramente mais inclinado e faixa de areia reduzida, características que geram mais chances de ocorrência da sobrelavagem, exatamente como demonstrado nos resultados. Os valores de

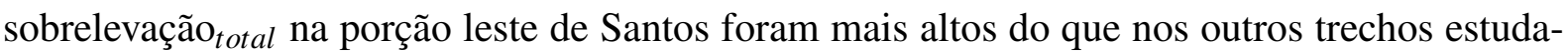
dos. O estudo morfodinâmico também indicou que este trecho da praia é menos estável e passa por constante variação de volume e apresenta pouca recuperação pós frente fria.

Os resultados de energia de onda também permitem ver por que a Ponta da Praia em Santos apresenta volume praial menor e sofre com erosão. O ponto 12, localizado no setor 5 (Ponta da Praia) de Santos, apresentou picos de força de onda maiores do que observado no setor 4, a chegada dessa onda mais energética pode estar causando maior remobilização do sedimento e, portanto, mais erosão. Este setor também apresentou altos valores de sobrelevação ${ }_{\text {total }}$ e, apesar de ser o trecho da praia com características mais sensíveis a sobrelavagem este foi o segundo setor com maior probabilidade de inundação. O setor que apresentou maior probabilidade de sofrer sobrelavagem foi o setor 4, que apresenta características semelhantes ao setor 5 mas possue altura do muro menor.

Portanto, todos os processos e características são importantes para que possa ser realizado um bom gerenciamento da zona praial. Conhecer as características morfológicas, dinâmicas e erosivas da praia permite com que se possa prever a sobrelavagem e o correto manejo da região costeira. 


\subsection{Conclusão}

Os estudos morfodinâmicos utilizando levantamentos topográficos em ambientes costeiros proporcionaram grandes avanços em estudos de respostas morfológicas aos diferentes processos atuantes, tanto naturais quanto antrópicos, nestes ambientes. O presente estudo analisou a distribuição da força de onda e dos padrões de deriva litorânea ao longo do sistema praial de Santos e Itararé, fornecendo importantes subsídios para a compreensão dos processos de erosão e morfodinâmica local. Por sua vez os levantamentos topográficos, em conjunto com a análise da sobrelavagem permitiu importantes resultados em relação a inundação da orla de ambas as praias.

- A deriva predominante para Santos foi para noroeste, com variações de intensidade ao longo dos trechos, sendo mais efetiva na porção oeste do que na porção leste.

- Os gradientes positivos e negativos da deriva potencial observados em Santos e se refletem no padrão sedimentar encontrado na praia. Os padrões de divergência associados aos trechos com erosão costeira e os de convergência com acúmulo sedimentar.

- A deriva predominante para Itararé foi para leste no trecho oeste e noroeste no trecho leste, gerando uma convergência no centro do arco praial com variações de intensidade ao longo dos trechos, sendo mais efetiva na nos extremos da praia.

- A força de onda mostrou uma distribuição na costa onde a praia de Itararé e a porção oeste da praia de Santos apresentaram os maiores valores, enquanto que há um pico mais intenso na Ponta da praia, a porção leste no geral apresentou menores valores.

- A distribuição volumétrica normalizada mostra que os setores 1, 2 e 3 de Santos possuem maior quantidade de sedimento, enquanto que os setores 4 e 5 mostram-se com os menores valores.

- A topografia de Santos indicou que os trechos com menor faixa de areia apresentam maior declividade, portanto tendências intermediárias, sendo os trechos com maior variação de volume e mais propício a erosão. A porção mais leste da praia apresentou estas características, incluindo a Ponta da Praia.

- A Ponta da Praia apresentou a maior variação e perda de volume de sedimento, corroborando com o resultado de força de onda, que indica a chega de uma onda mais intensa nesse trecho justificando a erosão vista no setor 5.

- A distribuição volumétrica normalizada em Itararé mostra que os setores 1, 2 e 3 possuem quantidade de sedimento semelhante, não indicando ocorrência de erosão em nenhum dos setores. As maiores variações de volume acorrem no setor 3 devido a transformação das ondas ao encontrar a Ilha Urubuqueçaba. 
- Os maiores valores de sobrelevação ${ }_{t o t a l}$ ocorrem nos trechos praiais com menor faixa de areia e maior declividade. Portanto os setores 4 e 5 de Santos apresentam maior probabilidade de sofrer sobrelavagem.

- Os setores 1 e 2 de Santos e a praia de Itararé toda tem menos chances de sofrer sobrelavagem por apresentarem faixa de areia extensa e menor declividade de perfil.

- Em condições de maré de sizígia a probabilidade de ocorrer sobrelavagem é maior. Os cenários com ondas acima de $3 \mathrm{~m}$, tem maior chances de causa sobrelavagem, assim como os cenários com maré meteorológica acima de $1 \mathrm{~m}$.

\section{Limitações do trabalho}

As limitações do presente trabalho encontram-se na quantidade e resolução dos dados obtidos, como:

- Os levantamento topográficos foram realizados em diferentes condições de maré, não sendo possível coletar dados na maior superfície possível, que seria na mínima maré de sizígia, evitando eliminação de dados na comparação espacial dos levantamentos;

- Falta de informação sobre a realimentação da praia e o constante realocamento do sedimento realizado pela prefeitura;

- Impossibilidade da validação do modelo de ondas em função da ausência de dados de ondas medidos próximo à praia;

- Ausência de dados da altura do muro do calçadão de Itararé. 


\section{Referências}

Ab’Saber, Aziz Nacib. 1969. Ritmo da epirogênese pós-cretácica e setores das superfícies neogênicas em São Paulo. Universidade de São Paulo, Instituto de Geografia.

Almeida, Fernando de FM, Yociteru Hasui, e Benjamim Bley de Brito Neves. 1976. "The upper precambrian of South America." Boletim IG 7:45-80.

Bittencourt, Abílio Carlos da Silva Pinto, José Maria Landim Dominguez, Louis Martin, e Iracema Reimão Silva. 2005. "Longshore transport on the northeastern Brazilian coast and implications to the location of large scale accumulative and erosive zones: An overview." Marine Geology 219 (4): 219-234.

Bittencourt, Abílio CSP, Louis Martin, José ML Dominguez, Iracema R Silva, e Daiana L Sousa. 2002. "A significant longshore transport divergence zone at the Northeastern Brazilian coast: implications on coastal Quaternary evolution.” Anais da Academia Brasileira de Ciências 74 (3): 505-518.

Bonduki, Nabil Georges. 1996. "Habitat: as práticas bem-sucedidas em habitaçäo, meio ambiente e gestäo urbana nas cidades brasileiras.” In Habitat: as práticas bem-sucedidas em habitaçäo, meio ambiente e gestäo urbana nas cidades brasileiras.

Caires, S, A Sterl, JR Bidlot, N Graham, e V Swail. 2004. "Intercomparison of different wind-wave reanalyses." Journal of Climate 17 (10): 1893-1913.

Calliari, Lauro Júlio, Dieter Muehc, Fernanda Gemael Hoefel, e Elírio Toldo Jr. 2003. "Morfodinâmica praial: uma breve revisão.” Revista brasileira de oceanografia 51 (unico): 63-78.

Campos, R.M., R.D.E. Camargo, e E.J. Harari. 2010. “Caracterização de eventos extremos do nível do mar em Santos e sua correspondência com as reanálises do modelo do NCEP no sudoestre do Atlântico Sul.” Revista Brasileira de Meteorologia 25:175-184.

Cassiano, Gabriela Freire, R. B. Ribeiro, e E. A. Yassuda. 2012. “Acquisition of wave data and modeling in Santos Bay, São Paulo, Brazil." Proceedings of the 10th International Conference on Hydroscience \& Engineering.

Cassiano, Gabriela Freire, e Eduardo Siegle. 2010. "Migração lateral da desembocadura do Rio Itapocú, SC, Brasil: evolução morfológica e condicionantes físicas." Revista Brasileira de Geofísica 28 (4): 537-549.

Davies, John Lloyd. 1980. Geographical variation in coastal development. Volume 4. Longman Publishing Group.

Davis, RA, e DM FitzGerald. 2004. Beaches and Coasts. Massachusetts: Blackwell.

Deltares. 2011. User Manual Delft3D-Wave. Simulation of shot-crested waves with SWAN. Deltares. 
Donnelly, Chantal, Nicholas C Kraus, e Magnus Larson. 2004. "Coastal Overwash: Part 1, Overview of Processes.” Technical Report, ENGINEER RESEARCH AND DEVELOPMENT CENTER VICKSBURG MS COASTAL AND HYDRAULICS LAB.

Elliff, C.I., N.S. Motta, I.M. Scricco, e M.O. Barros. 2013. "Classificação Morfodinâmica da Praia do Gonzaga, Santos, São Paulo, Brasil.” Caderno de Geociências 10:133-138.

Farinnaccio, A., S. C. Goya, e M. G. Tessler. 2009. "Variações da linha de costa nas baías de Santos e São Vicente." Quaternary and Environmental Geosciences 1, no. 1.

Ferreira, Oscar, Tiago Garcia, Ana Matias, Rui Taborda, e J Alveirinho Dias. 2006. "An integrated method for the determination of set-back lines for coastal erosion hazards on sandy shores." Continental shelf research 26 (9): 1030-1044.

Fukumoto, Marina Midori. 2003. "Caracterização da sedimentação atual e reconstituição da história deposicional recente na Baía de Santos, a partir das características composicionais e isotópicas da matéria orgânica." Ph.D. diss.

Fúlfaro, VJ, e WL Ponçano. 1976. "Sedimentação atual do estuário e baía de Santos: um modelo geológico aplicado a projetos de expansão da zona portuária." Congresso Brasileiro De Geologia E Engenharia, Volume 1. 67-90.

Gagliardi, Marcelo Henrique. 2013. "Análise de riscos costeiros a eventos atmosféricos extremos no litoral sul do Estado de São Paulo-estudo de caso na região da desembocadura de Cananéia.” Ph.D. diss., Universidade de São Paulo.

Garrity, Nicholas J, Robert Battalio, Peter J Hawkes, e Dan Roupe. 2006. "Evaluation of event and response approaches to estimate the 100-year coastal flood for Pacific coast sheltered waters.” In Coastal Engineering 2006: (In 5 Volumes), 1651-1663. World Scientific.

Gregorio, H.P. 2009. “Modelagem Numérica da Dispersão da Pluma do Emissário Submarino de Santos.” Dissertação de Mestrado, Instituto Oceanográfico. Universidade de São Paulo.

Harari, Joseph, e Ricardo de Camargo. 1998. "Modelagem numérica da região costeira de Santos (SP): circulação de maré.” Revista Brasileira de Oceanografia 46 (2): 135-156.

Healy, T, e RG Dean. 2000. Methodology for delineation of coastal hazard zone and development setback for open duned coasts, chapter 19 in JB Herbich (editor) Handbook of Coastal and Ocean Engineering.

Holthuijsen, Leo H. 2007. Waves in oceanic and coastal waters. Cambridge university press. IBGE. 2010. Instituto Brasileiro de Geografia e Estatística - Censo demográfico 2010 - Santos. 2016. Instituto Brasileiro de Geografia e Estatística - Modelo de ondulação geoidal.

Italiani, D.M. 2014. "Resposta morfodinâmica à alimentação artificial da Ponta da Praia, Santos, SP.” Dissertação de Mestrado, Instituto Oceanográfico. Universidade de São Paulo.

King, C. A. M. 1972. "Beaches and coasts: London.” Edward Arnold, 570p. 
Komar, P. D. 1998. "Beach processes and sedimentation."

Lemos, CF, e NO Calbete. 1996. "Sistemas Frontais que atuaram no Brasil de 1987 a 1995." Climanálise, Ed. Especial Comemorativa, vol. 10.

Linham, Matthew M, e Robert J Nicholls. 2010. “Technologies for Climate Change Adaptation."

Longuet-Higgins, Michael S. 1970. "Longshore currents generated by obliquely incident sea waves: 1." Journal of geophysical research 75 (33): 6778-6789.

Magini, C., J. Harari, e D.M.S. Abessa. 2007. “Circulação recente de sedimentos costeiros nas praias de Santos durante eventos de tempestade: dados para gestão de impactos físicos costeiro." Geociências 26:349-355.

Martins, C.C. 2006. "Morfodinâmica de praia refletiva: estudo de caso na Praia do Sununga, litoral norte do Estado de São Paulo.” Tese de Doutorado, Instituto Oceanográfico. Universidade de São Paulo.

Mase, Hajime. 1989. "Random wave runup height on gentle slope." Journal of Waterway, Port, Coastal, and Ocean Engineering 115 (5): 649-661.

Mase, Hajime, Takashi Tamada, Tomohiro Yasuda, Terence S Hedges, e Maria T Reis. 2013. "Wave runup and overtopping at seawalls built on land and in very shallow water." Journal of waterway, port, coastal, and ocean engineering 139 (5): 346-357.

Muehe, D. 2001. "Critérios morfodinâmicos para o estabelecimento de limites da orla costeira para fins de gerenciamento." Revista Brasileira de Geomorfologia, vol. 2.

Nielsen, Peter, e David J Hanslow. 1991. "Wave runup distributions on natural beaches." Journal of Coastal Research, pp. 1139-1152.

Pianca, C., P.L.F. Mazzini, e E. Siegle. 2010. "Brazilian offshore wave climate based on NWW3 reanalysis.” Brazilian Journal of Oceanography 58(1):53-70.

Ponçano, Waldir Lopes. 1985. "Sedimentação atual aplicada a portos no Brasil." Ph.D. diss., Universidade de São Paulo.

Pullen, T, NWH Allsop, T Bruce, A Kortenhaus, H Sch, JW Van der Meer, et al. 2007. "Wave overtopping of sea defences and related structures: assessment manual."

Raposeiro, Paulo Duarte, Conceição Juana Fortes, Rui Capitão, Maria Teresa Reis, José Carlos Ferreira, Maria Teresa Sá Pereira, e José Guerreiro. 2013. "Preliminary phases of the HIDRALERTA system: Assessment of the flood levels at S. João da Caparica beach, Portugal." Journal of Coastal Research 65 (sp1): 808-813.

Reboita, Michelle Simões, Nisia Krusche, Tércio Ambrizzi, e Rosmeri Porfírio da Rocha. 2012. "Entendendo o Tempo e o Clima na América do Sul." Terrae Didatica 8 (1): 34-50. 
Regnauld, Hervé, Paolo A Pirazzoli, Gwenolée Morvan, e Mylene Ruz. 2004. "Impacts of storms and evolution of the coastline in western France." Marine Geology 210 (1-4): 325337.

Rocha, A.C. 2003. "Aplicação de métodos diretos e indiretos da análise de dispersão de sedimentos na baía de Santos - SP.” Tese de Doutorado, Instituto Oceanográfico. Universidade de São Paulo.

Ruggiero, Peter, Paul D Komar, William G McDougal, John J Marra, e Reggie A Beach. 2001. "Wave runup, extreme water levels and the erosion of properties backing beaches." Journal of Coastal Research, pp. 407-419.

Sallenger Jr, Asbury H. 2000. "Storm impact scale for barrier islands." Journal of Coastal Research, pp. 890-895.

Serafin, Katherine A, e Peter Ruggiero. 2014. "Simulating extreme total water levels using a time-dependent, extreme value approach.” Journal of Geophysical Research: Oceans 119 (9): 6305-6329.

Shih, Shyuer-Ming, e Paul D Komar. 1994. "Sediments, beach morphology and sea cliff erosion within an Oregon coast littoral cell.” Journal of coastal Research, pp. 144-157.

Short, Andrew D. 1978. "Wave power and beach-stages: a global model.” In Coastal Engineering 1978, 1144-1162.

. 1999. Handbook of beach and shoreface morphodynamics. Great Britain: John Wiley; ISBN 0-471-96570-7.

Siegle, Eduardo, e Nils Edvin Asp. 2007. "Wave refraction and longshore transport patterns along the southern Santa Catarina coast.” Brazilian Journal of Oceanography 55 (2): 109_ 120.

Silveira, Tanya M, Rui Taborda, Mafalda M Carapuço, César Andrade, Maria C Freitas, João F Duarte, e Norbert P Psuty. 2016. "Assessing the extreme overwash regime along an embayed urban beach." Geomorphology 274:64-77.

Sousa, PHGO. 2013. "Vulnerabilidade à erosão costeira no litoral de São Paulo: interação entre processos costeiros e atividades antrópicas.” Ph.D. diss., Tese de Doutorado. Instituto Oceanográfico da Universidade de São Paulo.

Souza, Celia Regina de Gouveia. 2009. “A EROSÃO NAS PRAIAS DO ESTADO DE SÃO PAULO: CAUSAS, CONSEQÜÊNCIAS, INDICADORES DE MONITORAMENTO E RISCO.”

Stech, J.L. e J.A. Lorenzzetti. 1992. "The response of Therapy South Brazil Bight to Therapy passage of wintertime cole front.” J. Geophysical Res. 97:9507-9520.

Stockdon, Hilary F, Rob A Holman, Peter A Howd e Asbury H Sallenger Jr. 2006. "Empirical parameterization of setup, swash, and runup." Coastal engineering 53 (7): 573-588. 
Stockdon, Hilary F, David M Thompson, Nathaniel G Plant e Joseph W Long. 2014. "Evaluation of wave runup predictions from numerical and parametric models." Coastal Engineering 92:1-11.

Stone, Gregory W e Julian D Orford. 2004. Storms and their significance in coastal morphosedimentary dynamics.

Suguio, Kenitiro e Louis Martin. 1978. "Formaçoes quaternarias marinhas do litoral paulista e sul fluminense $=$ quaternary marine formations of the state of Sao Paulo and Southern Rio de Janeiro."

Tessler, MG e MM Mahiques. 2000. "Por uma terminologia brasileira para o ambiente praial." Simpósio Brasileiro sobre praias arenosas.

Tolman, Hendrik L, Bhavani Balasubramaniyan, Lawrence D Burroughs, Dmitry V Chalikov, Yung Y Chao, Hsuan S Chen e Vera M Gerald. 2002. "Development and implementation of wind-generated ocean surface wave Modelsat NCEP." Weather and forecasting 17 (2): 311-333.

Van der Meer, Jentsje W e Cor-Jan M Stam. 1992. "Wave runup on smooth and rock slopes of coastal structures." Journal of Waterway, Port, Coastal, and Ocean Engineering 118 (5): 534-550.

Wang, Xiaolan L e Val R Swail. 2001. "Changes of extreme wave heights in Northern Hemisphere oceans and related atmospheric circulation regimes." Journal of Climate 14 (10): 2204-2221.

Wright, LD e Andrew D Short. 1984. "Morphodynamic variability of surf zones and beaches: a synthesis." Marine geology 56 (1-4): 93-118.

Zenkovich, VP. 1967. "Processes of coastal development: Oliver e Boyd." Edinburgh e London. 